SECURITY CLASSIFICATION OF THIS PAGE (Whan Dete Entored)

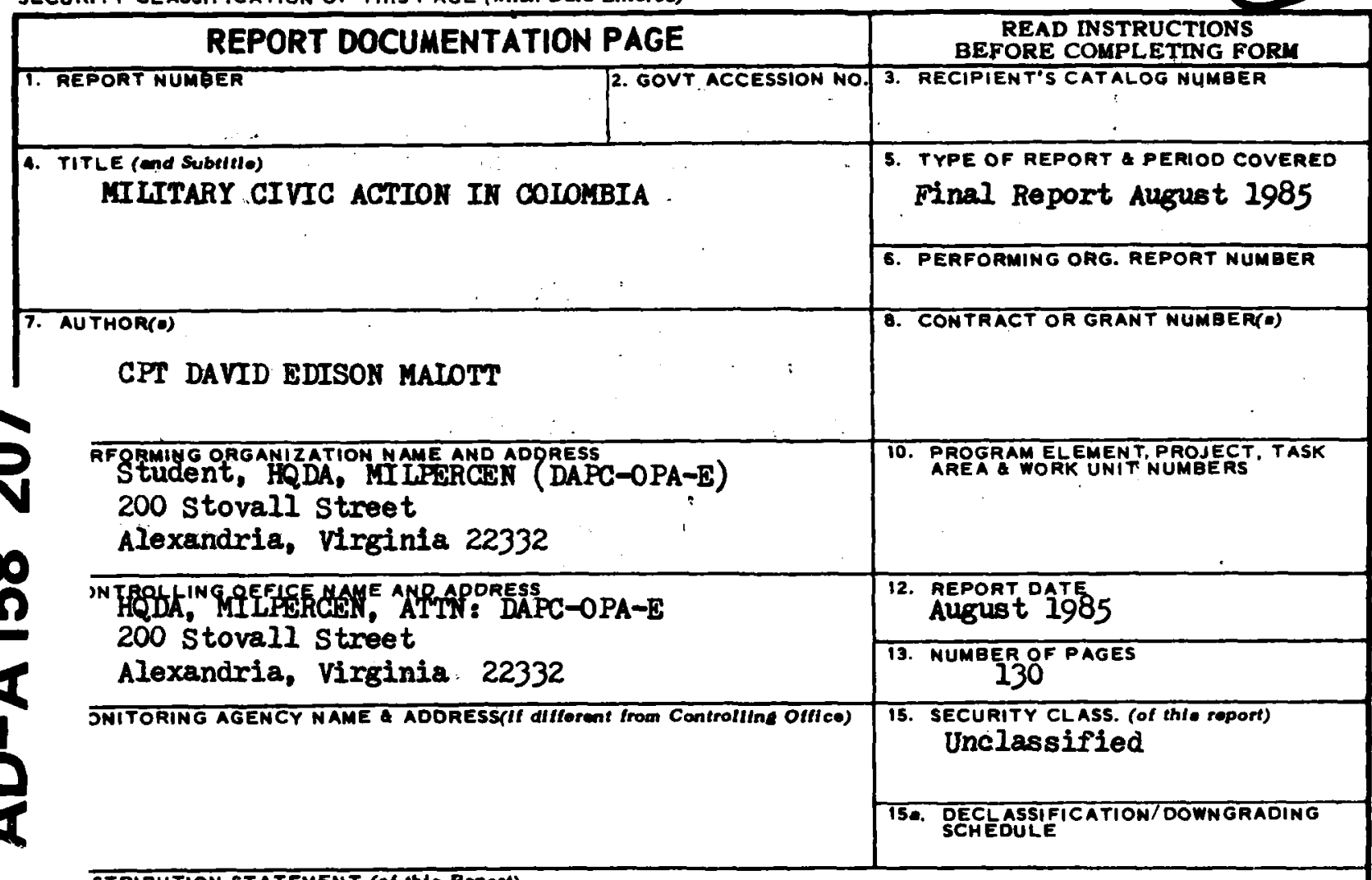

STAIBUTION STATEMENT (OI thlo Roport)

Approved for public release; distribution unlinited.

16. SUPPLEMENTARY NOTES

Master thesis, University of Florida

19. KEY WORDS (Continue on reverce olde If noceeseary and tdonttly by block number)

Civic Action, Colombia, Ia violencia, Security Assistance

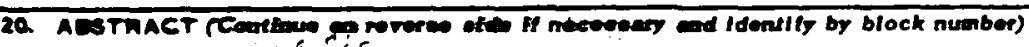

This stuafy'is an examination of the role that the colombian military's civic action programs played in assisting to reduce the level of internal violence during the domestic upheaval known as la violencia. Included in this study is a discussion of the historical development of the civic action concept, highlighting the United States' experience with the concept, as the United States included the concept as part of the foreign policy of the $1960^{\circ} \mathrm{s}$. The phenomenon known as la violencia is discussed with 


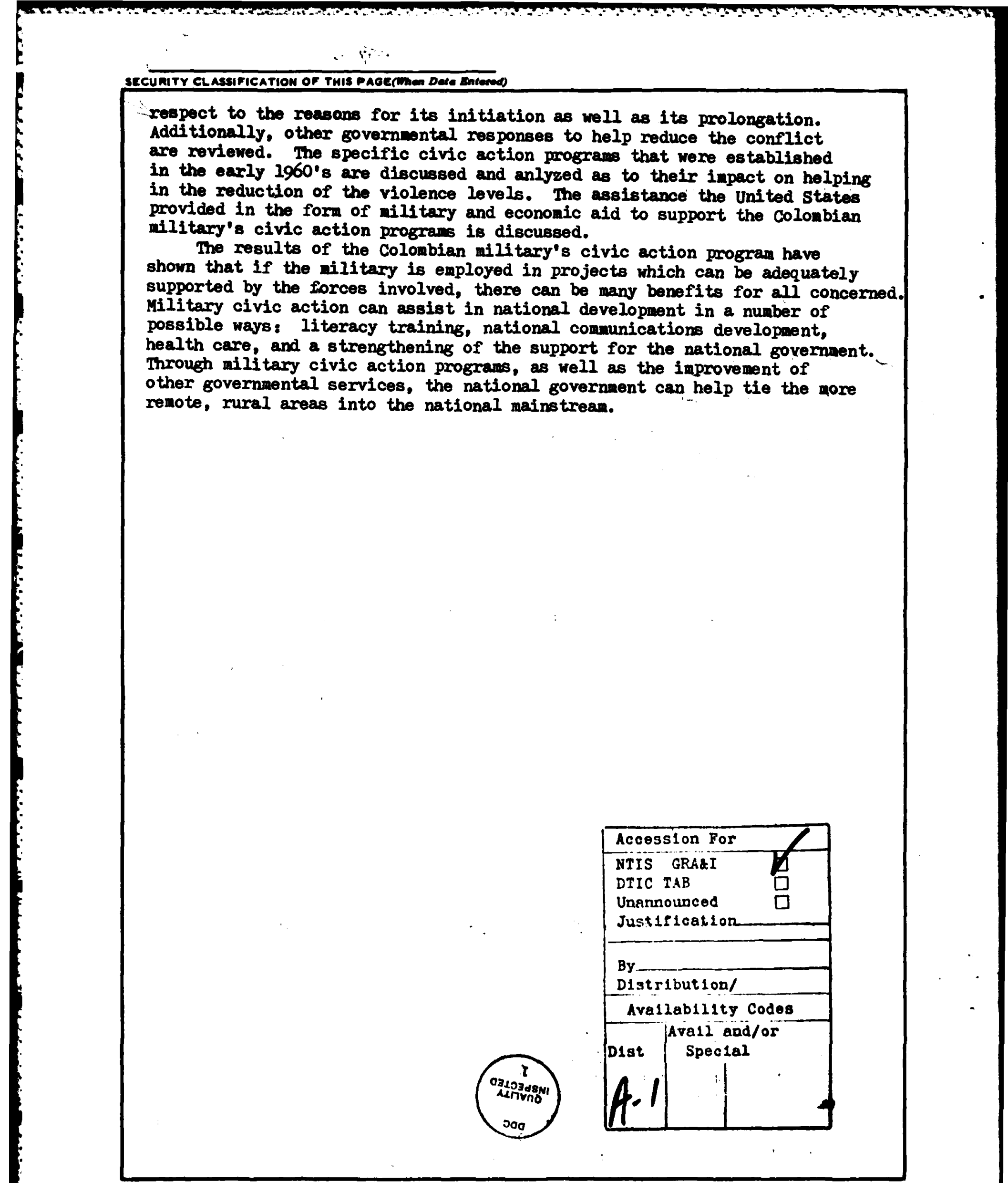

SECURITY CLASSIFICATION OF THIS PAGE(TmON Date Entored) 
MIITTARY CIVIC ACTION IN COIOMBIA

CPT DAVID EDISON MAIOTT

HQDA, MTLFERCEN (DAPC-OPA-E)

200 stovall street

Alexandria, VA 22332

Final report August 1985

Approved for public release; distribution unlinited.

A thesis submitted to the University of Florida, Gainesville, Florida, in partial fulfillment of the requirements for the degree of Master of Arts. 


\section{MILITARY CIVIC ACTION \\ IN \\ COLOMBIA}

\section{By}

DAVID EDISON MALOTT

\section{A THESIS PRESENTED TO THE GRADUATE SCHOOL \\ OF THE UNIVERSITY OF FLORIDA IN \\ PARTIAL FULFILLMENT OF THE REQUIREMENTS \\ FOR THE DEGREE OF MASTER OF ARTS}

UNIVERSITY OF FLORIDA

1985 


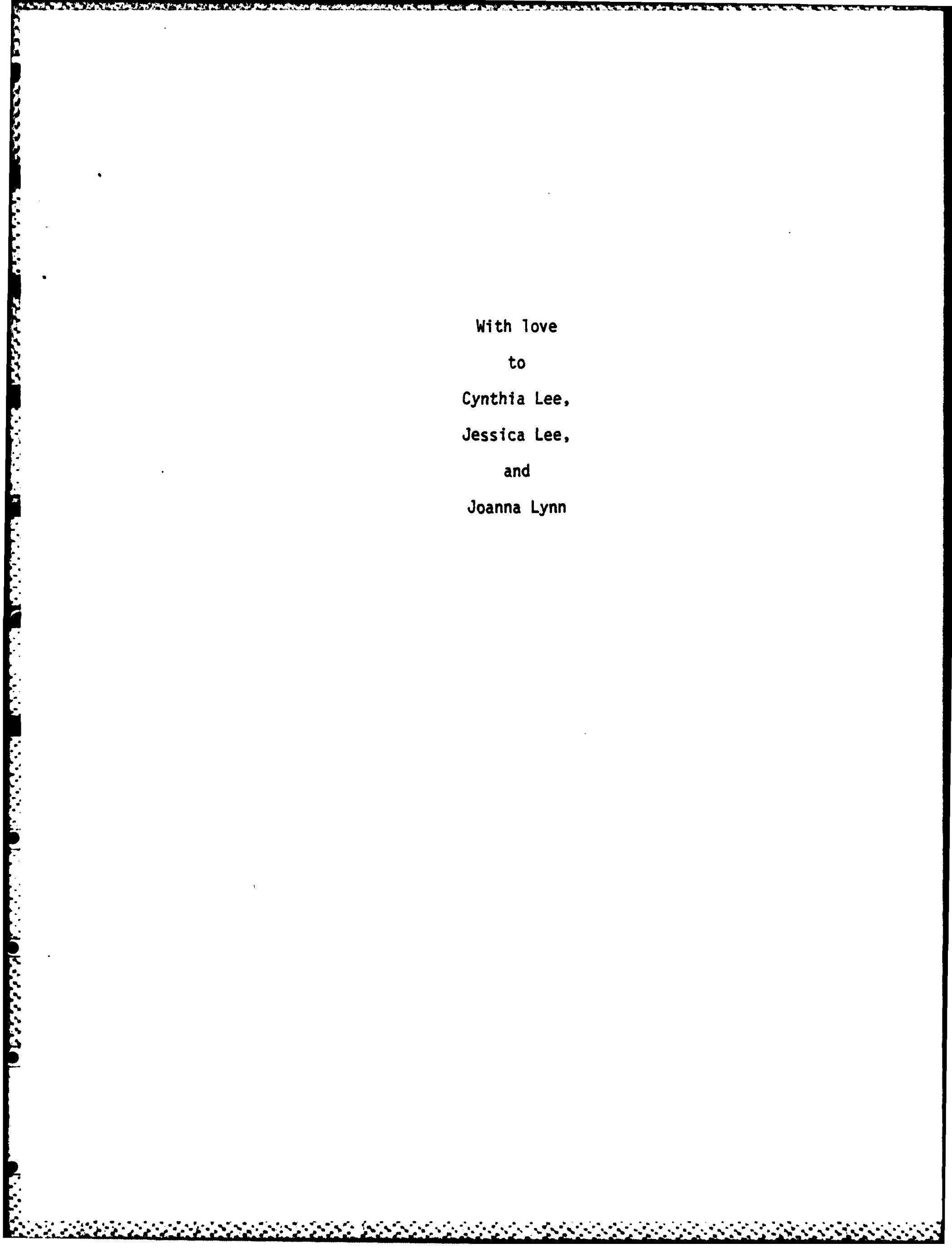


The writer wishes to express his appreciation to Prof. David Bushnell for his assistance, guidance, and encouragement in the preparation of this thesis. 
TABLE OF CONTENTS

Page

ACKNOWLEDGMENTS ..................... . . i i

ABSTRACT ....................... . . . v

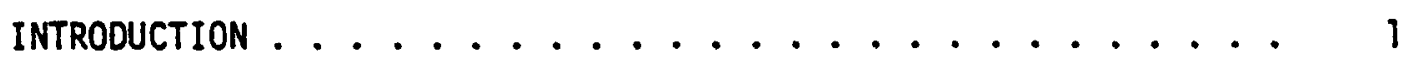

Note .................... . . 4

HISTORICAL DEVELOPMENT OF CIVIC ACTION ............ 5

Notes .................. . . 24

BACKGROUND AND DISCUSSION OF LA VIOLENCIA . . . . . . . . 27

Notes ................. . . 54

MILITARY CIVIC ACTION IN COLOMBIA . . . . . . . . . . . 59

Antecedents of U.S.-Colombian Military Cooperation . . . 63

Establishment and Development of Colombian

Military Civic Action Programs .......... 70

Notes .................. 100

THE CASE FOR MILITARY CIVIC ACTION . . . . . . . . . . 107

Notes ................... 113

BIBLIOGRAPHY ...................... . . 114

BIOGRAPHICAL SKETCH .................. 130 
Abstract of Thesis Presented to the Graduate School of the University of Florida in Partial Fulfillment of the Requirements for the Degree of Master of Arts

\author{
MILITARY CIVIC ACTION \\ IN \\ COLOMBIA
}

By

David Edison Malott

August 1985

Chairman: David Bushnell

Major Department: Latin American Studies

This study is an examination of the role that the Colombian military's civic action programs played in assisting to reduce the level of internal violence during the domestic upheaval known as la violencia. Included in this study is a discussion of the historical development of the civic action concept, highlighting the United States' experience with the concept, as the United States included the concept as part of its foreign policy in the 1960s. The phenomenon known as la violencia is discussed with respect to the reasons for its initiation as well as its prolongation. Additionally, other governmental responses to help reduce the conflict are reviewed. The specific civic action programs that were established in the early 1960s are discussed and analyzed as to their impact on helping in the reduction of the violence levels. The assistance the United States provided in the form of military and 
economic aid to support the Colombian military's civic action programs is discussed.

The results of the Colombian military's civic action program have shown that if the military is employed in projects which can be adequately supported by the forces involved, there can be many benefits for all concerned. Military civic action can assist in national development in a number of possible ways: literacy training, national communications development, health care, and a strengthening of the support for the national government. Through military civic action programs, as well as the improvement of other governmental services, the national government can help tie the more remote, rural areas into the national mainstream.

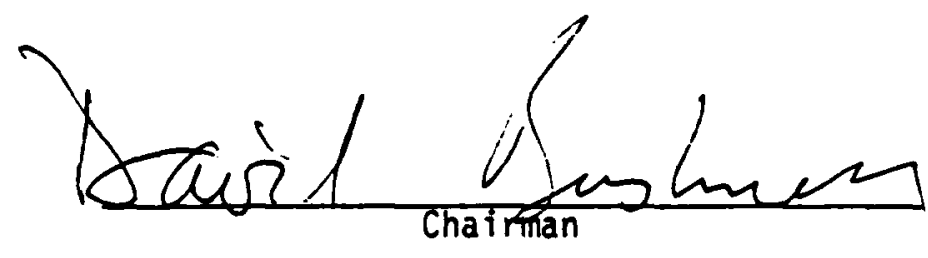




\section{INTRODUCTION}

En Colombia, que es la tierra de las cosas singulares, dan la paz los militares, y los civiles dan guerra. (In Colombia, which is the land of strange things, the soldiers bring peace, and the civilians make war.)!

This Colombian folk saying captures the essence of the objective of this study, which is an examination of the role that the Colombian military's civic action programs played in assisting to reduce the level of internal violence during the domestic upheaval known as la violencia. This study will discuss the development of the military civic action programs that were implemented in the mid-1960; and determine what were the results of the programs, and how they may have helped to reduce the level of internal violence or, in effect, bring peace to the nation. Although the study of the specific civic action programs implemented in Colombia is the central issue in this work, a wider context is required to understand these programs. Therefore, the historical development of the civic action concept will also be reviewed. The specific United States experience in civic action requires attention, as the United States made the civic action concept part of its foreign policy in dealing with developing nations in the early 1960s.

The next topic of discussion will be the phenomenon known as la violencia, with special attention to the causes of its initiation as well as the prolongation of the violence. The historical setting 
which led to the outbreak of the violence will be briefly reviewed. The various phases which the violence went through will be examined and any changes in direction or nature of the violence as well as the areas involved and governmental responses will be highlighted.

Finaliy, after the discussion of la violencia, the establishment of and the types of civic action programs that were implemented will be discussed. The assistance the United States provided in training, funds, and organizational support will be analyzed in terms of how much assistance, and what types of assistance, the United States provided to Colombia in support of civic action programs. The results of the programs will be evaluated with respect to such factors as number of people receiving health care and improvements made to the national infrastructure. Finally, the overall impact of civic action in helping to reduce the level of violence will be assessed in terms of popular support for the programs. Other indicators that will be discussed are the number of casualties due to the violence and strength of guerrilla forces by the mid-1960s.

At the same time, this study may perhaps stimulate thought on the potential uses of military forces in support of their nation's internal development. The civic action approach is opposite from what seems to be the current school of thought in many developing nations, where the military sometimes appears obsessed with the purchase of expensive and highly technical equipment that in all probability will never be required in the defense of the nation. This examination of the Colombian experience in civic action may help 
to demonstrate other important missions that the military can fulfill besides national defense, and highlight what the military can accomplish to assist in internal development. 
4

Note

$T_{\text {Robert H. Dix, Colombia: The Political Dimensions of Change }}$ (New Haven, Connecticut: Yale University Press, 1967), p. 299. 


\section{HISTORICAL DEVELOPMENT OF CIVIC ACTION}

Military civic action, though employed on numerous occasions throughout history, is a concept whose meaning is often not fully understood by those who use it, or by those who observe the results. The definition of military civic action according to the United States military is

The use of preponderantly indigenous military forces on projects useful to the local population at all levels in such fields as education, training, public works, agriculture, transportation, communications, health, sanitation, and others contributing to economic and social development, which would also serve to improve the standing of the military with the population. 1

A somewhat more detailed and eloquent definition is the one provided by Lieutenant General Alberto Ruiz Novoa, who as the Colambian Minister of War oversaw the establishment and operation of civic action programs in Colombia in the early 1960s. Lieutenant General Ruiz Novoa defined military civic action as

- . having as its purpose to extend to vast sectors of the populace the government's help, especially in the field of social assistance, through the military organization of the nation. It is based on the premise that the use of military means to accomplish programs of economic and social welfare will awaken in the benefited population trust and sympathy towards the government and the military forces. These programs are developed without affecting military efficiency of the armed institutions or compromising their principal functions.

Besides accomplishing an effective program of assistance to the people, military civic action gains the support of the 
populace for the legitimate and rightful regime and for its armed forces. It also helps to prove the usefulness of the army and to counter the attacks of those who see in military expenditures only a useless drain on public funds, and who deny the importance of the missions of the armed forces within the state.

Besides reaching the objective of counteracting the campaigns of the communists among the people against the armed institutions, civic action makes known the concern of the government for the less favored and stops those who foster insurrection, by proving that welfare and social improvement can come to the people in a legal and orderly manner.?

Finally, Prof. Lyle N. McAlister offers a view of what civic action is, which is both succinct and very descriptive. According to Prof. MCAlister, "civic action programs involve, first, education of army personnel in civic responsibility, and, second, the cooperative participation of army units in various community development projects-education, health, transportation, communication, agriculture, and the like." 3 While these definitions vary somewhat in content, all agree as to the essence of what composes civic action. Specifically, military forces of a nation are employed to assist in the internal development of the nation, and provide a resource which the national government can muster to aid in its development plans.

The concept of military civic action was far from being a new or revolutionary idea when the United States formally adopted it in the 1960s as a foreign policy initiative to assist developing nations. The use of military forces to assist in the development of a nation's infrastructure is as old as organized armies. However, if one tried to determine the point of origin a reasonable choice could be Israel, as in 444 B.C., under the leadership of Nehemiah, the Wall of Jerusalem 
was rebuilt using military forces. Nehemiah instructed his soldiers "to work as masons and laborers with weapons within easy reach beside them, or belted to their sides." 4 It was under the Romans, however, that the concept of civic action by the military spread on a wide scale with the growth of the empire, as new lands were colonized and infrastructures built. The concept of civic action appeared in the New World even before the arrival of the Europeans, as the Incan army constructed roads and irrigation systems in Peru. 5 Therefore, it had been present in various nations of the world long before the United States' first use of civic action to assist in its own development, to say nothing of its exporting of the concept in the 1960 s.

The United States represents a relatively recent example of a nation employing its military to assist in its internal development, even though the United States Army has been engaged in civic-action type projects aimost since its establishment. The importance of the role the army played in nation-building for the United States cannot be overstated. Colonel T. M. Ashton, United States Air Force, in a speech before the Inter-American Defense College in Washington, O.C., on 29 January 1963, stated that:

It would be difficult to exaggerate the role of the soldier in the development and growth of the United States. If statistics were available, they might well show that the contribution to the economy of this nation from civic action type projects in which the United States Army has participated exceeds the cost of maintaining United States forces throughout our history. 6

Of course, this speech occurred during the drive for "export" of the civic action concept in developing nations and was a frank attempt to 
demonstrate what a nation's military can accomplish in the way of national development. What is clear, though, is that the army did play a key and continuous role in the United States' effort in nation-butlding.

This experience began as early as 1794 , when General George Washington formed an engineer corps at West Point, New York, to assist in the training of officers. This led to the establishment of the Military Academy in 1802, which followed French examples of schooling and training and placed importance on engineering subjects in the curriculum. ${ }^{7}$ The Military Academy remained the only technical engineering school in the nation until 1824, when the first civilian school was established. As further schools were established, graduates of the Military Academy were used to fill the growing number of required engineering faculty positions. 8

In addition to providing trained engineers that the nation badly needed, the army played a more valuable civic action role by its contribution to the westward expansion. Army explorations of the West were begun after the Louisiana Purchase in 1803. Expeditions led by army officers Captain Meriwether Lewis and Lieutenant William Clark (1804-1806) and by Lieutenant Zebulon Pike (1805-1807) paved the way by surveying and mapping from the Mississippi River to the Pacific Ocean. These initial explorations were later followed by expeditions led by Captain Benjamin Bonneville, who explored the Rocky Mountains (1832-1835), and Lieutenant John C. Fremont, who explored and surveyed routes into the Oregon Territory and California $(1841-1844) .^{9}$ 
Therefore, the United States at a very early state in its history made use of its own military in civic action projects. However, to state that the army was simply used as explorers and nothing else would be in error. as it fulfilled other important roles in the nation-building process.

Other projects for which the army was assigned responsibility cover the gamut of activities that civilian agencies might have controlled. First, after the War of 1812, the Secretary of War John $C$. Calhoun assigned army surgeons the task of maintaining day-to-day weather records, which would later be used in the first scientific weather study in the United States. ${ }^{10}$ Secondly, in 1816 the Army Corps of Engineers was assigned responsibility for internal navigation and flood control of the nation's waterways. Also, it was army personnel who constructed the so-called "Chicago Road" across southern Michigan in 1825. Army officers were frequently loaned to private railroad companies as well as state governments between 1815 and the 1860s as a means to assist in developing cormunication networks which were then being built. 11 Indeed, the army was called upon to assist in the construction of public works projects throughout the nation in the nineteenth century. Clearly, the United States Army played a valuable role in the nation's development due to the civic action programs that were undertaken and completed.

The first true example of the United States employing the civic action concept outside the nation came as a result of the MexicanAmerican War (1846-1848). The United States commander, General 
Winfield Scott, conducted civic action programs during the period from the fall of Chapultepec in September 1847 to the Treaty of Guadalupe Hidalgo in February 1848. Although this was a relatively short period, General Scott took prompt: health care measures, supported the social agencies of the Church and encouraged the reopening of educational institutions. 12 With the removal of United States forces from Mexico, the United States would not employ the civic action concept outside the nation again until the turn of the century.

The United States utilized the civic action concept in the aftermath of the Spanish-American War. In the Philippines, the United States was confronted with the task of governing and modernizing a former Spanish colony as well as being faced with combatting a guerrilla insurgency. The guerrillas were comprised of filipinos who aspired to national independence and were led by Emilio Aguinaldo. Additionally, United States forces were opposed by the Moro Indians on the island of Mindanao who feared interference with their religious practices and also waged a guerrilla war. ${ }^{13}$ As a means to assist in ending the guerrilla warfare, the United States undertook a large-scale program of economic development and nation-building that was comprised of the following: the construction of educational centers, road building, medical and health improvements, and improved governmental administration. ${ }^{14}$ This program of civic action greatly benefited the populace and helped end the guerrilla warfare. After the experience of the United States forces in the Philippines, the civic action concept would become an informal segment of United States foreign policy, especially in regard to 
Latin America in the early part of the twentieth century. However, while the United States did make use of civic action type programs in the area during this period, almost all the projects were conducted strictly by United States forces that were in fact occupying various Latin American nations. The United States Marines occupied Haiti (1915-1934), the Dominican Republic (1916-1924), and Nicaragua (1912-1925, 1927-1933); and other United States forces maintained brief occupations of Panama and Cuba. ${ }^{15}$ While civic action projects were conducted in these nations, the indigenous military forces were not the primary force for them, as they were basically non-existent or only recently organized. Indeed the United States Marines helped to establish and train military forces in those countries which were occupied. But those newly formed forces, while paying lip service to the objectives of civic action, were in fact subordinated to or used as regime protectors by dictators such as Anastasio Somoza and Rafael Trujillo.

After World War II, the United States again had major commitments in developing nations which might benefit from civic action programs. Two nations in particular became milestones for the United States in this regard. These were the Philippines and Korea. The civic action program that was used in the Philippines was the first example of a successful civic action program in the twentieth century to combat an internal rebellion. What is important in this case was that the indigenous government forces played the central role in the civic action programs and not United States forces. This 
marked a major change from the previous civic action experience of the United States, as the Minister of War, Ramon Magsaysay, organized and led the civic action program against the Communist-led Huk rebellion. 16

By 1950 the Huk movement was becoming a serious threat to the stability of the national government. The Huks recruited the majority of their support from tenant farmers who were being exploited by land-owners. Moreover, the military was wi thout support from the populace as it was largely undisciplined in its treatment of the people. Magsaysay, however, used army lawyers to aid in handling the legal problems of disgruntled farmers who were being forced from their lands, and he established the Economic Development Corps (EDCOR) which helped to secure unused land for those who had lost their farms. ${ }^{17}$ Under the EDCOR program, former guerrillas along with needy civilians were resettled in new communities in Mindanao with government assistance. The civic action program conducted by the Philippine government helped to end the Huk rebellion. ${ }^{18}$

South Korea was the other nation which had need for some type of civic action programs during this period. The nation required assistance to rebuild at the conclusion of the Korean conflict in 1953, and the programs which the United States helped to establish in Korea were the first large-scale United States-supported civic action programs in the post-World War II era. They began on a relatively low level in the form of voluntary technical assistance provided by United States military personnel to Koreans to aid in the national 
reconstruction. Then, as the involvement of United States forces grew, General Maxwell D. Taylor, commander of the United States Eighth Army, submitted a proposal in August 1953 that outlined the possibilities of a civic action program in Korea. This proposal was sent to Assistant Secretary of Defense John A. Hannah who then submitted it to President Eisenhower. ${ }^{19}$

The plan in question requested $\$ 15$ million worth of construction materials to aid in the building of public facilities. President Eisenhower approved the plan and included an authorization to "utilize the surplus materials in ways that would be of most benefit to the people of Korea." 20 what emerged was the Armed Forces Assistance to Korea (AFAK) program. This program was formally approved in November 1953 by Congress, which allocated $\$ 20$ million for its support. A set of priorities among the planned projects was also established: (1) schools, (2) public health facilities, (3) orphanages, (4) civic butldings, (5) public utilities, and (6) bridges. ${ }^{21}$ By the end of 1955, AFAK had completed 2,914 construction projects, with an estimated value to the Korean economy in excess of $\$ 48$ million. 22

Within the Americas, meanwhile, the 1950s saw a shift in United States policy from the concept of hemispheric defense to one which highlighted internal security. The Mutual Security Act of 1951 had been established as a means to provide United States military assistance to Latin American nations if they would participate with the United States in the defense of the hemisphere. By 1959, the 
act had led the United States to establish bilateral executive agreements with thirteen Latin American nations. The United States provided military assistance to these nations in order to create a system of collective security against a perceived Communist threat; to reduce the number of United States forces required to defend the area by spreading the defense requirements among the Latin American nations; and to maintain access to strategic shipping locations, such as the Panama Canal and the Strait of Magellan. 23 The strategy of hemispheric defense would be altered by the end of the decade, however, primarily as a result of the assumption of power by Fidel Castro in Cuba in 1959. The perceived threat to the hemisphere was now not overt Soviet aggression, but rather subversion through developing internal insurgencies. 24

While Castro's Revolution was a significant turning point in the modern history of the Western Hemisphere, posing a major challenge to United States foreign policy in the area, President Eisenhower had already taken steps toward determining a new course of United States military assistance. On 24 November 1958, President Eisenhower commissioned the Draper Committee to examine all aspect of the United States Military Assistance Program (MAP). Included in his instructions, President Eisenhower asked the committee to give its - . critical appraisal, after considering all relevant aspects of United States international security programs, of the relative emphas is which should be given to the military and economic programs. 25

The conclusions and recommendations of the Draper Committee were the basis for what the following Kennedy Administration would adopt 
as part of its foreign policy initiative in the early 1960s. Specifically, the Draper Committee concluded that

- . the military forces of many of today's less developed countries can contribute to their countries' economic progress. They can construct such public works as bridges, dams, waterways, and roads; open new agricultural lands; contribute to higher health and sanitation standards; provide technical and vocational training applicable to economic development, and by the training of military personnel and related activities raise the general level of literacy and basic education. With only a small amount of aid the United States could substantially further such contributions. 26

The conclusions of the Oraper Committees were formally integrated into United States foreign policy by the enactment of the Mutual Security Act of 1959. This act provided that

Administrators of the military assistance program shall encourage the use of foreign military forces in underdeveloped countries in the construction of public works and other activities helpful to economic development. 27

By the start of the 1960s the United States had thus shifted to a policy calling for internal defense in the hemisphere, and had established the direction for future assistance to these nations' civic action programs.

The policy of placing emphasis on civic action programs was relatively easy to implement for several reasons. First, bilateral as well as multilateral channels of military cooperation had already been established in the hemisphere. Inter-American cooperation began to develop in hemispheric defense matters in the 1930s. Then during World War II, the United States began to establish bilateral agreements to obtain military bases in the area. ${ }^{28}$ Earlier, the 
Pittman Act passed by Congress on 15 June 1940 had enabled the United States to sell munitions and materiel to any American nation. However, the Latin American governments were not interested in purchasing out-of-date equipment which the United States offered for sale under the act. This was rectified when President Roosevelt declared the American Republics "necessary in the vital defense of the United States" and as such eligible to receive materiel under the Lend-Lease Act of 11 March 1941. ${ }^{29}$ By 1950, this act provided the American nations (except for Panama and Argentina) with military materiel and services valued at $\$ 460$ million. ${ }^{30}$ Additionally, the Inter-American Defense Board (IADB) was created in 1942 and made a permanent part of the inter-American system in 1954. In October 1945, the IADB recommended that its member states adopt standardization of organization, equipment and training of their militaries.

Finally, in 1947, the Inter-American Treaty of Reciprocal Assitance was signed at Rio de Janeiro. This treaty stated the mutual responsibilities and procedures should an armed attack occur on a member state or the security of the hemisphere be in dançer. ${ }^{31}$ As a result, the framework for military cooperation was already well established.

While the United States entered the 1960s determined to implement a "new and revolutionary" program of civic action in Latin America, it was neither "new" nor "revolutionary" for these nations. The concept of civic action was not a foreign or unknown concept to Latin America, and this also facilitated implementation of the policy. 
In Brazil, army engineers had long been involved in public-works constructions; exploration of the interior; establishment of communication systems; and the development of agricultural colonies. Similar tasks were undertaken by the Peruvian military in the 1940s. Also, after 1936, the Cuban military was involved in an educational program to reduce illiteracy, as well as trying to improve rural living conditions. In Argentina and Mexico the military played an important role in economic development by opening up new roads and constructing schools and hospitals. ${ }^{32}$ In addition, the United States, as early as 1951, had supplied Bolivia with bulldozers and other types of road-building equipment as a means to assist road construction by the military in the nation. 33

The Inter-American Defense Board approved the concept of civic action in a resolution passed in December 1960. This resolution recommended

-. . that the governments of the American States take into consideration the advisability of employing organs of their armed forces, preferably in regions considered to be underdeveloped in order to (1) undertake highway and settlement work, and promote the establishment of technical services; (2) broaden the economic bases directed toward raising the standard of living of the peoples; and (3) educate the native populations in their own surroundings and create reserves of specialized labor for specific types of work. 34

This recommendation followed shortly after publication in 1959 of a study conducted by the Chief of Civil Affairs, Department of the Army concerning the lessons learned from the AFAK experience. This study both endorsed the use of civic action programs to assist in nations' development and called for civic action training teams to aid United 
States military personnel abroad. ${ }^{35}$ Civic action mobile training teams (CAMTTs) were first dispatched to Guatemala in November 1960 , and to Ecuador in January 1962. An important aspect of the army study was that it visualized a "low-cost or no-cost program" as far as United States Military Assistance funds were concerned: advice or technical assistance would be the heart of the program. However, it was soon evident after the initial use of CAMTTs that funds of some sort would be necessary if the effort was to be successful. 36

What could be called the "formal" program of civic action came under the Kennedy administration. President Kennedy saw the principal danger to stability in the hemisphere as coming from bands of dedicated and disciplined local Communists and not direct Soviet aggression-a view based in part on Premier Krushchev's January 1961 speech touching on the theme of "wars of liberation" and on rennedy's own impression from a personal meeting with Krushchev in Vienna in June 1961.37 Prior to his meeting with Krushchev, President Kennedy had already stated his position on the concept of civic action in March 1961, before Alliance for Progress representatives from Latin America. "The new generation of military leaders," he said, "have shown an increasing awareness that armies cannot only defend their countries - they can help build them." 38 The formal adoption of the term "civic action" was also made during this period. On 7 June 1961 Secretary of State Rusk, testifying before the House Foreign Affairs Committee, stated:

I think also that a military effort under such circumstances cannot be strictly military in the 
old-fashioned sense of the term but has to be combined with civic action. Civic action of a sort which the military itself must be sensitive to and aware of and help with. 39

This marked the first occasion that the phrase "civic action" was publicly voiced in a context which signified the use of a nation's military to aid in nation-building.

In December 1961, President Kennedy issued a key directive entitled, "National Security Action Memorandum No. 119," which related civic action to the stages of subversion.

1. In countries fighting active campaigns against internal subversion, Civic Action is an indispensable means of strengthening the economic base and establishing a link between the Armed Forces and the populace.

2. In countries threatened by external agression, forces should participate in military Civic Action projects which do not materially impair performance of the primary military mission.

3. In countries where subversion or external attack is less imminent, selected indigenous forces can contribute substantively to economic and social development, and such a contribution can be a major function of these forces. 40

With the issuance of this document, a funding formula to support civic action projects was arrived at between the Departments of Defense and State, which specifically involved allocations through the Agency for International Development (AID). According to the plan, funds for equipment and its maintenance and for training of military units for civic action came from the Military Assistance Program (MAP), while AID provided funds for materials, such as lumber, cement, and other construction items, and consumable items such as gasoline. 41 While this was to be the method of funding, the application of the 
process in a given nation was dependent to an important degree on input from the local United States "country team." The country team was composed of the military attachés and representatives of the United States Agency for International Development, the Central Intelligence Agency, military missions, as well as other United States government agencies in the nation. 42

By the end of 1963, thirteen Latin American nations had activated United States-supported civic action programs. At the same time, the United States had completed the shift in orientation from a hemispheric defense strategy to one which emphasized internal security. This focus was clearly demonstrated by the growth of MAP funds for the support of internal security and civic action programs. Secretary of Defense McNamara, in testifying before the House Foreign Affairs Committee on the fiscal year 1965 defense program, estimated that 52 percent of United States military aid was for internal security, while 15 percent was earmarked for civic action programs. 43 Refer to Table 1 for a breakdown by country of the MAP and AID funds that each Latin American nation was programmed to receive between Fiscal Year 1962 and Fiscal Year 1965 to support civic action programs. Civic action programs which were established in the Latin American nations showed a great diversity as to each nation's needs and abilities to conduct the program. For example, Guatemala, to help reduce the 72 percent illiteracy rate, established a program called the Army Alphabetization Center (AAC). This program was instituted to help teach new army recruits but was soon expanded to 


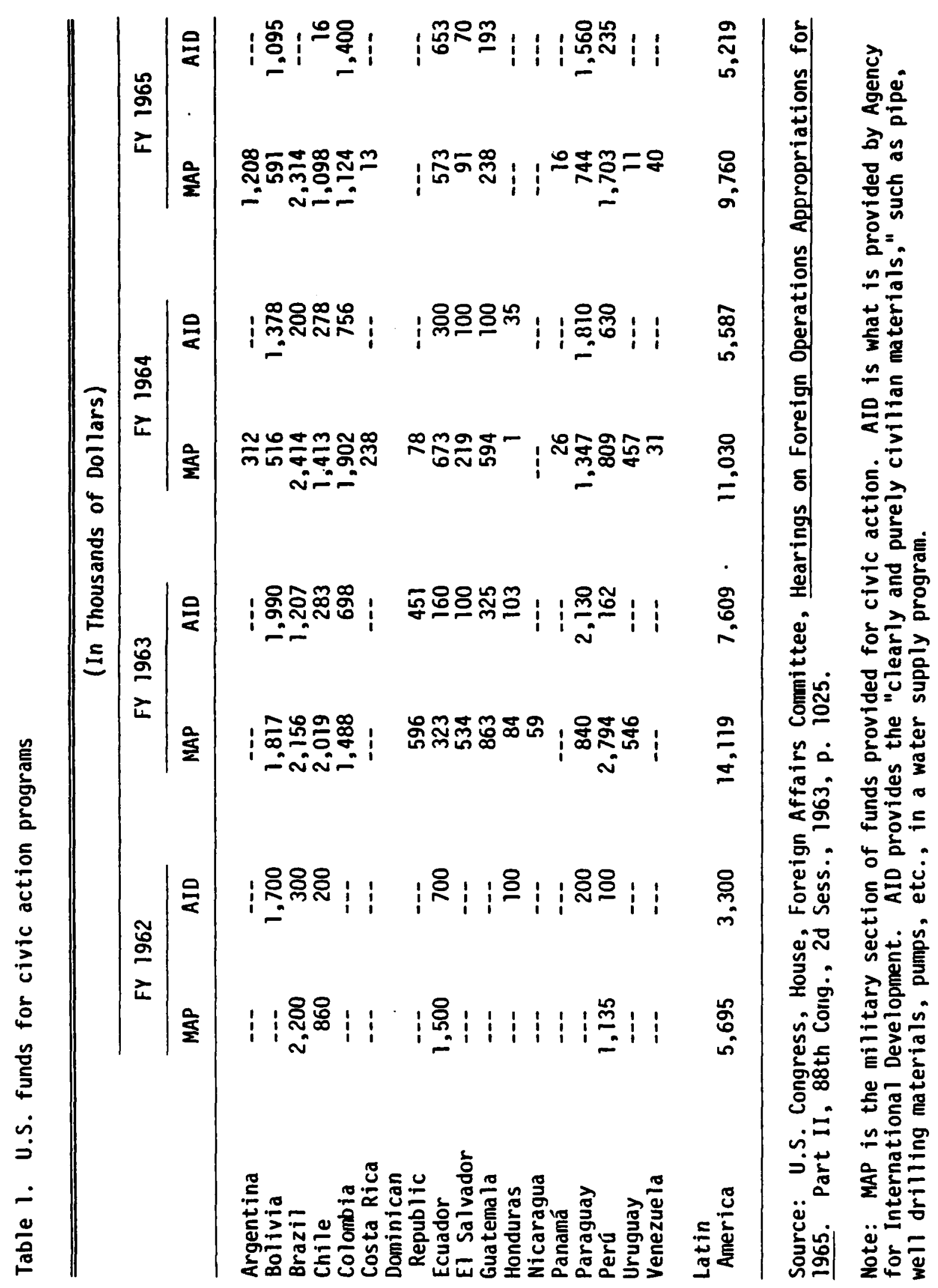


help educate civilians. 44 Ecuador established a three-phase program which emphasized (1) road construction and developing and improving the potable water supply; (2) school construction and water supply distribution; (3) population resettlement and the improvement of agricultural production. 45 Finally, Brazil with AID funds and MAP construction equipment, began a road construction project in May 1963 to assist in establishing cormunications in the northeast area of the nation. 46 Clearly, a variety of civic action programs was established throughout Latin America during this period. And, in 1965, the Foreign Assistance Act of 1961 was in fact amended to make civic action an official objective of the Military Assistance Program as well as to broaden the circumstances under which indigenous civic action programs might be supported. 47

While the concept of civic action has been a much discussed topic for several of the Latin American nations, it has not been so in the case of Colombia. Yet there are several reasons why Colombia warrants closer attention in this context. First of all, the Colombian experience with its level of domestic violence has been an example in which the role of civic action and its impact on reducing violence, as well as furthering national internal development, has been largely overlooked. While there is a general acceptance that the Colombian military was one of the best defense forces in the hemisphere for handiing internal conflict, the method and results of its civic action programs have been largely ignored. ${ }^{48}$ Colombia's internal violence was not only political but involved economic and 
social considerations as well, although it was politics which provided the spark to the violence. The Colombian experience with its civic action programs, on initial examination, appeared to have contributed to national development and aided in the government's program to end la violencia. Additionally, the discussion of the civic action programs conducted in Colombia may highlight projects which developing nations of today may use to assist in their own development. However, before discussing Colombia's civic action programs, the phenomenon which became known as la violencia must be examined, in order to uniderstand the circumstances these programs had to succeed against. 
Notes

IU.S. Joint Chiefs of Staff, Dictionary of United States Military Terms of Joint Usage, JCS Pub. 1 (Washington, D.C.: U.S. Government Printing Office, August [969), p. 112.

${ }^{2}$ Edward Bernhard Glick, "The Non-Military Use of the Latin American Military," in Latin America: Politics, Economics, and Hemispheric Security, ed. Norman A. Bailey (New York: Frederick A. Praeger, Inc., 1965), pp. 180-181.

3Lyle N. McAlister, "The Military," in Continuity and Change in Latin America, ed. John J. Johnson (Stanford, California: Stanford University Press, 1964), p. 143.

4Neh. 4: 17-18 (LB). [LB=The Living Bible.]

${ }^{5}$ Edward Bernhard Glick, Peaceful Conflict: The Non-Military Use of the Military (Harrisburg, Pennsylvania: Stackpole Books, 1967), p. 33 .

6 Harry F. Walterhouse, A Time to Build: Military Civic Action-Medium for Economic Development and Social Reform (Columbia, South Carolina: University of Scuth Carolina Press, 1964), p. 57.

7Williard F. Barber and C. Neale Ronning, Internal Security and Military Power: Counterinsurgency and Civic Action in Latin America (Columbus, Chia: Ohio State University Press, 1966), p. 54.

8 Wal terhouse, Military Civic Action, p. 56.

${ }^{9}$ Gi ick, Peaceful Conflict, p. 46.

${ }^{10}$ Wal terhouse, Military Civic Action, p. 58.

11 Glick, Peaceful Conflict, p. 47.

12 Wal terhouse, Military Civic Action, p. 70.

13 Ibid., p. 72.

14 Barber and Ronning, Civic Action in Latin America, p. 57.

${ }^{15}$ Ibid., pp. 58-61.

16U.S. Department of Defense, "Civic Action: The Military Role in Nation Building," For Commanders 3 (15 January 1964): 1 .

17 Ibid., pp. 1-2. 
18 Walterhouse, Military Civic Action, pp. 87-88.

19 Anthony J. Auletta, "Ten-Nation Progress Report," Army 13 (July 1963): 53.

20 Ibid.

${ }^{21}$ U.S. President, Committee to Study the United States Military Assistance Programs, Supplement to the Composite Report, vol. 2 (Washington, D.C:: U.S. Government Printing Office, June 1959), p. 132 .

22 Ibid., Pp. 132-133.

23 James A. Sandos, "U.S. Military Policy toward Latin America," World Affairs 135 (Spring 1973): 294.

24 Ibid.

${ }^{25}$ U.S. President, Committee to Study the United States Military Assistance Programs, Conclusions Concerning the Mutual Security Program (Washington, D.C.: U.S. Government Printing Office, June 1959), p. 22.

${ }^{26}$ Ibid. , p. 42.

27 Ibid.

${ }^{28}$ Barber and Ronning, Civic Action in Latin America, p. 63.

${ }^{29}$ Raymond Estep, United States Military Aid to Latin America (Maxwell Air Force Base, Alabama: Air University Documentary Research Center, 1966), pp. 15-17.

30 Ibid., p. 19.

31 Barber and Ronning, Civic Action in Latin America, pp. 63-64.

${ }^{32}$ John J. Johnson, The Military and Society in Latin America

(Stanford, California: Stanford University Press, 1964), p. 139.

${ }^{33}$ Estep, Military Aid, p. 63.

34 Ibid., pp. 65-66.

${ }^{35}$ Martin F. Massoglia, Philip S. McMullan, and Clarence N. Dillard, Military Civic Action-Evaluation of Military Techniques (Research Triangle Park, North Carolina: U.S. Army, July 1971), p. II-2. 
${ }^{36}$ Department of Defense, "Civic Action," pp. 2-3.

37 Barber and Ronning, Civic Action in Latin America, pp. 2-3.

38 Harry F. Walterhouse, "Good Neighbors in Uniform," Military Review 45 (February 1965): 16.

${ }^{39}$ Estep, Military Aid, p. 66.

${ }^{40}$ Glick, Peaceful Conflict, p. 71.

41 Department of Defense, "Civic Action," p. 3.

42 Barber and Ronning, Civic Action in Latin America, pp. 98-99.

43 Harold A. Hovey, United States Military Assistance: A Study of Policies and Practices (New York: Frederick A. Praeger, Publishers, (965), p. 60.

44 Auletta, "Ten-Nation," pp. 53-54.

${ }^{45}$ Robert L. Burke, "Military Civic Action," Military Review 44 (October 1964): 67.

46 Ibid., pp. 64-65.

47Massoglia, McMullan, and Dillard, Military Civic Action, p. II-2.

${ }^{48}$ Howard I. Blustein et al., Area Handbook for Colombia (Washington, D.C.: U.S. Government Printing Office, 1977), P. 426. 
BACKGROUND AND DISCUSSION

OF

LA VIOLENCIA

By the mid-twentieth century, few nations in the world had suffered the levels of internal violence which Colombia endured from 1946 to 1965. Violence raged within Colombia for approximately twenty years and left thousands dead. The estimates on the number killed vary according to what. source is used. The study completed by Germán Guzmán, Orlando Fals Borda, and Eduardo Umaña Luna, La violencia en Colombia: Estudio de un proceso social, places the number of dead at 200,000 by 1962. 1 On the other hand, Russel1 W. Ramsey in his study, "The Modern Violence in Colombia, 1946-1965," estimates the total to be $159,000 .^{2}$ No matter what source is used, it is quite evident that the death toll was sizeable. As E. J. Hobsbawm has observed, "It represents what is probably the greatest armed mobilization of peasants (as guerrillas, brigands or self-defence groups) in the recent history of the western hemisphere, with the possible exception of some periods during the Mexican Revolution." ${ }^{3}$ Additionally, the economic cost to the nation was significant. As an example, by 1955, the Department of Tolima is estimated to have had a loss of approximately 970 million pesos worth of property, which almost equaled the Colombian national budget for that year. 4 clearly, la violencia, as it was known, was an enduring and prominent segment of modern Colombian history. 
Internal violence was not a new experience to Colombia as the nation had suffered other periods of internal conflict. Since independence, Colombia had experienced civil conflict during the following time periods: 1830-1831, 1839-1841, 1851, 1854, 1860-1861, 1876, 1885, 1895, and 1899-1902. ${ }^{5}$ Colombia had further experienced a pre-independence civil conflict with the revolt of the Comuneros in March-June 1781, who rebelled against the Spanish authorities over taxation policies. Yet, while civil conflict was not new, the duration of la violencia was significantly longer than that of earlier conflicts.

The violence which had occurred throughout the nineteenth century centered primarily on political competition between the Liberal and Conservative parties. This series of civil conflicts culminated in the War of a Thousand days, which lasted from July 1899 until June 1902. This was the final attempt by an "out" party, the Liberals, to gain control of the government, over the party that was in power, the Conservatives. The fighting included rural guerrilla warfare and few set battles. This would resemble the nature of conflict of la violencia. The ferocity of the conflict, which left 100,000 dead, would also be repeated later during la violencia. 6 With the defeat of the Liberals, the Conservatives remained in power until 1930.

As of the beginning of the twentieth century, internal violence based on political affiliations was thus an established tradition in the nation. All active political participants belonged to one party 
or the other, and membership in a particular party was practically a right of birth. ${ }^{7}$ However, while the political balance remained unchanged during the first part of the twentieth century, the economy underwent significant change. After the War of a Thousand Days, the nation experienced an expansion of the coffee industry as well as the growth of manufacturing and petroleum industries in the first three decades in the century. Accompanying the economic expansion was the rapid growth of population. Between 1912 and 1929, the population increased from about five million to slightly under eight million. This rapid growth placed increased pressure on the available land resources and helped to stimulate migration to the urban centers. 8

The economic growth which characterized Colombia in the 1920 s came to be known as the "dance of the millions." 9 The payment of $\$ 25$ million from the United States in 1921-1922, under the terms of the Thomson-Urrutia Treaty for the loss of Panama, encouraged the government to seek more rapid development of transportation and other infrastructures. During the administration of President Pedro $\mathrm{Nel}$ Ospina (1922-1926) foreign borrowing was likewise greatly expanded. 10 This heavy borrowing, begun during the Ospina administration and especially from U.S. bankers, increased the national foreign debt, as in 192767 million pesos were borrowed, whereas between 1920 and 1926 only 51 million pesos had been borrowed. 11

While the nation was experiencing economic expansion in the years prior to the world depression, there was still civil violence, although it was not as widespread or intense as that which had 
characterized previous conflicts. The most conspicuous instances were the result of agrarian and labor unrest. A factor contributing to agrarian unrest was the movement of squatters onto public and sometimes private lands, especially when ownership titles were unclear. $^{12}$ Land tenure conflicts had been less frequent and settled more easily prior to the growth of the coffee industry as agricultural production had been less lucrative and land was more readily available. Accompanying the growth of the coffee industry in the early twentieth century was a regional shift in the production areas. The primary areas of cultivation moved from the western and northern regions of Cundinamarca and Norte de Santander to Antioquia, Caldas, Tolima, and Valle-which were to be major centers of la violencia. ${ }^{13}$ Even though agrarian unrest was growing in intensity, it was in the labor arena that the most serious outbreaks of violence occurred. Workers struck the American-owned Tropical 0il Company on several occasions in the 1920s, with the government using force in January 1927 to end one strike. ${ }^{14}$ However, the worst instance of labor violence occurred in the banana industry. A major strike broke out on 11 November 1928, in the region of Santa Marta against the American-owned United Fruit Company. This strike was motivated by the poor working conditions on the plantations and the lack of response from the company to the workers' grievances. 15 The government responded by declaring martial law on 5 December 1928 and employed the military to break the strike. Over one thousand people were killed and two thousand wounded during the next two months as the 
military and police battled the strikers. ${ }^{16}$ This conflict and the following world depression together set the stage for a shift from Conservative to Liberal leadership in the national government. 17 The elections of 1930 saw the Liberals gain the presidency with Enrique 0laya Herrera. Olaya's victory came as the result of the Conservative party being split between two candidates. In fact, 0laya garnered only 44.9 percent of the total vote, while the rival Conservative candidates split the remainder. 18 Thus, once again, the outcome of an election was determined by a split within one of the parties as had been the case on several occasions in the nineteenth century.

While the transfer of power in 1930 at national level was reasonably peaceful, there were outbreaks of violence in some parts of the country. These were largely the result of Liberals taking revenge against Conservatives. Liberals still remembered the defat they suffered at the hands of the Conservatives in the War of a Thousand Days. In addition, the Liberals had often been harassed by the Conservatives and the police, especially during election periods. 19 Therefore, the Liberals in the countryside seized the opportunity, as the party in power, to settle old debts with the Conservative party.

Violence broke out initially in the following departments: Boyaca, Santander, and Norte de Santander. The violence then spread to include Cundinamarca, Antioquia, and isolated areas in western Caldas as well as a few outbursts in Tolima. In addition to 
political antagonisms, family feuds. of what one author has termed the "Hatfield-McCoy" variety came into play over longstanding disagreements and led to a self-generating cycle of violence. ${ }^{20}$ The combined death toll from all the types of violence has been estimated at ten thousand. 21

The violence which had erupted was short in duration. In September 1932, Peruvians occupied the Leticia area which is the narrow segment of Colombia stretching to the Amazon River. With the outbreak of the conflict with Peru, there was a nationalistic outpouring in Colombia which overshadowed the political rivalries. 22 This conflict, in effect, acted as a unifying force to help and the violence before it got out of hand. Unfortunately, no similar occurrence would appear after 1946 to help stop the violence which again erupted.

The Liberals maintained control for the next sixteen years, before being defeated due to a division within the party which was similar to what had happened to the Conservatives in 1930. Meanwhile, the Liberais set to work to bring about social and economic reforms. The major reforms were carried out by President Alfonso Lopez Pumarejo (1934-1938). President Lopez was initially stymied by Congress, as it was controlled by moderate Liberals and Conservatives. However, the 1935 Congressional elections brought the reformist Liberals control of Congress and enabled Lopez to enact this program. ${ }^{23}$

The reforms which Lopez sponsored probably reflected several foreign influences. These included the reforms formulated by the 
Mexican Constitution of 1917, which favored social welfare, land redistribution, and labor organization; the program of the Peruvian Alianza Popular Revolucionaria Americana (APRA); and also the social-reform objectives which Franklin $D$. Roosevelt incorporated into his New Deal. 24 The culmination of Lopez's program, which he called "La Revolucion en Marcha," was his move to amend the constitution in 1936. The amendments adopted, together with certain laws which were passed in accord with their provisions, became known as the "Codification of 1936."

As part of the Lopez reforms, the literacy and property qualifications for suffrage were eliminated for presidential and congressional elections. The power of the Church was reduced; no longer would it organize and direct public education. Also, the new amendments specifically removed mention of Roman Catholicism as the religion of the state. 25 Labor also benefited in that under Article 40, Title III, "labor is a social obligation, and it shall enjoy the special protection of the state." 26 With this legal sanction, Colombia's once persecuted unions joined in a major organization, the Confederacion de Trabajadores de Colombia (CTC), which by the end of 1936 included some nine hundred unions with 100,000 workers. 27 Land reform was likewise instituted by the enactment of Law No. 200 of 1936, which gave peasants "squatters' rights" on public as well as private lands if some improvements were made to the land. ${ }^{28}$ However, landowners often circumvented the law by such tactics as destroying houses and any other improvements made by 
their workers, as a means to forestall possible claims against their property. 29 Progressive taxes on income and inheritances were also established, and improved tax collecting procedures implemented. Finally, private property was declared to be no longer an absolute right, but rather now it included a social obligation. 30

The reforms of President L6pez were not readily accepted by all sectors of society. Many wealthy Colombians resented the inroads the government was making or attempting to make against their economic position. Indeed, President Lopez was opposed by the more conservative elements of his own Liberal party as well as the Conservatives who feared the possible consequences of "Lopismo." 31 The leader of the more moderate Liberals, Eduardo Santos, was opposed by Lopez as the party's nominee in the 1930 election, which in turn widened the growing rift in the Liberal party. 32 Santos was easily elected, however, as the Conservatives boycotted the elections, and he began to slow the pace of La Revolucion en Marcha. Under Santos' administration. Conservatives were brought into the government, and the importance of labor and reformist-oriented Liberals diminished. ${ }^{33}$

Alfonso Lopez, by his actions during the Santos administration, helped plant the seed of further party dissension. Lopez founded the newspaper El Liberal, which he used to attack the President and the moderates, just as they had previously criticized his reforms. This antagonism between rival wings of the Liberal party would set the stage for the eventual return to power of the Conservative party. 34 First, however, Alfonso Lopez decided to run for a second term of 
office in 1942 with the division within the Liberal party greater than it had been four years earlier. Lopez won, but only after a bitter political fight against the candidate of the more moderate Liberals, who had the reluctant support of the Conservatives. 35 The Conservatives did not put forward a candidate of their own lest they push the Liberal factions back together.

The leader of the Conservatives, Laureano Gomez bitterly opposed the return to power of L6pez. Gormez, on the floor of Congress, vowed he would lead a revolt against Lopez, which raised fears of a repetition in Colombia of General Franco's uprising against the Republic in Spain. ${ }^{36}$ Although an armed revolt did not develop, Gomez did attack President Lopez through a campaign of press attacks that reached a high pint over the "Mamatoco" affair. Mamatoco was a prize fighter supposediy murdered by the Liberals because he knew too much about official scandals. Gómez responded to this political crisis with inflammatory editorials in his newspaper El siglo, stating that the individual had in fact been murdered to be kept quiet. Gomez was jailed for slander, as the political situation grew steadily more tense. 37

The final act for President Lopez came on 10 July 1944. Lopez and some of this cabinet members were apprehended while observing army maneuvers at Pasto. The leader of the coup, army Colonel Diogenes Gil Mujica, called on the rest of the army to revolt. However, the remainder of the military remained loyal, and the coup was easily defeated. While there appeared to be some prior planning to the coup, 
the ease with which it was defeated suggests that support in the military was not widespread. ${ }^{38}$ Even so, this event highlighted the declining support of President López and hastened the end of his administration. In August 1945, L6pez resigned, feeling exhausted as a result of continued personal attacks in the press, opposition from and division within his own party and conflicts with Congress. After he stepped down, Alberto Lleras Camargo assumed the interim presidency and served out the remainder of Lopez's term.

The presidential election of 1946 was again marked by division within the governing party. The division reflected sharp ideological differences between two competing candidates: Gabriel Turbay and Jorge Eliécer Gaitán. Although Turbay had been a supporter of the Colombian Communist Party in the 1920s and had supported Lopez and his reforms in his first administration, by the 1940s he was more moderate in his outlook. Gaitán had also supported Lopez's first administration, but had continued, if not hardened his reformist liberal position. 39 Indeed, in 1933 Gaitán had organized the Unión Nacional Izquierdista Revolucionaria (UNIR) as a means to agitate for social reforms; however, he returned to the Liberal party when the UNIR failed to gain support.

Unlike 1942, the Conservatives this time chose to contest the election and united behind a single candidate, Mariano Ospina Pérez, with Laurenao Gómez stepping aside to prevent the Liberals from closing ranks against him. The election results on 5 May 1946 mirrored the split in the Liberal party: Turbay received 437,089 
votes; Gaitan followed with 363,489 ; but the Conservative Ospina Perez received $565,894.40$ Therefore, the Conservatives were back in power after garnering only 42 percent of the total vote. The political pendulum had again been moved due to a split in the ruling political party, and violence soon accompanied this shift.

Although violence began to erupt by October 1946, it was not for a lack of leadership on the part of Ospina Pérez. Realizing the weakness of his position, Ospina Perez sought to mollify, if not win over, the Liberal party. ${ }^{41}$ Ospina Perez brought six Liberals into his cabinet, balanced with an equal number of Conservatives. Ospina Pérez stated:

- . Under my administration there will be no political reprisals on the part of the authorities against persons or their property; no one will be barred from public office for party reasons; I faithfully guarantee to all the exercise of their natural and civil rights, and I shall make it my care to see that public liberties are respected. Neither the head of the state nor his associates or agents will take any step that even remotely smacks of political reprisals against anyone. 42

Even with his apparent middle and unifying stance, Ospina Perez could not prevent the outbreak of violence, and this time there would be no nationalistic unifying factor to bring it under control as had been the case after 1930.

Violence first broke out in a spontaneous manner in the Department of Nariño in the far south. The pattern of violence which emerged was based on political revenge, as newly appointed Conservatives taunted recently removed Liberals or vice versa. Violence would be employed to retaliate; the Liberals using mob 
action while the Conservatives relied on the village police department. 43 According to German Arciniegas, "Little by little [Ospina Perez] began modifying the organization of the police force, which in the provinces was transformed into shock troops at the service of the Conservatives." 44 In those instances where the police were likely to be defeated, the Conservative officials tried to call in the military to prevent defeat.

While the army had been reasonably successful in containing and moderating violence during the election campaign, it failed to play as successful a role with this new outbreak of violence. The violence was not centralized or localized, but rather spread out in hundreds of small cormunities where the Conservatives now assumed power. Due to this dispersion of violence, the army was not of a sufficient size to contain it, as it numbered only 10,820 men and lacked adequate transportation to move to troubled locations. 45 Moreover, the military was obedient to the elected civilian government, and as such could be used by the elected officials to assist in repressing Liberal opponents or simply ordered from areas where Conservatives were going to engage Liberals. 46

The government responded to the outbreaks of violence often by replacing civilian alcaldes with military officers. Also conciliatory messages were sent to political leaders in regions of political violence. $^{47}$ However, as 1946 ended, both parties began an electorate campaign for the March congressional elections and become fixed on that event and not conciliation. The election of March 1947 resulted 
in the Liberals receiving 805,874 votes, while the Conservatives received but 653,936 . Also within the Liberal party the relative strength of Gaitán's supporters in Congress grew. The idea of a national union government, which had been first developed under Lleras Camargo and partially sustained by Ospina Perez, was on borrowed time as Gaitán denounced any form of coalition. ${ }^{48}$

All that remained to elevate the level of violence was a spark to ignite the situation. The spark came on 9 April 1948, when Jorge Eliécer Gaitán was assassinated by a demented individual in Bogotá. Violence and rioting erupted as Gaitán's followers sought revenge for their murdered leader. This violence broke out during the IX Inter-American Conference, lasted for two days, and came to be known as the bogotazo. It was without direction or coherent objectives, rather the rioting was the work of a leaderless mob. ${ }^{49}$ Although an attempt was made by the rioters to seize Laureano Gomez, he escaped into exile to Spain. The death toll numbered two thousand, and a large section of downtown Bogota was destroyed before the army gained control of the situation. 50 The intervention of the army was necessary, as the police defected to the rioters and the military was left as the only organization that could restore order. 51

President Ospina Pérez was able to restore the national union coalition by again dividing positions between the two parties. This coalition held until 21 May 1949, when the Liberals resigned from government as a protest against the administration's failure to preserve order and guarantee from elections. 52 Indeed, violence was 
both growing in intensity and becoming more widespread. Tensions grew to such an extent that local Liberal leaders supported or formed guerrilla bands (cuadrillas), with Conservative forces countering with vigilante groups to attack the Liberals. 53

In the face of this growing violence congressional elections were held on 5 June 1949. The Liberals received 920,718 votes as opposed to the Conservatives' 788,662 , which enabled the Liberals to retain their majority in both houses of Congress. 54 The Conservatives believed and stated that there was vote fraud, while the Liberals declared a great victory. The Liberals' control in Congress developed into an institutional conflict which pitted the legislature against the national executive. This focused on the Liberals' proposal to move up the date for the next presidential election from June 1950 to November 1949. Although Ospina Perez vetoed the law which had been passed, the Supreme Court rejected this veto, and the presidential election was scheduled for later in the year. 55

Violence then moved to the floor of Congress, where Gonzalo Jimenez, a Liberal Congressman, was shot and killed on 7 September 1949, by a Conservative Congressman. The Liberal-controlled Congress attempted to impeach President Ospina Perez, but the president reacted by calling the action of Congress subversive. The president, on 9 November 1949, issued a series of decrees which closed Congress, established press censorship, prohibited public gatherings, granted full powers to department governors, and declared a state of siege. Under these circumstances, the Liberal party chose to abstain from 
the presidential election rather than present a target for Conservative attacks. 56 Therefore, the Conservative candidate ran unopposed, and on 27 November 1949 Laureano Gómez was elected.

With the election of Gomez the level of violence increased along with a further geographic spread of the areas involved. Only the Atlantic and Pacific coastal zones were not affected by la violencia during this period. Guerrilla leaders capitalized on the guerrilla legacy in the 1 lanos orientales and moved their forces from central to eastern Boyaca as well as Meta. These forces developed from the Liberal guerrilla forces which had started to be formed at the end of 1948. By the end of 1952, there were approximately twenty thousand guerrillas operating in the eastern plains area. 57

Other armed groups were organized during this initial period of la violencia with a decidedly different ideological outlook from the Liberal cuadrillas. In southern Tolima, Communists also formed cuadrillas that fought against the Conservative as well as Liberal forces. Additionally, in October 1949, the Communist party announced the policy of "self-defense of the masses," and began to organize and indoctrinate the peasants as a means to establish enclaves, such as the one that emerged at viota. 58 Conversely, the government began to organize counterguerrillas (guerrillas de paz) in early 1950 and employed these forces in the llanos region to counter the growing Liberal forces. Also during this period the government formed and trained the police Battalion "Vargas" specifically to fight the Liberal cuadrillas. This battalion took over the pacification duties 
of the army in the llanos region and began a reign of terror to destroy the Liberal forces. ${ }^{59}$ However, the government under Gomez also pursued other policies as a means to end the violence.

Gomez attempted - in a move that ultimately proved unsuccessfulto reform the constitution in such a way as to combine traditional Conservative republicanism and elements of European corporatism. ${ }^{60}$ Gomez also moved to fragment the labor movement, and he annulled a number of pro-labor laws enacted during Alfonso Lbpez's first administration. As an example, Gômez ended the law which forbade the establishment of parallel unions in industry and thus permitted the development of unions under management control. Civil liberties were similarly reduced, as a means to halt the growing political violence. Indeed, on 20 October 1950, the Minister of War, Roberto Urdaneta Arbeláez, issued a "Warning to All Citizens" decree that defined as bandits all those who opposed the military forces. The decree covered everyone sixteen years and older who hid from the military, and it granted the military the power of summary execution wherever officers considered it appropriate. ${ }^{61}$ Yet in spite of such measures, as well as continuing press censorship, violence increased. ${ }^{62}$

During the early period of his administration Gomez enjoyed support from a variety of sources. Within the Conservative party, Gómez had some middle class backing, but it was the more traditional segments of society which provided him the greatest support. These groups included the campesinos of the Andean interior, the clergy, and the landed elite. The objective of Gomez was to return political 
institutions to a form which conserved traditional values while at the same time promoting economic development where possible. 63

The economy was prosperous during the Gómez years, largely as the result of expanding markets and favorable prices for coffee, which was the nation's principal cash export. Increased levels of foreign investments were also encouraged through decrees which both permitted the free importation of capital equipment or currency and allowed for re-exportation of profits without time restrictions. 64 However, this prosperity was centered mainly on the Colombian elite and industrial workers, whose wages rose, while other segments of the lower classes were hurt economically both by rising prices and by side effects of la violencia. 65

A variation on the political violence which had been occurring also took place during Gómez's administration. In 1951, violence widened to include religious persecution of Protestants. Protestant missionaries had understandably found tolerant attitudes toward their work under the Liberals' control from 1930 to 1946 . The shift to Conservatives brought a market change in the government's attitude. Under the Conservatives, Protestant missionaries were limited in various ways. They were forbidden to use mass media or openly to proselytize. With the increased levels of violence, Conservative forces often turned against Protestants, because the latter were overwhelmingly aligned with the Liberals. 66

The position of Gómez ultimately began to weaken for several reasons. First, Gomez faced dwindling support within his own party. Ospina Pérez planned on running for president in 1954, but this 
conflicted with Gómez's plans for implementing a semi-corporatist type of government, which Ospina Pérez opposed. Also, some members of the Conservative party, led by Gilberto Alzate Avendaño, were even more right-wing in ideology than Gómez. Alzate Avendaño challenged Gomez for party and national leadership. Then, too, the elite sector of Colombian society, while initially supportive, became convinced that someone as inflexible as Gomez could not end the civil conflict without seriously damaging the economy. Finally, the military questioned the efficacy of Gómez's repressive policies and began to tire of its role as an instrument to repress fellow countrymen. ${ }^{67}$ It was in this setting that the military, under General Gustavo Rojas Pinilla, seized control of the national government on 13 June 1953 and ended the dictatorship of Gómez.

What began as an outbreak of violence so similar to past outbreaks in the nation had grown in size and intensity from 1946 to 1953. According to Ramsey, the number of guerrilla forces reached 45,000 , while Guzman places the number at 30,000 at the end of this phase. No matter what figure is used, it was evident that la violencia involved a large number of rural guerrillas. Also, by 1953, there were thirteen major guerrilla commands operating in the nation; but there was virtually no coordination between them, except to some extent in the llanos. 68

The assumption of power by Rojas Pinilla marked the end of the first wave of la violencia. During this initial period (1946-1953) violence had spread from the Santanders and western coffee-producing 
areas through most of the nation to include the 1 lanos region. Major centers for the violence were the western departments of Tolima, Antioquia, Valle, and Caldas, as well as the eastern llanos. Specific casualties by region are listed in Table 2. Except for the llanos, areas which incurred the greatest number of deaths not only were devoted primarily to coffee production, but were frontier areas of colonization and numerous small holdings of tenants and squatters. 69 Conversely, areas with established coffee plantations were less affected by the violence. This correlation between the areas with the highest violence levels and state of rural development was observed by anthropologist Luis Duque Gómez, who wrote in 1954:

It is curious to note that besides favorable topographical conditions, the zones affected by political violence coincide exactly with the fronts of modern colonizations which in recent years have been pushing ahead in the regions of the Carare, the northeast of the Department of Antioquia, the north of Tolima, the border zone between the latter department and the Valle del Carica, some areas along the banks of the Magdalena and in the eastern plains. 70

The assumption of power by the military introduced a new period in la violencia that began hopefully but soon deteriorated to resemble the earlier phase. The military took power amid a wave of popular support from both Liberals and Conservatives, although Rojas did from the outset allow his administration to become c'osely identified with the Conservatives. 71 However, Rojas took immediate measures designed to end the civil conflict. First, Rojas established an amnesty program or la entrega, whereby guerrillas could surrender in exchange for pardon for all crimes, protection from 
Table 2. La violencia death toll (August 1946-June 1953)

\begin{tabular}{|c|c|c|}
\hline & $\begin{array}{l}\text { Department or Region } \\
\text { (Pre-1965 Names) }\end{array}$ & Deaths \\
\hline $\begin{array}{l}1 . \\
2 . \\
3 . \\
4 . \\
5 . \\
6 . \\
7 . \\
8 . \\
9 . \\
10 . \\
11 . \\
12 . \\
13 . \\
14 .\end{array}$ & $\begin{array}{l}\text { Antioquia } \\
\text { Bolfvar (including Cordoba) } \\
\text { Boyaca (western) } \\
\text { Caldas } \\
\text { Caqueta } \\
\text { Cauca } \\
\text { Cundinamarca } \\
\text { Choc6 } \\
\text { Huila } \\
\text { Llanos Orientales } \\
\text { Santander } \\
\text { Norte de Santander } \\
\text { Tolima } \\
\text { Valle } \\
\text { TOTAL }\end{array}$ & $\begin{array}{r}11,100 \\
400 \\
2,650 \\
5,150 \\
200 \\
1,500 \\
3,150 \\
500 \\
2,100 \\
10,500 \\
2,600 \\
2,350 \\
14,500 \\
5,850 \\
62,550\end{array}$ \\
\hline
\end{tabular}

Source: Russell W. Ramsey, "The Modern Violence in Colombia, 1946-1965" (P'n.D. dissertation, University of Florida, Gainesvilie, 1970), p. 449 .

retribution, and economic assistance. Additionally, the national police were removed from the control of the Minister of the Interior and established as the fourth branch of the armed forces as a means to depoliticize it. Political prisoners in custody were released, and for a time there was a relaxation of governmental press controls. 73 The government's amnesty program produced immediate and dramatic results. In August and September, a total of 3,540 guerrillas in the llanos surrendered while throughout the nation a total of 6,500 guerrillas accepted the amnesty by 5 September 1953.74 By the end of the year, an estimated twenty thousand guerrillas had surrendered or had simply gone home. However, some guerrillas, although few in 
number, did not accept the amnesty program and preferred to continue their struggle. As an example, Communist cuadrillas continued to operate in southern Tolima, as did rural guerrillas in southeastern Cundinamarca and eastern Tolima. 75

While the amnesty program did help in reducing the levels of violence, it was not the only program the government relied upon to try to end the violence. Rojas increasingly relied on military force as wel1. The newly returned troops from the Korean War were used in mid-1954 to sweep through Tolima as a means to destroy the guerrilla forces located in the department. The guerrillas were not decisively defeated, while many farms were destroyed and families forced to migrate. 76 This was one of the errors of Rojas in attempting to arrive at a solution to the violence, for it had the effect of stiffening the resolve of the existing cuadrillas and making new refugees from the areas the military swept.

As still another approach to the problem, Rojas established a number of relief and social welfare programs. On 2 July 1953, the Office of Rehabilitation and Assistance (Oficina de Rehabilitacion y Socorro) was established to assist displaced persons and refugees. As a part of this program, the Agricultural Credit Bank (Caja de Credito Agrario) was to make loans of up to one thousand pesos for the reconstruction of farm homes and buildings. These measures were soon followed by the formation of the Institute of Colonization and Immigration (Instituto de Colonización e Inmigración) in August 1953. This agency was formed to help open and develop lands owned by the 
government and provide technical assistance to the settlers. Then, on 1 September 1953, Rojas established the Coffee Grower's Bank (Banco Cafetero $y$ de Exportaciones), with capital amounting to 50 million pesos, to help expand cultivation and the processing and export of coffee. Lastly, in December, the Agrarian Planning Commission was formed to study agrarian conditions in the nation and recommend changes to increase production as well as improve the living conditions of the campesino. 77

Rojas also organized, in September 1954, the National Secretariat of Social Assistance (Secretariado Nacional De Asistencia Social-SENDAS) as a social welfare organization to assist refugees, workers, and farmers. This organization was headed by Rojas' daughter, Marfa Eugenia Rojas de Moreno, and brought all other social welfare organizations under its control. The organization, SENDAS, was somewhat similar to the Fundación Eva Perón which Perón had established in Argentina. However, SENDAS did not develop the popular support or success which the Argentine agency did. 78

Rojas attempted to establish a broad base of popular support, through the Movimiento de Accion Nacional (MAN) which he permitted to be established as a coalition of Liberals and Conservatives in December 1954. This organization was envisioned as acting as a third force or political movement "above the parties." However, MAN was not successful, as the traditional attachments to the respective political parties could not be circumvented. Also, MAN was opposed by the Church and some elements within the military. 79 
Rojas then provoked the crisis that led to his fall when in 1957 he attempted to force the National Constituent Congress (ANAC) to confirm him as president for a second term that would run from 1958 to 1962. This move to "continuismo" brought strong opposition from the traditional political leaders, capital, the press, high clergy, and ultimately the military. ${ }^{80}$ Because Rojas was without a strong mass political party for support and could not rely on any traditional group for assistance, he was forced to accede to the demands of the military. Therefore, on 17 May 1957, a caretaker military junta assumed control of the government. The removal of Rojas would usher in still another new phase of la violencia, which during his regime had claimed some 26,000 victims. 81

Although violence was still present in the countryside, the areas involved had been reduced due to measures implemented by Rojas. The five departments still seriously affected by la violencia were Caldas, Valle, Cauca, Tolima, and Huila. ${ }^{82}$ Also during the rule of Rojas there was a relative increase to the amount of violence that was not so much politically inspired as a form of socioeconomic banditry. This shift reflected the institutionalization of the violence, which had led to the growth of violentos, "children of the violence," who knew only killing and banditry as a way of life. 83 The Communist-inspired, so-called "independent republics" expanded during this period as well, with those of Marquetalia (southern Tolima) and Sumapaz (southern Cundinamarca) being the most notable. 84 The Communist-led forces made up 10 to 15 percent of the guerrillas 
involved in the violence, but on the whole fought in a self-defense strategy to protect enclaves. They were not aggressive leftist revolutionaries, as they had not the strength. 85

The end of the Rojas regime and the emergence of the National Front government marked a new and final direction for la violencia. Political revenge violence, involving followers of the traditional parties, while still occurring, became relatively unimportant thanks to the introduction of a formalized bipartisan coalition government. Liberal leader Alberto Lleras Camargo and Conservative Laureano Gómez agreed to such a coalition with the signing of the Pact of Sitges on 20 July 1957, under whose terms political cooperation was to continue for tweive years, with each party having parity with the other in Congress as well as public administration. The population was to vote on this agreement in a national plebiscite. ${ }^{86}$ The plebiscite was held on 1 December 1957, and the constitutional reform establishing the National Front system passed overwhelmingly. The reform likewise entailed other significant changes: women received equal political rights with men; Roman Catholicism was again declared the religion of the state; Supreme Court members were to be appointed for life; and the rule of the military junta was legalized until August 1958. 87 However, political conflict was not immediately abated.

One problem arose over the selection of the first candidate for the presidency. Gómez opposed the initially agreed upon Conservative candidate, Guillermo León Valencia, because he was identified as a 
supporter of Ospina Pérez as well as having supported Rojas early in his regime. Therefore, once again it was intra-party factionalism and not inter-party confrontation which threatened to disrupt the political situations. The crisis was alleviated when Gômez recommended that a Liberal and not a Conservative assume the presidency for the first term under the National Front, with a Conservative to have the second term. The Liberais counterproposed to extend the period of the National Front from twelve to sixteen years, during which the presidency would formally alternate between parties. Both parties agreed to the amended plan for the National front as well as Lleras' candidacy for president, and he became president on 7 August 1958.88

President Lleras attempted to end the violence following a course of action which Rojas had also employed during his initial period of rule, that is, the use of an amnesty program to overcome guerrilla activity. Legislative Decree 328 of 20 November 1958 was issued as an amnesty measure, addressing acts of violence which had been committed prior to October 1958. It empowered the governors of departments still affected by the violence to suspend the prosecution of persons and hear petitions for amnesty. Levels of violence began to subside, and as an indicator, deaths attributed to la violencia dropped from 5,342 in 1958, to 3,240 in 1959, and by 1960 the total number was 2,621. 89 Yet, while the amnesty program contributed to the reduction of violence, the government enacted other programs to help reduce the violence. 
The ruling junta established on 27 May 1958 the Investigating Commission Concerning the Present Causes of Violence, which included members of both political parties, along with representatives from the Church and army. 90 The Commission conducted research on $1 \mathrm{a}$ violencia as well as assisting in setting up truces and peace pacts between guerrilla groups and the government. President Lleras adopted one recommendation from the Commission when he established an Office of Rehabilitation. This organization continued the peace efforts of the Commission and created assistance teams to help the victims of violence. Also, it granted loans to former guerrilla leaders to help them re-establish themselves and their followers in agriculture. However, this program was hampered by a lack of funds as well as personnel and administrative problems. 91

The government also established a twenty-man commission in September 1960, to examine existing and proposed land reform legislation. This study led to the passage of the Social Agrarian Reform Law of 1961 on 13 December 1961. Law 135, as it was known, emphasized the distribution of large landholdings to campesinos who were without land or owned only a very small parcel. Lands that were used for distribution included first, publicly owned lands that were suitable to be divided; and then, only if needed, uncultivated, or poorly cultivated private lands. 92 Owners whose lands were expropriated were permitted to retain one hundred hectares (247 acres) of productive land or two hundred and twenty hectares (543 acres) of semi-productive land, with the government acquiring the surplus land by purchase in 
cash and bonds. 93 Only moderate gains of land reform were made as INCORA was beset by lack of adequately trained personnel, budgetary problems, and civil litigation to prevent the government from appropriating privately owned land. 94 It is significant, though, that the first serious attempt at land reform since 1936 should have been one of the measures designed to complete the eradication of la violencia.

As has been seen, by the early 1950s the levels of violence were significantly lower, but "peace" still had not been achieved. The violence had evolved through various stages: (1) political reprisals and family-feuding (1946-1948); (2) a series of rural guerrilla wars (1948-1957); and finally, (3) the establishment and growth of rural banditry from 1957 until the end of la vialencia in mid-1965.

Throughout the history of la violencia, the governments in power established various programs to aid in reducing the levels of violence. One program which has not yet been considered is that of military civic action. The historical development of civic action in Colombia and the role it played in the government's drive to end la violencia will be the topic of the next section. 
Notes

TGermán Guzmán Campos, Orlando Fals Borda, and Eduardo Umaña Luna, La violencia en Colombia: Estudio de un proceso social, $2 d$ ed. (Bogotá: Ediciones Tercer Mundo, 1962), p. 292.

${ }^{2}$ Russell W. Ramsey, "The Modern Violence in Colombia, 1946-1965" (Ph.D. dissertation, University of Florida, Gainesville, 1970), p. 449).

${ }^{3}$ E. J. Hobsbawn, "The Anatomy of Violence," New Society (11 April 1963): 16.

${ }^{4}$ Guzmán, Fals Borda, and Umaña Luna, La violencia, p. 294.

5 James L. Payne, Patterns of Conflict in Colombia (New Haven, Connecticut: Yale University Press, 1968), p. 4.

6avid Bushnell, "Andean South America to Mid-Century: Consolidation of a New Order," Gainesville, Florida, n.d. (Xeroxed.)

7 Robert H. Dix, Colombia: The Political Dimensions of Change (New Haven, Connecticut: Yale University Press, 1967), p. 274.

8 Ibid., p. 80 .

9 Vernon Lee Fluharty, Dance of the Millions: Military Rule and the Social Revolution in Colombia, 1930-1956 (Pittsburgh, Pennsylvania: University of Pittsburgh Press, 1957), p. 30.

10 Ibid., p. 31.

11 Stephan J. Randal1, The Diplomacy of Modernization: Colombian-American Relations, 1920-1940 (Toronto: University of Toronto Press, 1977), p. 56.

${ }^{12}$ Dix, Colombia, p. 80.

13 John Walton, Reluctant Rebels: Comparative Studies of Revolution and Underdevelopment (New York: Columbia University, 1984), p. 85 .

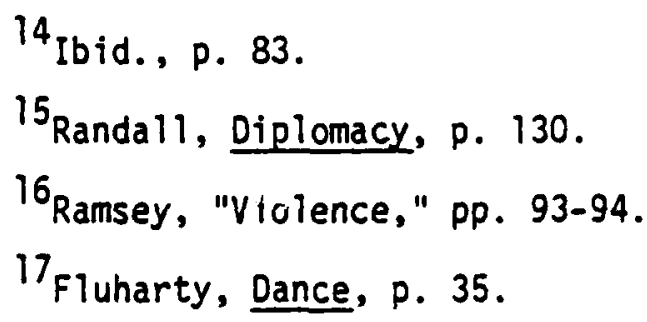


18 Ramsey, "Violence," pp. 95-96.

19 James M. Daniel, Rural Violence in Colombia since 1946 (Washington, D.C.: Special Operations Research Office, American University, May 1965), p. 26.

20 Ibid.

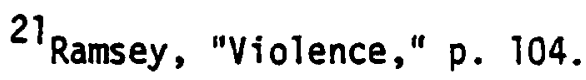

22Danie1, Rural Violence, p. 27.

23 Fluharty, Dance, p. 52.

${ }^{24}$ Howard I. Blustein et al., Area Handbook for Colombia

(Washington, D.C.: U.S. Government Printing Office, 1977), p. 80.

${ }^{25}$ Dix, Colombia, p. 80.

26 William Marion Gibson, The Constitutions of Colombia (Durham, North Carolina: Duke University Press, 1948), p. 369.

27 Fluharty, Dance, p. 52.

28 Ibid., p. 53.

${ }^{29}$ Daniel, Rural Violence, p. 29.

${ }^{30}$ Dix, Colombia, pp. 87-88.

31 Fluharty, Dance, p. 57.

32 John D. Martz, Colombia: A Contemporary Political Survey (Chapel Hill, North Carolina: The University of North Carolina Press, 1962), p. 35.

${ }^{33}$ Dix, Colombia, p. 91.

${ }^{34}$ Daniel, Rural Violence, p. 30.

35 Martz, Colombia, pp. 36-37.

${ }^{36}$ Fluharty, Dance, p. 62.

37 Ibid., pp. 71-72.

${ }^{38}$ Robert William Studer, "The Colombian Army: Political Aspects of Its Role" (Ph.D. dissertation, University of Southern California, Los Angeles, 1975), pp. 77-78. 
${ }^{39}$ James David Henderson, "Origins of the Violencia in Colombia" (Ph.D. dissertation, Texas Christian University, Forth Worth, 1972), p. 140 .

40 Martz, Colombia, pp. 45-46.

41 Henderson, "Origins of the Violencia," p. 144.

${ }^{42}$ Germán Arciniegas, The State of Latin America (New York:

Alfred A. Knopf, 1952), p. 160 .

${ }^{43}$ Ramsey, "Violence," p. 121.

${ }^{44}$ Arciniegas, Latin America, pp. 160-161.

${ }^{45}$ Richard L. Maullin, Soldiers, Guerrillas, and Politics in Colombia (Lexington, Massachusetts: Lexington Books, 1973), p. 82.

${ }^{46}$ Ramsey, "Violence," pp. 121-122.

${ }^{47}$ Henderson, "Origins of the Violencia," p. 145.

48 Martz, Colombia, p. 52.

${ }^{49}$ Henderson, "Origins of the Violencia," p. 167.

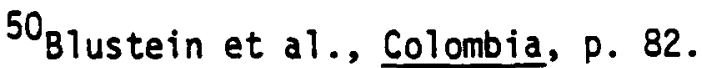

51 Daniel, Rural Violence, p. 42.

52 Harry Kantor, Patterns of Politics and Political Systems in Latin America (Chicago: Rand McNally \& Company, 1969), p. 399.

53 Russell W. Ramsey, Civil-Military Relations in Colombia, 1946-1965 (n.p.: Regent Pub lishing Company, Inc., 1978), p. 2 .

54 Kantor, Patterns of Politics, p. 399.

${ }^{55}$ paul H. Oquist, Violencia, conflicto, y politica en Colombia (Bogota: Instituto de Estudios Colombianos, 1978), pp. 236-237.

56 Ibid., pp. 237-239.

57 Ramsey, Civil-Military Relations, p. 2.

58 Daniel, Rural Violence, p. 63.

59 Ibid., p. 62. 
60 Blustein et al., Colombia, p. 83.

61 Martz, Colombia, p. 116.

62 John C. Pollock, "Violence, Politics, and Elite Performance: The Political Sociology of La Violencia in Colombia," Studies in Comparative International Development 10 (Summer 1975): 37.

${ }^{63}$ Dix, Colombia, p. 109.

64 Ibid., p. 110.

${ }^{65}$ Fluharty, Dance, pp. 123-124.

66 Martz, Colombia, pp. 139-140.

67 Dix, Colombia, pp. 112-113.

${ }^{68}$ Guzmán, Fals Borda, and Umaña Luna, La violencia, pp. 162-163.

69 Walton, Reluctant Rebels, p. 91.

$70_{\text {Dix, Colombia, }}$ p. 366.

${ }^{71} \mathrm{~J}$. Mark Ruhl, "The Military," in Politics of Compromise: Coalition Government in Colombia, ed. R. Albert Berry, Ronald G. Hellman, and Mauricio Solsun (New Brunswick, New Jersey: Transaction Books, 1980), p. 186.

72 Ramsey, "Violence," p. 268.

${ }^{73}$ Dix, Colombia, p. 117.

${ }^{74}$ Guzmán, Fals Borda, and Umaña Luna, La violencia, p. 100.

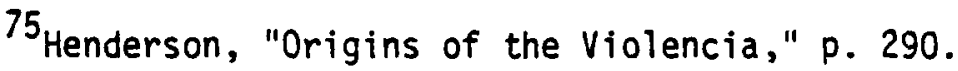

76 Ibid., p. 292.

${ }^{77}$ Daniel, Rural Violence, p. 83.

78 Martz, Colombia, p. 194.

${ }^{79}$ Dix, Colombia, p. 119.

${ }^{80}$ Studer, "The Colombian Army," p. 135.

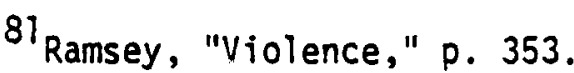


${ }^{82}$ Gonzalo Sánchez and Donny Meertens, Bandoleros, gamonales, $y$ campesinos: El caso de la violencia en Colombia (Bogotá: El Ancora Editores, 1983), p. 199.

${ }^{83}$ Guzmán, Fals Borda, and Umaña Luna, La violencia, p. 281.

${ }^{84}$ Norman A. Bailey, "La Violencia in Colombia," Journal of Inter-American Studies 9 (October 1967): 567.

${ }^{85}$ Dix, Colombia, pp. 371-373.

86 Ibid., p. 133.

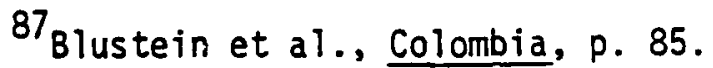

${ }^{88}$ Dix, Colombia, pp. 135-136.

${ }^{89}$ Joan E. Garcés, "Structural Obstacles to the Development of Revolutionary Political Forces in Colombia," Government and Opposition 6 (Summer 1971): 318.

${ }^{90}$ Sánchez and Mertens, La violencia en Colombia, p. 192.

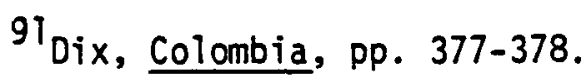

92 Ibid. , pp. 155-156.

930aniel, Rural Violence, p. 111.

94 Blustein et al., Colombia, p. 352. 


\section{MILITARY CIVIC ACTION}

IN COLOMBIA

The adoption of a formal military civic action program in Colombia came in 1963 during the United States government drive to support the concept. Colombia was one of the earliest nations in Latin America to establish a civic action program, following close behind Guatemala (1960) and Ecuador (1962). The internal conditions in Colombia during this period presented United States planners with an almost "textbook" example of factors that favored the employment of civic action programs to assist in national development. Specifically, they could help in the nation-building effort, as well as helping to defeat guerrilla activity. Moreover, as with most nations in the hemisphere, the civic action concept was neither a new nor completely foreign idea for Colombia. The use of the military to assist in national development had been present in Colombia throughout its history.

During the nineteenth century the military institution was kept to minimal size as a means to limit its involvement in national politics. The peacetime standing army, during this period, fluctuated in size between one and two thousand men. The military was used in a variety of civic-type duties, such as transporting the mails and the guarding of prisons and leprosy asylums. This was done as a means to help hold down governmental costs. ' However, with the 
end of the War of a Thousand Days, the military's civic action mission would be greatly expanded, as in January 1905 President Rafael Reyes began to employ the military in public construction projects. Reyes told the troops departing for such services, "Go with tranquil and satisfied hearts because you go not to kill brothers but to irrigate the country's workfields with your sweat."2 The army was used to build roads and bridges; to rebuild war-damaged convents, churches, and hospitals; and to provide protection and labor for a governmentsponsored colonization project in the plains of Meta. ${ }^{3}$ According to one student of Colombian history:

Under Rafael Reyes the army was given a new direction. For the first time, as a matter of government policy, the entire army was dedicated to civic action projects. These projects not only helped in the reconstruction of the country after the Thousand Days' War but also served to bring the national government to the people.4

While President Reyes pointed the army in the direction of civic action in the early twentieth century, this initial impetus was not sustained by the following Conservative administrations. The Conservatives remained in power until 1930 and used the army as a means to supplement the police force in maintaining public order. The military was not deployed according to a military plan, but rather was used to answer calls for assistance from public officials and provide escort for them when required. 5 The use of the military to maintain public order was clearly demonstrated by its role in breaking the strike against the United Fruit Company in 1928. However, with the assumption of power by the Liberal Party in 1930 and in the 
aftermath of the Leticia Conflict with Peru, the government would again bring about a change in mission orientation of the army.

This change became clear in 1935 when President Alfonso Lopez declared that Colombian society could not afford an army that did not have social utility during peacetime. ${ }^{6}$ A civic or developmental mission was therefore assigned in the form of the army opening up new regions in the nation for colonization. In effect, the army was to help change the physical character of the nation. The assignment of the colonization mission to the army may have had political motivations as well, since according to $\mathrm{J}$. Mark Ruhi this use of the military was nothing more than an attempt to divert the military from any political involvements. ${ }^{7}$ In addition, President Lopez created a National Police force with a Liberal orientation to act as a counterweight to the military.

The use of the military in a colonization mission that strictly speaking could be termed non-military but was a perfect example of civic action led to dissatisfaction among the predominantly Conservative officer corps. ${ }^{8}$ This feeling was heightened because of the recent victory over Peru in the Leticia Conflict, as many officers felt that the mission in question was a retrograde step in the army's professional development. Relations with the Liberal administration worsened to such an extent that in 1936 several officers organized an unsuccessful coup against President López. 9 Thus military leadership was generally unsupportive of civic action projects during these years. This point is worth noting, because in 
the 1960 s the reverse was true, with the principal military leadership quite supportive of the civic action concept and prepared to see it as part of a plan of action to combat la violencia.

The outbreak of the violence in 1946 had caused the civic action concept to be temporarily shelved. The military was required to fight Liberal guerrillas and protect the Conservative regimes of Ospina Pêrez and Gómez. However, Gómez by sending combat forces (one reinforced infantry battalion and naval frigate) to assist the U.N. forces fighting in Korea perhaps inadvertently "sowed the seed" for the future civic action programs in the nation. Specifically, the future Minister of War and leading proponent of civic action in the nation during the early 1960s, Lteutenant Colonel Alberto Ruiz Novoa, served as the second commander of the Colombian battalion from 4 July 1952 to 24 June 1953. ${ }^{10}$ While the formal U.S.-sponsored Armed Forces Assistance to Korea (AFAK) program was not initiated until November 1953, the United States did provide unofficial technical assistance for civic action efforts during the combat tour of Lieutenant Colonel Ruiz Novod. There is no formal evidence in his writings at the time such as his Enseñanzas de la campaña de Corea, that he was influenced by the pre-AFAK civic action projects. But the fact remains that he was in Korea when the AFAK concept began, and he may well have noted what military forces were capable of doing to assist a nation's development.

A civic action program was not formally launched in Colombia until 1963. Its adoption then, while due in large part to the 
advocacy of General Ruiz Novoa, also reflected the United States effort to "export" the civic action concept.

\section{Antecedents of U.S.-Colombian Military Cooperation}

Military assistance ties had been formally established between the United States and Colombia with the signing of a Mutual Defense Agreement on 17 April 1952. ${ }^{11}$ Yet even before this agreement the Unjted States had provided Colombia various kinds of military aid and training beginning in the late nineteenth century.

Colombia received its first United States military advisor, Lieutenant Henry H. Lemly, in 1890. Lieutenant Lemly served as an instructor for three years at the national military school, although his position was never formally recognized as a military mission. 12 The Colombian government did not request a second United States Army mission until 1929. Reasons for this delay included strained U.S.Colombian relations over the loss of Panama; U.S. involvement in World War I; and; finally, the preeminence of the European powers in establishing missions in the hemisphere. The Colombian government's request in 1929 was for a United States Army mission composed of officers from the U.S. Army Engineer Corps to survey the proposed work and cost of a planned dredging operation in the Magdalena River. ${ }^{13}$ Interestingly, while U.S. Public Law 247, which had been passed on 19 May 1926, permitted the President to send military personnel to the governments in Latin America, it permitted missions only for "military and naval matters." 14 In reviewing the Colombian request, the Judge Advocate General ruled that it did not fall within the legal framework 
of the law, and if the engineer mission was to be sent, an amendment would be needed. 15 Therefore, the United States falled to provide the technical assistance for a project that could have developed into a civic action program if it had been properly supported by the United States.

Colombia next requested military assistance from the United States in 1932 as a means to help overcome the strength of the Peruvian army. Wanting to maintain a neutral stance in the Leticia Conflict, the United States refused official assistance. However, the United States permitted Colombia to hire eight officers and fourteen enlisted men from the United States Army Air Corps Reserve to train its own air forces. The contract for this "unofficial" training mission was for only six months, but two officers and six enlisted men remained until September 1937. 16

Formal U.S. military training missions were established in Colombia in 1938, during the first year of President Eduardo Santos' administration. President Santos sought a U.S. naval mission to replace a British mission, as it was believed the U.S. was making greater naval technical advances and had greater facilities to support naval forces. In light of the successful role the unofficial U.S. air mission had played in helping to train the Colombian Air Force, the Colombian request was expanded to include an air mission as well. Both military missions were agreed to on 23 November 1938, which officially marked the beginning of U.S. military training assistance to Colombia. 17 
Colombia followed the establishment of these missions with a request for military assistance in additional fields: military intelligence and logistics/administration. The need for improvements in military intelligence stemed from Germany's penetration in Colombia, through its diplomatic mission's intelligence gathering activities as well as concern over German management of the SCADTA airline. Colombia desired logistics training assistance to improve procurement and distribution of supplies. By December 1939 the United States had provided two officers to fill the requested positions. Colonel John W. Lang, who assumed the intelligence advisory role, also made recommendations for changes in the Colombian force structure to that nation's General Staff in January 1940. This reorganization, which was approved by President Santos on 31 January 1940, included reorganization of the military forces into general staff, land forces, air forces, naval forces, and the service support forces; establishment of a quartermaster corps; and the reorganization of the War College. ${ }^{18}$ In addition to technical and advisory assistance, the United States provided Colombia military materiel, although this support began at a later date.

In June 1940, President Santos expressed a desire to Ambassador Braden to purchase military equipment from the United States. President Santos sought to acquire ten naval cutters, sixty to eighty aircraft, 50,000 rifles, as well as other equipment, on terms of financing similar to what the United States was receiving for the purchase of its equipmemt. 19 Ambassador Braden endorsed the 
request, but it was denied, as shipments of war materiel could not be diverted from the West European democracies. ${ }^{20}$ Colombia was forced to wait on any military aid until a lend-lease agreement was signed with the United States on 17 March 1942. The agreement called for the United States to supply defense articles valued at $\$ 16,200,000$, with Colombia agreeing to reimburse the United States for 44.44 percent of the cost of the materiel provided. 21 However, the procurement cost for the defense articles transferred was not the agreed upon total, but only about $\$ 6,000,000$, with the first delivery of materiel coming in February 1944. 22 Colombia also purchased military materiel valued at $\$ 7,570,000$ for $\$ 632,000$ under the terms of the Surplus Property Act of 1944 (Public Law 457, 75th Cong. 2d Sess.), with the materiel being delivered by 30 April 1949. 23 After the expiration of this act in 1949, United States military assistance would not be resumed to Colombia until the passage of the Mutual Security Act of 1951 and the signing of the bilateral agreement on 17 April 1952. Table 3 gives a breakdown by year and amount of U.S. military assistance provided to Colombia from 1952-1970.

An aspect of the military assistance Colombia received from the United States was the training of Colombian personnel at U.S. military schools. Although a variety of U.S. military schools took part, the primary training center for skills needed to support civic action in the 1960s was the U.S. Army School of the Americas (USARSA) located in the former Canal Zone. This school was opened in 1946 as the Latin American Training Center, was redesignated in 1949 the U.S. Army 
Table 3. U.S. military assistance to Colombia 1952-1970

\begin{tabular}{|c|c|c|c|c|}
\hline \multirow[b]{2}{*}{ Year } & \multicolumn{4}{|c|}{ (In Thousands of Dollars) } \\
\hline & $\begin{array}{c}\text { MAP } \\
\text { Program }\end{array}$ & $\begin{array}{l}\text { MAP } \\
\text { Deliveries }\end{array}$ & $\begin{array}{l}\text { IMET MAP } \\
\text { Program }\end{array}$ & $\begin{array}{l}\text { IMET MAP } \\
\text { Deliveries }\end{array}$ \\
\hline $\begin{array}{l}1952 \\
1953 \\
1954 \\
1955 \\
1956 \\
1957 \\
1958 \\
1959 \\
1960 \\
1961 \\
1962 \\
1963 \\
1964 \\
1965 \\
1966 \\
1967 \\
1968 \\
1969 \\
1970\end{array}$ & $\begin{array}{r}3,500 \\
5,200 \\
1,590 \\
1,741 \\
2,511 \\
722 \\
3,797 \\
1,175 \\
4,472 \\
4,178 \\
7,023 \\
5,008 \\
7,245 \\
7,335 \\
10,623 \\
8,350 \\
3,714 \\
2,718 \\
2,046 \\
\end{array}$ & $\begin{array}{r}46 \\
3,409 \\
2,349 \\
3,224 \\
2,113 \\
2,046 \\
2,494 \\
2,356 \\
2,494 \\
2,749 \\
4,177 \\
7,855 \\
5,710 \\
4,637 \\
7,743 \\
7,286 \\
10,342 \\
5,866 \\
3,402 \\
\end{array}$ & $\begin{array}{l}\cdots-- \\
\cdots 110 \\
559 \\
489 \\
385 \\
329 \\
577 \\
390 \\
535 \\
665 \\
159 \\
555 \\
626 \\
755 \\
740 \\
775 \\
790 \\
635 \\
\end{array}$ & $\begin{array}{r}--- \\
108 \\
440 \\
279 \\
216 \\
122 \\
143 \\
234 \\
475 \\
1,626 \\
433 \\
500 \\
555 \\
560 \\
651 \\
1,174 \\
830 \\
536 \\
\end{array}$ \\
\hline TOTAL & 82,948 & 80,298 & 9,074 & 8,882 \\
\hline
\end{tabular}

Source: U.S. Department of Defense Security Assistance Agency, Fiscal Year Series (Wahsington, D.C.: Data Management Division, Comptroller, DSAA, 30 September 1984), pp. 318-319.

Note: MAP = Military Assistance Program; IMET = International Military Education and Training

Caribbean School, and became USARSA in $1963 .^{24}$ Colombia by the end of 1964 ranked fifth among the Latin American nations in total number of military personnel who had graduated from USARSA. ${ }^{25}$ Refer to Table 4 for a breakdown by year and number of Colombian military personnel graduating from USARSA between 1946 and 1970. 
Table 4. Colombian military graduates at the U.S. Army School of the Americas (1946-1970)

\begin{tabular}{|c|c|c|}
\hline Year & Officers & $\begin{array}{l}\text { Enlisted } \\
\text { Personnel }\end{array}$ \\
\hline $\begin{array}{l}1946 \\
1947 \\
1948 \\
1949 \\
1950 \\
1951 \\
1952 \\
1953 \\
1954 \\
1955 \\
1956 \\
1957 \\
1958 \\
1959 \\
1960 \\
1961 \\
1962 \\
1963 \\
1964 \\
1965 \\
1966 \\
1967 \\
1968 \\
1969 \\
1970\end{array}$ & \begin{tabular}{c}
-2 \\
$\cdots--$ \\
\hdashline 13 \\
17 \\
10 \\
30 \\
36 \\
27 \\
57 \\
40 \\
11 \\
9 \\
10 \\
13 \\
14 \\
3 \\
$\cdots-$ \\
6 \\
11 \\
$91^{a}$ \\
$68^{b}$ \\
$158^{2}$ \\
36 \\
\end{tabular} & $\begin{array}{r}-\cdot \\
--- \\
--- \\
--5 \\
71 \\
68 \\
121 \\
276 \\
83 \\
70 \\
81 \\
40 \\
37 \\
26 \\
24 \\
13 \\
50 \\
49 \\
32 \\
56 \\
149 \\
59 \\
101 \\
38 \\
\end{array}$ \\
\hline TOTAL & 600 & 1,453 \\
\hline
\end{tabular}

Source: U.S. Army School of the Americas, Academic Evaluation Reports: Colombia (Fort Benning, Georgia: Author, 1946-1970).

ancludes 80 cadets on two week branch orientation.

b Includes 138 officers who attended one week maintenance orientation. 
In addition to other forms of military aid, the United States provided Colombia technical assistance specifically geared to the support of civic action programs. As mentioned previously, in the 1960s the United States moved to establish mobile training teams (MTTs) consisting of several qualified personnel in their respective specialties (health, engineering, conmunications, etc.) who were sent to a nation as a means to bring the needed technical expertise for civic action. 26 The Colombian civic action program received assistance from several United States MTTs, which will be discussed later, as each segment of the program is discussed.

The principal U.S. military organization for civic action technical assistance to Latin America was the 3d Civil Affairs Detachment, U.S. Army Forces Southern Command, located at Fort Clayton, Canal Zone. 27 Established in October 1962, this unit consisted of only forty officers and thirty enlisted men, but it nevertheless had primary responsibility in this area. ${ }^{28}$ In addition, the 8th Special Forces Group, Airborne, which was located at Fort Gulick, Canal Zone, provided personnel to form MTTs to support civic action programs in the hemisphere. ${ }^{29}$ Though personne? from these two organizations conducted initial civic action feasibility surveys throughout Latin America, this was not the case in Colombia, where the initial survey was completed at a much higher level and at an earlier date than these units were established. 


\section{Establishment and Development of Colombian Military Civic Action Programs}

By 1960-1961 the Colombian military had initiated activities of a civic action nature, such as school construction and the providing of health care. However, these were on a small and regional scale, with no central planning or coordination. ${ }^{30}$ Such was the state of affairs with respect to civic action when the Commanding General of the Colombian Army, Major General Ruiz Novoa, requested that the United States send a Special Warfare (counterinsurgency) MTT to Colombia. The Colombian's request was approved, and an MTT was sent from 2 to 13 February 1962.

In addition to the MTT personnel, Brigadier General William P. Yarborough, Commanding General, U.S. Army Special Warfare Center; the Commanding Officer of the 7th Special Warfare Group, Airborne; and the Deputy for Operations, Plans, and Training, U.S. Army Special Warfare Center accompanied the group to Colombia. Its mission included

1. To evaluate the effectiveness of Colombian counterinsurgency operations with a view to determining qualitative and quantitative requirements for additional special warfare MTTs which the Special Warfare Center might be called upon to provide.

2. To recommend, if asked by the Commander in Chief, Caribbean Command (CINCARIB) or the country team, the amount and type of special warfare assistance which might be furnished to Colombia by the Special Warfare Center.

3. To evaluate the Colombian situation with a view to integrating viable Colombian doctrine and techniques into counterinsurgency instruction presented at the U.S. Anmy Special Warfare School.

4. Based on a specific request from the Colombian Minister of War and the Commanding General of the Colombian 
Army after arrival of the Special Warfare Center Team in Colombia, to develop specific recommendations for improvement of the Colombian counterinsurgency program. 31

Although this MTT was not expressly intended to assess where the Colombian military stood on civic action programs or what programs should be established, it was not expected to overlook the potential for their use by the Colombian military.

The MTT visited four of the Colombian Army brigade sectors, which included areas in the following departments: Tolima, Hui?a, Meta, Antioquia, Caldas, and Choco. ${ }^{32}$ Therefore, the MTT was able to observe areas with relative peace such as Chocó, Meta, and Antioquia, in comparison with areas affected by a high degree of violence: Tolima, Caldas, and Huila (see Table 5). On this basis the MTT provided an estimate of the current status of the Colombian military and its ability to handle the violence. Some of the conclusions were

1. The effectiveness of the Army as well as the effectiveness of the entire Colombian national effort in counterinsurgency is reduced significantly by the absence of any central planning, coordinating, and controlling agency through which all resources can be applied in concert toward solution of the insurgency and banditry problem.

2. Army personnel are being used in civil capacities for which they are not trained adequately and which inhibit their capability to operate against insurgents and bandits.

3. The Army's most serious deficiency is its lack of essential communications to control maneuvering elements and relay timely intelligence, as well as to maintain contact among fixed installations.

4. The Army's "Civic Action" program is sporadic, not prescribed by plan, and only occasionally supported with necessary means.

5. Above and beyond organizational and training deficiencies which are within the power of the Army to correct, 
there are complex political, sociological, and economic factors for which solutions appear remote and which will continue to provide a climate in which dissident banditry and insurgency can grow. 33

Table 5. La violencia death toll (June '957-

\begin{tabular}{|c|c|c|}
\hline & $\begin{array}{l}\text { Department or Region } \\
\text { (Pre-1965 Names) }\end{array}$ & Deaths \\
\hline \multirow[t]{2}{*}{$\begin{array}{l}1 . \\
2 . \\
3 . \\
4 . \\
5 . \\
6 . \\
7 . \\
8 . \\
9 . \\
10 . \\
11 . \\
12 . \\
13 . \\
14 .\end{array}$} & $\begin{array}{l}\text { Antioquia } \\
\text { Bolívar (including Córdoba) } \\
\text { Boyacá } \\
\text { Caldas } \\
\text { Caquetá } \\
\text { Cauca } \\
\text { Cundinamarca } \\
\text { Chocó } \\
\text { Huila } \\
\text { Llanos Orientales (Meta) } \\
\text { Santander } \\
\text { Norte de Santander } \\
\text { Tolima } \\
\text { Valle }\end{array}$ & $\begin{array}{r}450 \\
50 \\
50 \\
5,400 \\
50 \\
2,100 \\
400 \\
50 \\
1,500 \\
350 \\
450 \\
50 \\
6,200 \\
2,300 \\
\end{array}$ \\
\hline & TOTAL & 19,400 \\
\hline
\end{tabular}

Source: Russell W. Ramsey, "The Modern Violence in Colombia, 1946-1965" (Ph.D. dissertation, University of Florida, Gainesville, 1970), p. 449.

In line with these findings, a number of concrete recommendations were made to the Minister of War Major General Hernândez and to Major General Ruiz Novoa at the MTT's departure. The more important included

1. Take the initiative in proposing a national planning, coordinating, and control agency which can make most effective use of all national resources in fighting insurgency and banditry. 
2. Propose a plan for phasing out military personnel now performing civil functions, turning these over, where appropriate, to police. In the meantime, ensure intensive training in civil affairs for Army personnel used in civil capacity.

3. Make increased efforts to correct existing communications deficiencies.

4. Develop an overall plan for the use of Army forces in all aspects of counterinsurgency, and require subordinate commands to prepare and carry out supporting plans.

5. In coordination with the national government, develop an aggressive psychological warfare and troop indoctrination plan, train key personnel to carry out the plan, and provide necessary material support.

6. Develop a comprehensive and feasible civic action program and give the operational elements the necessary conceptual (planning), monetary, and logistical means with which to accomplish their assigned civic action mission. 34

While the senior leadership in the Colombian military was displaying increased interest in counterinsurgency tactics and related civic action, as demonstrated by the request for the U.S. MTT, the administration of newly elected President Guillermo Leon Valencia also showed an interest in the civic action concept. This interest was strongly influenced by a report completed in September 1958 under the direction of French economist-clergyman Louis J. Lebret, Estudio sobre las condiciones del desarrollo de Colombia. ${ }^{35}$ In the section of the report entitled, "Educational Functions of the Armed Forces," the author called for

. . . the optimal utilization of the armed forces to assure harmonious development, particularly in what refers to the more rapid establishment of infrastructure, for the preparation of technicians at different levels for the purpose of exploiting the territory, and for the cultural elevation of the whole. Stated in another form, the armed forces of a 
developing country not on ty have a defensive function: they should also be, according to the eminent French rural

economist, Jean Marious Gatheron, "a creative army." 36

The administration of President Valencia incorporated this concept of a "creative army" (civic action) into the National Front program, which in his administration was named "Programa de los Cuarenta." Included in this program was a specific mission outlined for the military:

The organization, equipping, and technical preparation of the military forces should correspond everyday more decidedly to the importance of their defensive mission and to the contribution which they can provide to national progress in other fields such as in popular education, community development and land reform. 37

A civic action program was worked out between April and September 1962. The United States country team assisted the Colombian military in formulating the plan, which was referred to as an "Impact" program. It stressed the use of civic action projects in areas most affected by the violence and envisioned the construction of roads, community development, health and sanitation projects, water supply improvements, and educational programs. The work would be carried out by Colombian Army Engineer units with assistance from the local populace. After a project was completed, it would then be turned over to community authorities for supervision and maintenance. 38 However, the plan was not immediately adopted, as the Colombian government requested a United States civic action MTT (CAMTT) to study it first. The CAMTT arrived late in the year and evaluated the civic action projects proposed in the "Impact" program as to their potential in assisting to reduce the levels of violence. Those projects 
which were retained came to embody the core of Colombia's civic action (Acción Civica Militar) program. 39

In the months preceding the establishment of a formal national civic action program, the Colombian military did initiate a number of civic action projects. One of these was the Servicio de Aeronavegacion a los Territorios Nacionales (SATENA), established by Presidential Decree No. 940, 12 April 1962, which was a governmentowned and Air Force-operated non-profit airline. This was not an entirely new mission for the Air Force, as since 1930 it had carried mail and provided air transportation to the more remote areas of the south or to the San Andres and Providencia Islands off the coast of Nicaragua. 40 The purpose of SATENA, however, as stated in the decree establishing it, was to serve all underdeveloped regions of Colombia." 41 By improving transport services, it was "to increase the sanitary and educational programs, the communications systems, and the economic development of these regions. "42

Flight operations by SATENA began on 31 July 1962, supported by six aircraft (one C-54, two C-47s, two PBYs, and one L-20). ${ }^{43}$ Air force personnel were detailed to SATENA to operate and maintain the aircraft. Weekly air routes were established to transport passengers and freight to remote areas of the nation such as the Amazonian region and the llanos orientales. These flights helped to integrate isolated inhabitants physically into national life. ${ }^{44}$ By the end of 1964, SATENA had flown 9,250 hours, transported $6,975,903$ pounds of cargo and 43,205 passengers. The United States supported the 
expansion of SATENA in 1964 by providing three $C-47$ and two $C-54$ surplus aircraft to Colombia with Agency for International Development (AID) funding. ${ }^{45}$ Aside from this, SATENA's operations were totally funded by the national government.

The United States Colombian country team during the same initial period of development also assisted the Colombian military in the formation of the counterinsurgency plan known as "Plan Lazo" (noose), which had a significant civic action component. However, to state that the United States advisors played the principal role in the establishment of Plan Lazo would be incorrect. Indeed, the plan was designed by Generals Gabriel Rebeiz and Jaime Fajardo and Colone 1 Alvaro Valencia Tovar. ${ }^{46}$ General Ruiz, who supported the findings of the Lebret Report in regard to the functions of the military in national development, strongly backed the inception and execution of Plan Lazo. ${ }^{47}$

Plan Lazo was initiated on 1 July 1962 as a means to eliminate the so-called "independent republics" created by leftist insurgents and some bandit elements in the upper Magdalena Valley. Plan Lazo encompassed four approaches to the reduction of violence levels:

1. Tightening and integrating the command structure of all forces engaged in public order missions, to clearly establish military responsibility for all operations.

2. Creating more versatile and sophisticated tactical units capable of successful unconventional warfare operations.

3. Expanding the military's public relations and psychological warfare units to improve civilian attitudes toward the army's public order mission. 
4. Employing the armed forces in tasks intended to contribute to the economic development and social well-being of all Colombians especially those subjected to guerrillabandit activity. 48

In accordance with Plan Lazo, in September 1962, the 8th Brigade was activated and assigned a zone of action which included the northern section of Valle; the area of Caldas which later became the new Departments of Quindio and Riseralda; and a small portion of Choco. ${ }^{49}$ In the coffee-producing region of Quindio, the 8th Brigade operated with infantry, artillery, engineer, lancero (ranger-type forces), intelligence, and psychological warfare units. Additionally, bandit cuadrillas were penetrated by specially trained military infiltrators to gain information, reduce the number of attacks, and, if possible, lead the cuadrilla into captivity. ${ }^{50}$ While the use of such forces to fight bandits or guerrillas and protect the populace remained as one of Plan Lazo's early principles, emphasis would slowly shift to the final objective of Plan Lazo, namely, the use of military forces to aid in national development.

As already mentioned, the U.S. CAMTT which arrived in late 1962 evaluated the proposed "Impact" program and recommended the projects to be activated by the Colombian military. While an informal civic action program was adopted at the end of 1962, a formal organization was not established until mid-1963, when, growing out of the recommendation by the U.S. Special Warfare MTT to establish a national control agency for civic action, the Nationai Committee for Military Civic Action (Comité Nacional de Acción Civica Militar) was established by Presidential Decree No. 1381 on 24 June 1963. This 
agency received the mission of coordinating civic action activities throughout the nation. Included in the committee were the ministers of government, war, agriculture, public health, national education, and public works. 51 This, then, was the true beginning of a nationally organized and controlled civic action program in Colombia.

The Impact civic action program established at the end of 1962 encompassed four major areas of development: road construction and maintenance, education, health care, and communications. 52 other civic action projects in which the military would become involved included youth camps, rural electrification projects, potable water supply improvements, and military civic action field days. 53 While all of these projects were underway by 1965, a clear priority was established from an early date for road construction and maintenance.

Road construction received the highest priority because it was seen as a means to penetrate violence-affected areas and establish farm-to-market routes. 54 United States planners found, however, that the Colombian Army Engineer Battalions would have to be reorganized if they were to be used to best advantage on road construction projects. The training methods at the Engineer School were found in need of updating. The engineer battalions were also hampered by a lack of trained heavy equipment operators as well as a shortage of the type of equipment needed to undertake a concerted road construction program. 55 These were problems that needed to be resolved before the road construction program could even get off the ground. 
The Colombian military concurred with U.S. planners as to the importance of the road development program. Accordingly, in February 1963 General Ruiz signed two project agreements with the United States under the titles of "Tolima Highway" and "Road Improvement and Maintenance." 56 The United States further supplied a two-man MTT (Project officer and enlisted technician) to support the program, and in 1963, out of the fifty Colombian Army enlisted personnel who attended the U.S. School of the Americas, sixteen completed engineer-related courses (combat construction engineer and heavy equipment operator). In a related field, thirteen enlisted personnel completed a wheeled vehicle mechanic course. 57 In this way, the Colombian Army moved to utilize the technical training available through U.S. military assistance to improve the skills of soldiers in the engineer units.

The Tolima Highway project began on 10 June 1963 and involved the construction of two all-weather, two-lane gravel highways in the departments of Tolima and Valle, one running east-west and the other north-south (Figure 1). 58 The east-west portion of the project involved ninety-eight miles of construction between Ataco in Tolima Department and Palmira in Valle. The north-south section of the project proceeded south from Chaparral to Santiago Pérez, a distance of about thirty miles. Additionally, short-distance feeder roads linking Gaitania to El Carmen and Pacarni to Río Chiquito were planned. The establishment of the Tolima Highway network would bisect an area of approximately 2,200 square miles, which had been 


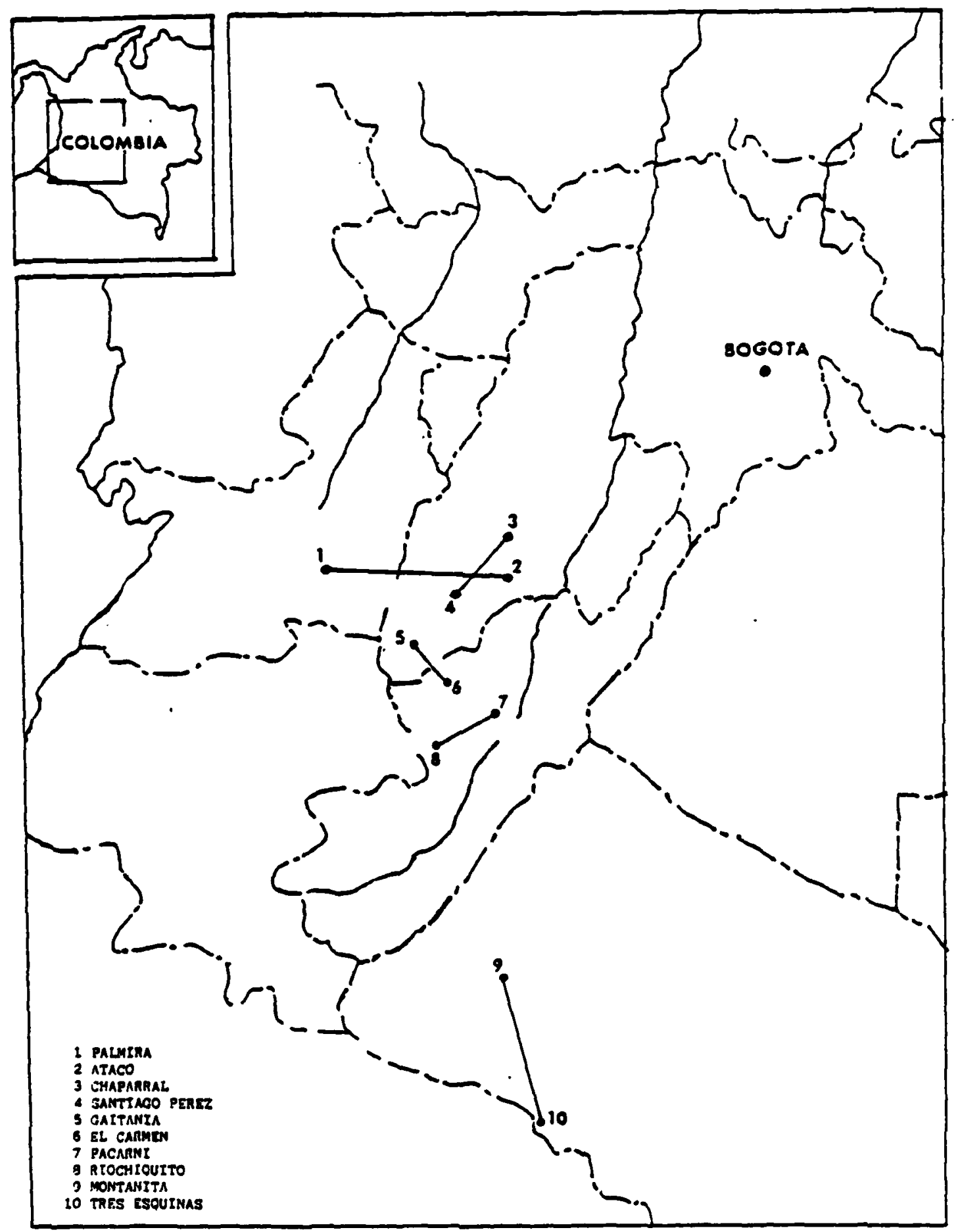

Figure 1. Military road construction projects (1963-1964)

Source: Niorman D. Smith, Howard K. Kaufman, and Charles D. Windle, Effects of liilitary Civic Action on Attitudes: An Empirical Study in Colombia (Washington, D.C.: Center for Research in Social Systems, Amerfcan University, May 1969), p. 21. 
the scene for some of the highest levels of violence. In FY 1963 United States support to this project was $\$ 400,000$, provided through AID funds. These funds were used to purchase construction supplies, fuel, and lubricants. In FY 1964 an additional $\$ 224,000$ was provided by AID funds to purchase consumable supplies. 59 Equipment to outfit the three Engineer Battalions involved in the project was provided by MAP funds during FY 1964-1966. By the end of 1964, approximately seventy-two miles of the original project were completed, with the Public Works Department assuming a maintenance responsibility for twenty miles. 60

A second road project (Codename: "Orion"), not directly supported by the United States, was the construction of a fifty-eight mile road linking Tres Esquinas and Montanita (Figure 1). This project was assigned to the Colombian Air Force to supervise, since the Air Force had a base at Tres Esquinas. Being the only governmental agency in the area, it could act as the executive agency for the project. Project Orion was begun in late 1963 as a means to open up the region for colonization and development: products of the region could be transported to Tres Esquinas by river and then shipped by truck to Montanita. Funds for the project were provided by INCORA, the Colombian land reform agency. Progress was slow due to limited resources, rugged terrain, and weather; and by the end of 1964 only seven miles of road bed were constructed. 61

Under the Road Improvement and Maintenance agreement, approximately 700 miles of deteriorated roads were scheduled for repair. Colombian Army Engineers reconditioned roads primarily in 
the Departments of Santander, Caldas, and Valle, where maintenance had been neglected as a result of violence levels. 62 colombian Engineer units involved in the repair work were supported with MAP equipment, but the projects were financed by the national government. By mid-1965, less than 10 percent of the planned repairs had been completed. 63

Although road construction and maintenance programs had the highest priority and received approximately 67 percent of the U.S. AID civic action funding by the end of 1966, progress on the various projects was extremely slow. ${ }^{64}$ As has been discussed, road projects were hindered by lack of qualified personnel to operate the equipment, which in turn was either in short supply or slow in arriving to the units doing the work. Nevertheless, road construction continued to receive emphasis as a means to reduce the violence. In 1965, referring to the Tolima Highway Project, the United States Military Group Commander wrote:

. . its impact is already being felt. The economy of the sector is considerably stronger and the standard of living of the people has improved. Factors contributing to violence are alleviated and security forces gain easier access to zone. This effort has greatly enhanced the public image of the government and its agencies and has assisted in winning the populace over to the size of the governmental forces. Barring unforeseen developments, completion of this road should permit nearly total pacification of this area in the very hear future. 65

Therefore, the U.S. planners' perception on the success rate of road construction in aiding to reduce the violence was quite favorable. Additionaliy, the Colombian military continued to follow a similar position in support of road construction. This is illustrated by the 
Colombian army sending eighty-three enlisted men to attend engineer construction-type or vehicle maintenance courses at USARSA between 1964 and 1967.66

The second major type of civic action project the military was involved in dealt with education. The military assisted in the construction of rural schools and, at the same time, created an armed forces literacy training program. The latter program was established in October 1963 with the objective of reducing illiteracy among the 9,000 recruits annually inducted into the armed forces. 67 This program was modeled after the Guatemalan Army Alphabetization Centers. Electronic equipment, tapes, and booklets were purchased by a grant of $\$ 24,000$ from U.S. AID in October 1963, and learning centers were established at seven Army recruit training centers (Figure 2). 68 This literacy program was designed to provide one hundred hours of literacy training for recruits, of whom roughly 60 percent were illiterate. At the completion of the training, the soldier was expected to reach a third-grade level of reading and writing skills. Learning centers were also established at the Naval Infantry (Marines) Training Center at Cartagena and the Air Force Training Center at Madrid using funds from the original U.S. AID grant. The literacy rate among the recruits rose from 40 percent to 85 percent at the conclusion of the training. ${ }^{69}$ Educational resources were then placed at the battalion levels, so the newly. assigned soldier might continue the learning process. Also, it was hoped that the soldier upon leaving the military might teach a family member or member of his community some of his acquired skills. 70 


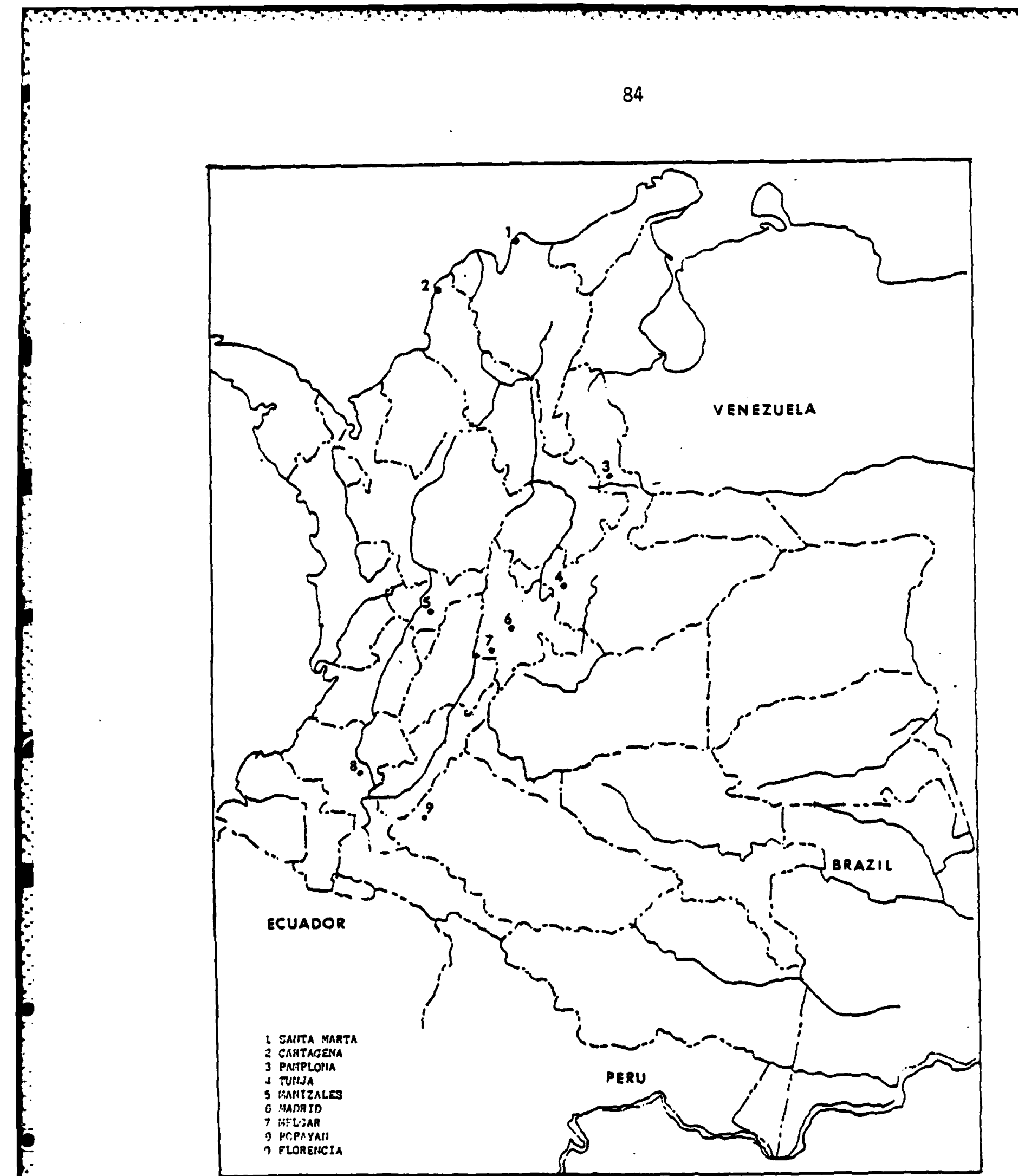

Figure 2. Military literacy training centers

Source: Morman D. Smith, Howard K. Kaufman, and Charles D. Windle, Effects of Military Civic Action on Attitudes: An Empirical Study in Colombia (Washington, D.C.: Center for Research in Social Systems, American University, May 1969), p. 25. 
The literacy program conducted in the armed forces was seen, too, as a means to provide departing servicemen the skills to complete training offered by the National Apprenticeship Service (Servicio Nacional de Aprendizaje-SENA). This organization had been established in 1957 to provide technical training to adult workers already employed. Financing for SENA came from a 2 percent payroll tax on any private business that employed ten or more workers. 71 By 1966 it was anticipated that all ex-servicemen would receive technical training in one of the twenty-seven SENA institutions upon returning to civilian life. However, as SENA was controlled in practice by private industry and there was no formal allocation of school quotas for the military, this aim was realized only in part. 72 Military forces also engaged in rural school construction. This program was initiated by the Colombian Army in 1960-1961, and, as originally planned, army units were to construct the schools using funds from the military's budget as well as from organizations much as INCORA and the National Federation of Coffee Growers (Federacion Nacional de Cafeteros-FEDECAFE). ${ }^{73}$ However, U.S. AID funding was approved, so as to permit a larger scale of operation, and during Fy 1965-1967 $\$ 200,000$ was provided to assist in the construction. 74 Schools were planned for remote and violence-affected areas, the Colombian Army cooperating with the Ministry of Education and local communities to select the locations. ${ }^{75}$ Initially, fifteen schools were programed for construction during 1964-1965, but the project was later expanded to include about twenty schools (Figure 3). 


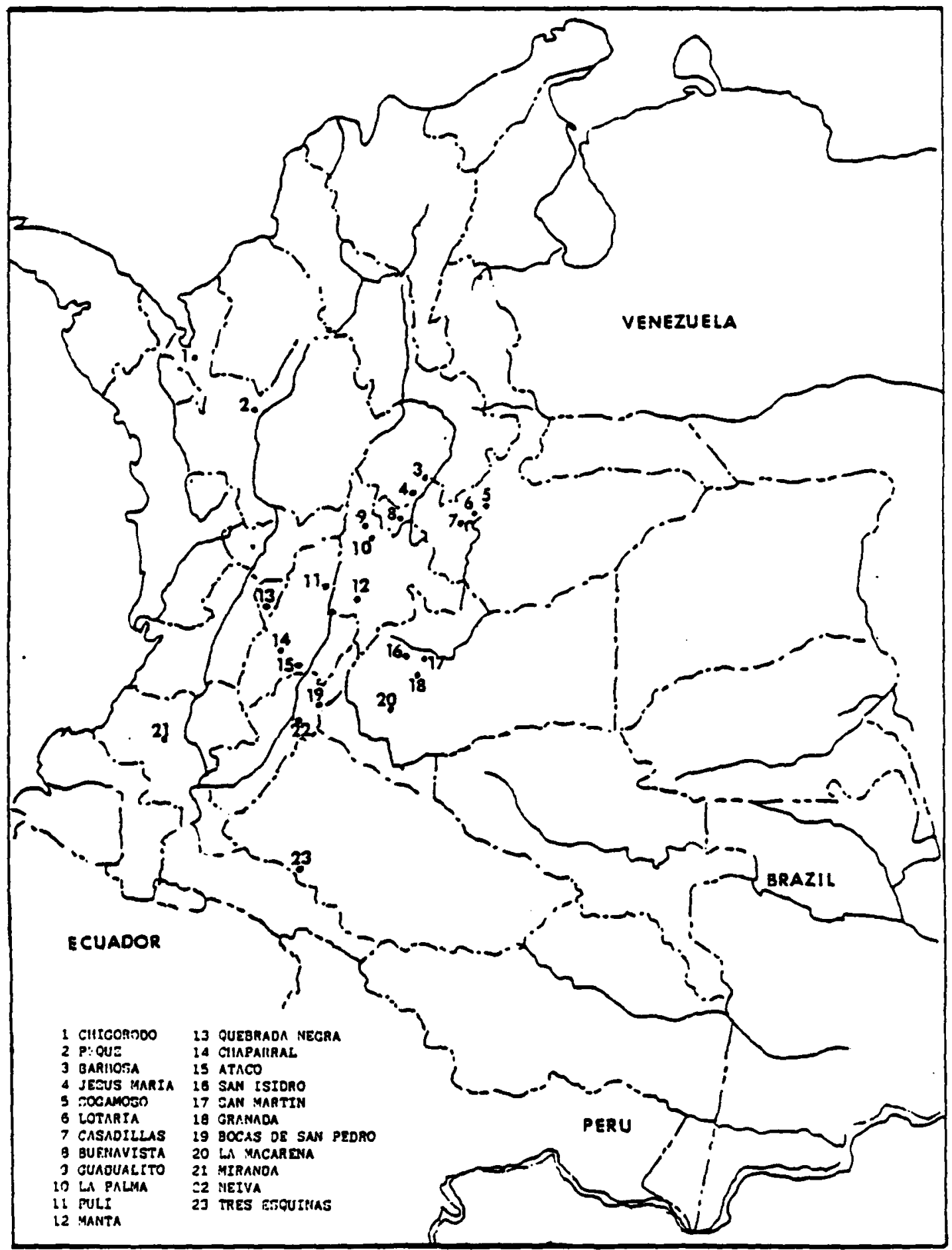

Figure 3. Rural school construction by military forces (1964-1965)

Source: Noman D. Smith, Howard K. Kaufman, and Charles D. Windle, Effects of :ililitary Civic Action on ittitudes: An Empirical Studv in Colombia (Washington, D.C.: Center for Research in Social Systems, American University, May 1969), p. 26. 
The schools were built using military labor in addition to civilian workers when possible. They consisted of one or two classrooms and living quarters for the teachers. Approximate value for each school constructed was $\$ 3,000.76$ The military would not sponsor school construction; however, unless two conditions were met. First, a contract had to be signed by the local community, which indicated its desire to establish a school and willingness to assist with labor. Secondly, the Ministry of Education had to agree to maintain the school after completion. 77 The support of the army for school construction in remote and violence-affected areas did not stop with the der.line of 19 violencia and after 1965 an average of thirty schools per year were built by the army until 1968. ${ }^{78}$ The number constructed by the army is still small in relation to the government's total effort in school construction, but schools were brought to areas that otherwise would not even have had the possibility of a school. 79

The Army's educational development effort aiso featured a civic action project known as the "Youth Camp" program. This program, which initially involved only the Colombian Army, began in July 1964 assisted by a $\$ 3,000$ grant from AIJ funds. The pilct program consisted of four camps located nar military installations at Tunja, Armenia, Palmira, and Neiva. ${ }^{80}$ I: called for a voluntary three-week encampment for fifty boys, ages thirteen to fifteen, at each camp site. Each of the pilot camps, with the possible exception of Tunja, was held in an active or potential violence-affected area. Participants 
were exposed to a program of instruction consisting of courses on Colombian history, government, geography, patriotic songs, sanitation, ethics, horticulture, religion, group activities, and sports. Additionally, visits were conducted to historical sites, industrial plants, government offices, churches, universities, and other military installations. Instruction was provided by Colombian Army officers and non-cormissioned officers, doctors, priests, and Peace Corps personnel. Also, each youth received two changes of clothing, a pair of shoes, and a food package provided by CARE. Yet average cost for each participant was only $\$ 20.81$

In late 1964, with support from President Valencia, the program grew to include twenty camps; of those, sixteen were conducted by the Army, while the Navy conducted camps at the Naval Training Center at Barranquilla and the Naval Base, Cartagena, and the Air Force conducted camps at the Melgar and Palanquero air bases (Figure 4). Funding for the expanded camp program was approximately $\$ 19,000$, provided by the Colombian government. Although no U.S. AID funds were provided for 1965, $\$ 81,000$ was allocated for 1966 to assist in still further expansion of the program. 82 By 1968, there were forty-three youth camps, and one year later fifty-seven. 83 The rapid expansion of the youth camp program demonstrated the extent of support given by the military as well as the national government. In addition, the positive popular reception of the program is indicated by the fact that by 1965 there was approximately a 200 percent excess of youth volunteers. 84 The youth camp program thus proved to be a valuable adjunct to the military's rural school construction activities. 


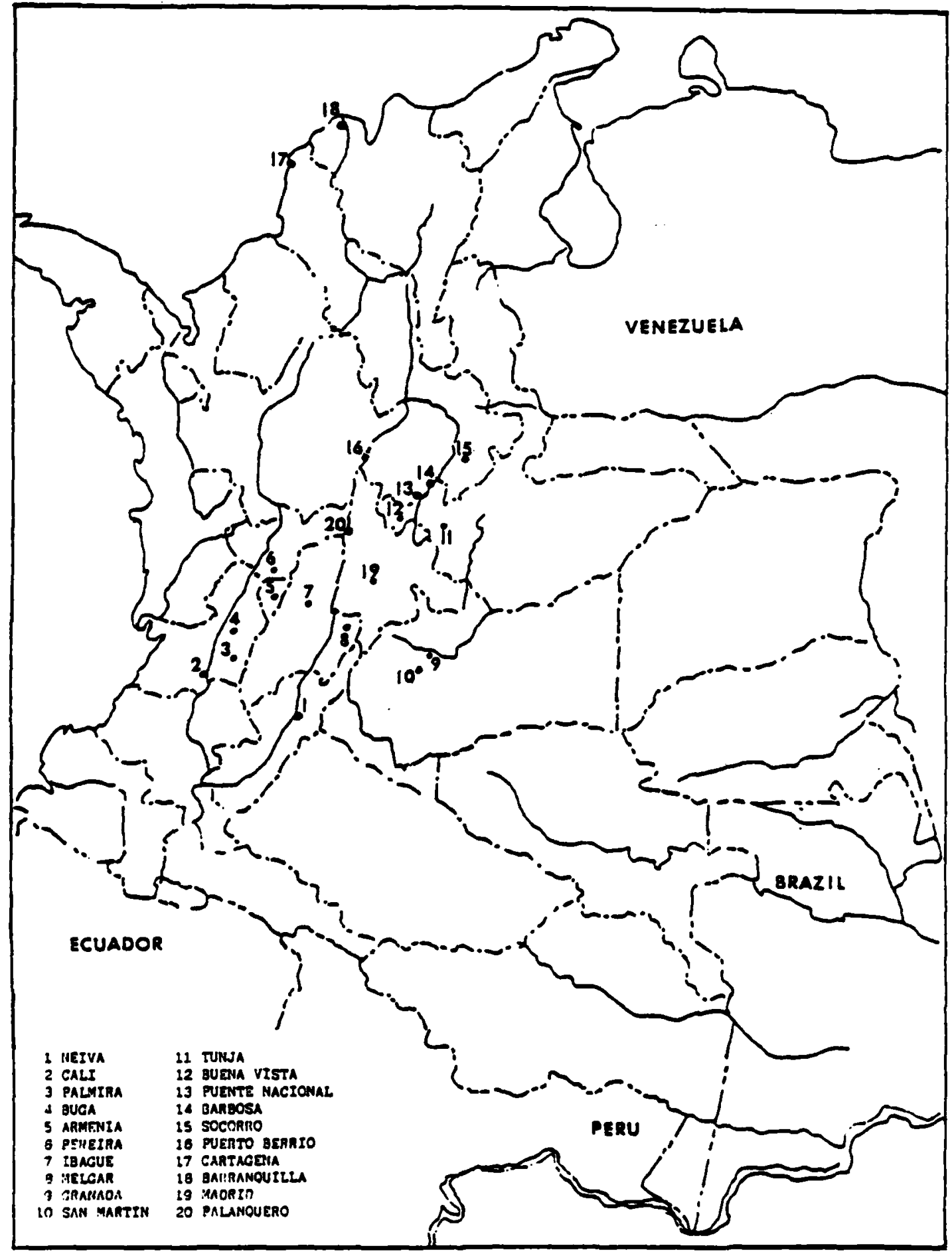

Figure 4. Military youth camps (1964)

Source: Norman D. Smith, Howard K. Kaufman, and Charles D. Windle, Effects of Military Civic Action on Attitudes: An Empirical Study in Colombia (Washington, 0.C.: Center for Research in Social Systems, American University, May 1969), p. 28. 
In February 1964 the medical health center program was established to provide preventive medicine, minor surgery, and dental treatment for the estimated 100,000 persons who were living in remote or violence-affected areas. 85 This was one of the primary programs recommended by the U.S. CAMTT to the Colombian military at the end of 1962. Originally, twelve locations were selected, but due to the availability of sufficient medical equipment the program was expanded to include nineteen sites (Figure 5). Funding for this program came from several sources. First, the medical equipment for each dispensary, valued at about $\$ 17,000$ ( $\$ 323,000$ total) was provided by the U.S. Military Assistance Program. Secondly, consumable supplies in the amount of $\$ 157,000$ were provided by U.S. AID. At the same time, 1,080,000 Colombian pesos were diverted from the 1964 U.S. AID Program Loan Fund. 86 No major. construction of buildings was planned, as local communities or other governmental agencies furnished the new facilities. Personnel involved in the program included one U.S. officer; seven officers and twenty-nine enlisted men of the Colombian military; and forty civilians (doctor, dentists, and nurses). Within six months of the program's establishment, approximately 52,000 persons were treated. 87 The health center project also received support from a U.S. CAMTT, which arrived in March 1964 to assist in the training and help set up organizational procedure for staff members of the new health centers. Of the three U.S. officers in the CAMTT, one was a female dietician, the first woman to be sent to a Latin American nation to assist in civic action. 88 


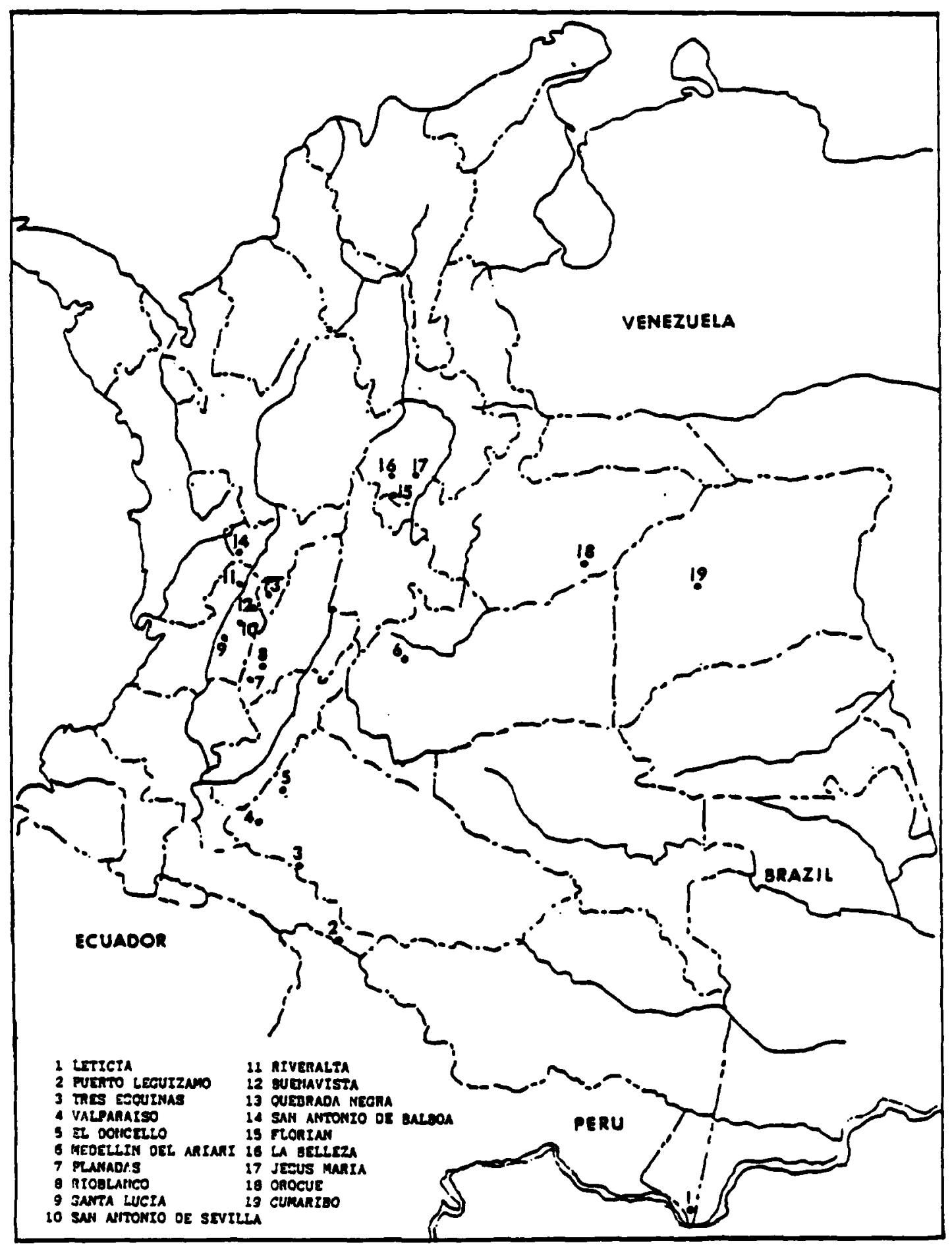

Figure 5. Military sponsored health clinics

Source: Norman D. Smith, Howard K. Kaufman, and Charles D. Windle, Effects of Military Civic Action on Attitudes: An Empirical Study in Colombia (Washington, D.C.: Center for hesearch in Social Systeris, American University, May 1969), p. 30. 
In addition to the fixed-site health centers, the Air Force established a "Flying Dispensary." The Air Force equipped a PBY aircraft with U.S. MAP-supplied surgical, dental, and medical kits. This operation, though formally established on 7 July 1964, did not begin operations until 19 October 1964 due to a delay in the refurbishment of the aircraft. The Flying Dispensary was used to reach isolated and underdeveloped regions of the nation, where it brought vitally needed medical services to the indigenous population as well as to the colonists. ${ }^{89}$ The first three visits by the aircraft resulted in 422 medical consultations, 283 vaccinations and 87 dental extractions. 90 In much the same way, the Colombian Navy provided health care through the establishment of two "floating dispensaries," one on the Magdalena and the other along the Putumayo River. 91 These dispensaries provided basic health care similar to that of the fixed health centers.

The health centers were perceived by U.S. and Colombian planners as a positive influence toward reduction of the violence, as well as providing a needed and basic service to the population in less developed regions of the nation. United States Army Colonel joy K. Vallery, observed concerning the program:

It is justified not only by humanitarian concepts, but also by practical political considerations. The standards of health of the rural populace are low, and the dispensaries meet a critical requirement for improving those standards. Further, the dispensaries provide evidence of the concern and interest of the government and its agencies; creating an atmosphere conducive to mutual cooperation and maintenance of public order and stability. 92 
The health centers proved to be a central segment of the Colombian military's civic action throughout the 1960s.

The Colombian military also sought to improve sanitation conditions by providing a potable water supply to those communities in remote and violence-affected areas that had an insufficient or polluted source of water. 93 The potable water supply project began on 6 August 1963. Support was provided through U.S. MAP in the form of three well-drilling rigs as well as the necessary equipment to outfit three well-drilling teams. A United States CAMTT (one officer and one non-commissioned officer) which lasted six months, trained Colombian Army personnel in well-drilling operations. 94 Additionally, U.S. AID supplied $\$ 223,000$ in grant funds during 1964-1965, and 709,000 Colombian pesos from the 1964 Program Loan Fund for spare parts, drill points, chlorinators, filters, and well casing. ${ }^{95}$ By the end of 1965 , twenty-five water wells were completed and in production in those areas targeted by the military as needing the assistance. 96

The fourth major area of military civic action was communications, involving mainly two separate communication projects. First, to improve communications between the national government and the most distant locations in the nation, a National Territory Radio Network was established in January 1963. This radio network was formed under the control of the Office of Public Safety, but technical assistance to support operations was provided by the Colombian Ministry of War. The network consisted of l-kilowatt single-side-band (SSB) radio stations located at a variety of sites (Figure 6). Additionally, 100 -watt radio stations were established as 


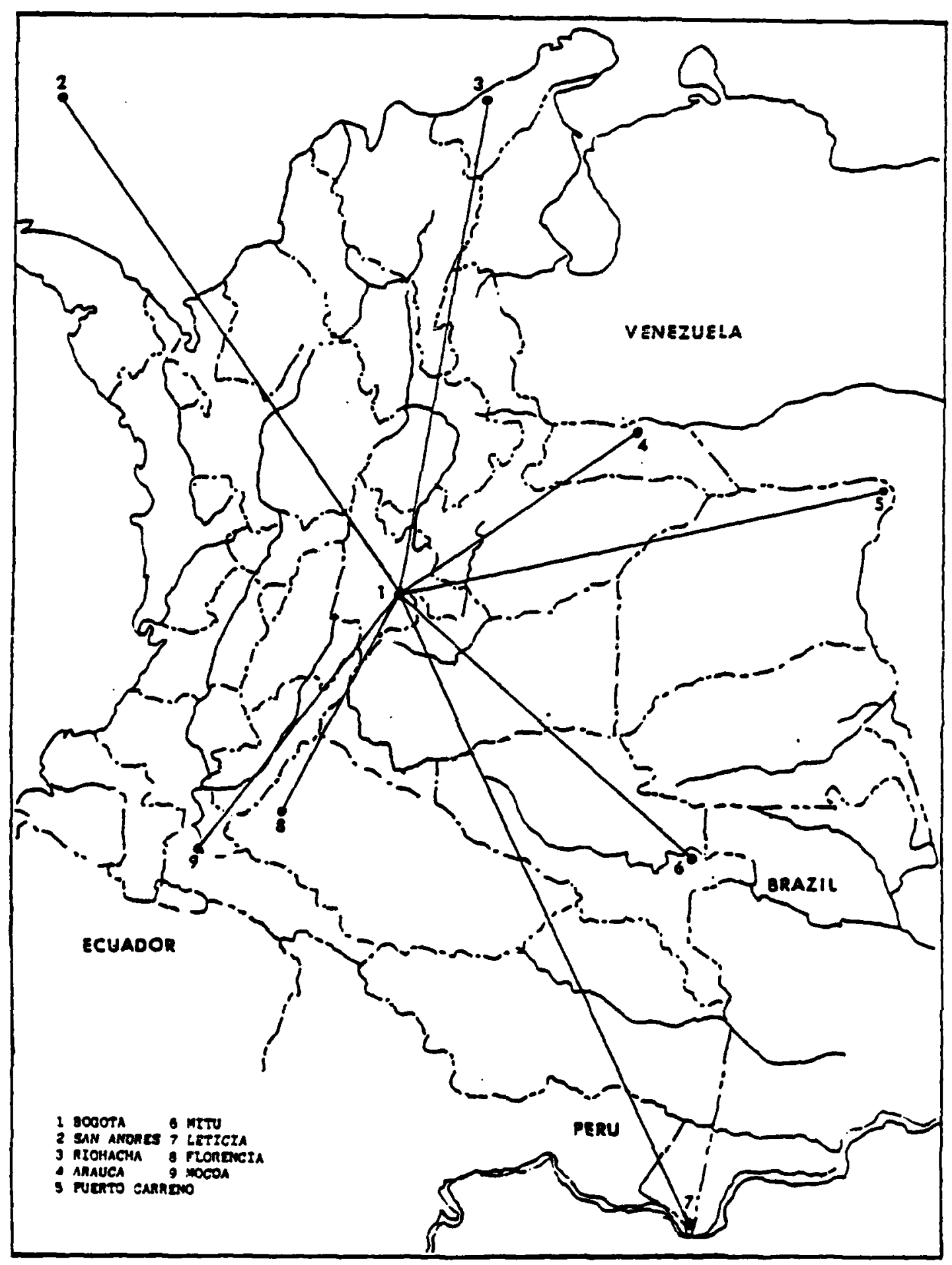

Figure 6. Colombian national territory radio network (1-kilowatt SSB radio stations)

Source: Norman D. Smith, Howard K. Kaufman, and Charles D. Windle, Effects of Military Civic Action on Attitudes: An Empirical Study in Colombia (Washington, D.C.: Center for Research in Social Systems, American Univeristy, May 1969), p. 32. 
satellite stations to the primary radio stations. Funding for this prc an came from the national government in addition to $\$ 732,000$ provided by U.S. AID in February 1963 for the purchase of twenty-eight 100-watt SSB radio stations. 97 These stations helped to tie the remote areas closer to the national government and facilitated a greater degree of cooperation between the inhabitants of these areas and military forces, which contributed to improved security operations. 98

The second cormunication project to be established was an early warning or civil defense net. These civil defense nets came to be called the finca nets, as they were formed to provide emergency communications between farming settlements (fincas) and security forces. The program had been planned by Colombian Air Force Lieutenant Colonel Hernando Nieto prior to the arrival of the first U.S. CAMTT but had not been initiated due to a lack of funds. It became operational in early 1965, after U.S. AID funds in the amount of 500,000 pesos were provided from the 1964 Program Loan Fund to purchase the needed control and relay equipment. ${ }^{99}$ However, individual civilians contributed approximately US\$200 for the purchase of equipment which provided them with a communication capacity on one of the finca nets. 100 The eleven finca nets consisted of approximately one thousand individual small radio units which could communicate with any other station on any one of the different finca nets. The establishment of the different cormunication systems, although aimed at assisting security operations, helped in Colombia's 
general development, by making available reasonably reliable and rapid means of communications.

Other significant civic action projects by the military included a rural electrification project and military civic action days. The rural electrification project, supported by the Army, began in 1964 and involved the establishment of portable lighting systems (5-30 kW) in small strategically located villages. The first six power plants were provided directly by U.S. AID. ${ }^{101}$ By the end of 1965, eighteen such power plants were in operation (Figure 7). While this project was relatively small in scale and centered primarily on areas affected by the violence, it did promote overall development in the villages served.

The military civic action field day program (Dias de Campo) was initiated in 196 . as a means to provide various needed services, such as medical, dental, and veterinary visits to rural areas. ${ }^{102}$ All Colombian military schools, training centers, brigade headquarters, and units of battalion size or larger were required to establish a monthly civic action day program. The procedure followed was that first, a publicity campaign announced the date of the civic action day and then military forces would arrive at a village and set up a "country fair" arrangement. In addition to the medical services offered, haircuts and shoe repairs would be provided, as well as the distribution of CARE food packages. ${ }^{103}$ During 1964, the Army alone performed a significant number of services for the populace through the monthly civic action day program (Table 6). 


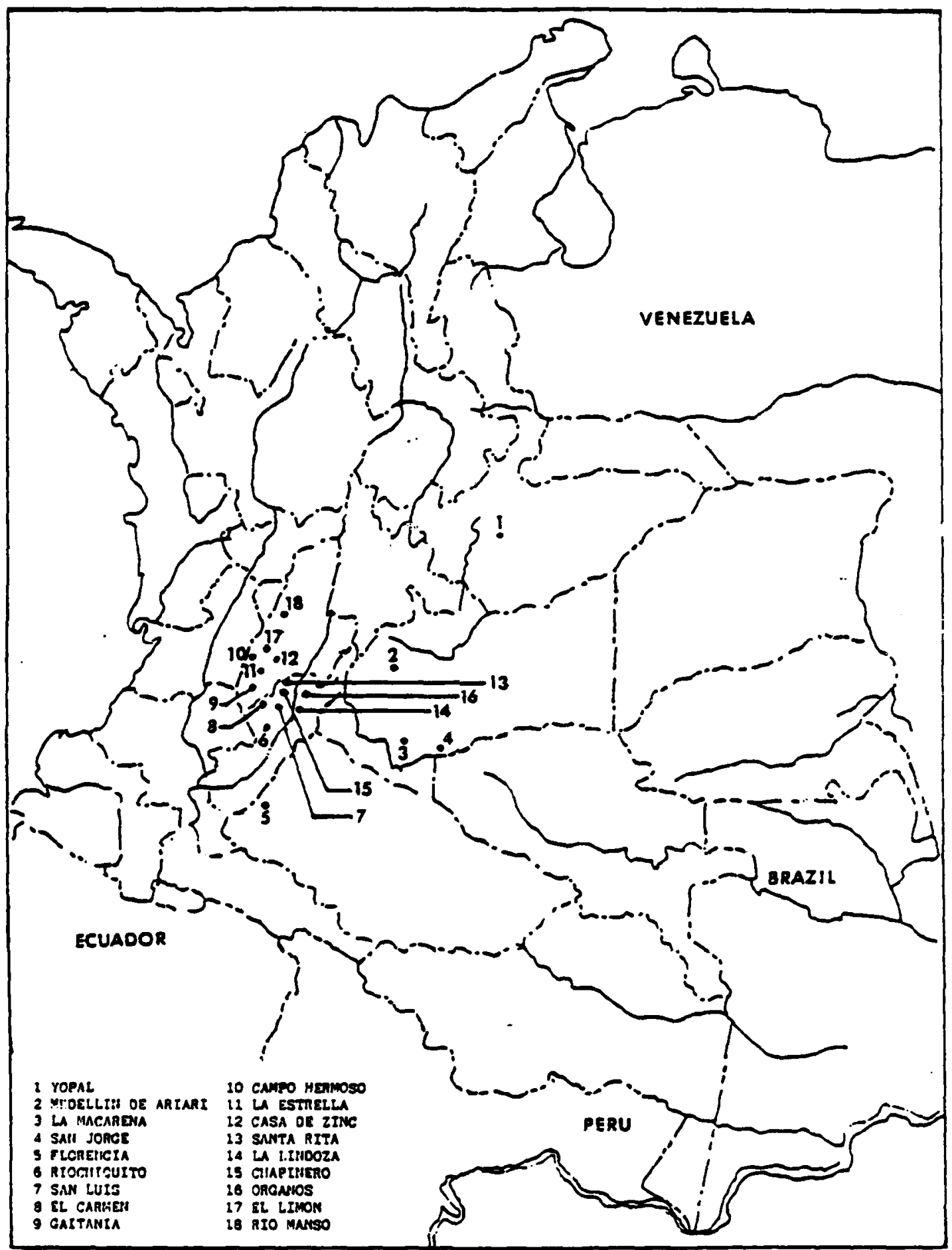

Figure 7. Military sponsored rural electrification sites (1965)

Source: Norman D. Smith, Howard K. Kaufman, and Charles D. Hindie, Effects of Military Civic Action on Attitudes: An Empirical Study in Colombia (Washington, D.C.: Center for Research in Social Systems, American University, lay 1969), p. 36. 
Table 6. Colombian Army monthly civic action field day results (1964)

\begin{tabular}{lr}
\hline \multicolumn{1}{c}{ Service } & Number Involved \\
\hline Medical Consultations & 66,700 \\
Dental Treatment & 51,400 \\
Imnunization and First Aid & 57,200 \\
Distribution of CARE Packages & 123,400 \\
Haircuts and Shoe Repair & 89,400 \\
Veterinary Services & 14,000 \\
Documentation & 7,400 \\
\hline
\end{tabular}

Source: U.S. Southern Command, Civic Action Projects Reports: I March 1964-1 January 1965 (Quarry Heights, Canal Zone: Author, 11 March 1965), p. 65.

While the Colombian military continued to support the monthly civic action field days, the program was perceived as being of low value by some U.S. Army planners. This position was supported by the Colombian military forces civic action staff section, which reported in 1965:

- . the civic action day has often had a negative effect by giving the people something they have never had before so that later they miss it and blame the authorities for lack of continuing interest. 104

However, field days were not abandoned completely as part of the Colombian civic action program. Indeed the air force and navy also supported similar civic action type days, although on a much smaller scale than the army.

As has been seen, the civic action program that developed in Colombia encompassed a variety of projects and goals. These projects also varied as to the benefits achieved and contributions made to 
national development in return for the monetary investment. Between 1962 and 1969 the United States provided Colombia $\$ 7,704,000$ in Military Assistance Program funds, and $\$ 2,111,000$ in AID funding to support civic action, while the Colombian government contributed 104 million pesos to support the same program. 106 what was achieved with these monies? Table 7 summarizes what had been done by the end of 1969 .

Table 7. Colombian civic action program accomplishments (1962-1969)

\begin{tabular}{lr}
\hline \multicolumn{1}{c}{ Program } & Quantity \\
\hline 1. Roads (Miles) & 138 \\
a. Construction & 140 \\
b. Maintenance & \\
2. Health Treatment (Number of Civilians) & $1,123,500$ \\
a. Medical & 893,000 \\
b. Dental & 160,000 \\
3. Education of Conscripts & 44 \\
4. Miscellaneous Construction & 23 \\
a. Water We11s & 26 \\
b. Health Centers & 99 \\
c. Bridges & \\
d. Schools & \\
\hline
\end{tabular}

Source: U.S. Southern Command, Civic Action Narrative Report-Colombia (Quarry Heights, Canal Zone: Author, 969), p. 3 .

A more difficult thing to measure is the extent to which civic action contributed to lasting national development and aided in reducing violence levels. These larger issues will be discussed in the following section. 


\section{Notes}

1Anthony P. Maingot, "Colombia," in The Military in Latin American Socio-Political Evolution: Four Case Studies, ed. L. N. McATister (Washington, D.C.: American Institute for Research, 1970), p. 142.

${ }^{2}$ Richard L. Maullin, Soldiers, Guerrillas, and Politics in Colombia (Lexington, Massachusetts: Lexington Books, 1973), pp. 13536.

3 James V. Coniglio, "The Nationalization of the Colombian Army: La Reforma Militar" (Master's thesis, University of Florida, Gainesville, 1970), pp. 46-47.

${ }^{4}$ Ibid., pp. 89-90.

5 Robert William Studer, "The Colombian Army: Political Aspects of Its Role" (Ph.D. dissertation, University of Southern California, Los Angeles, 1975), p. 72.

6ralph T. Tierno, Jr., ed., Army Roles, Missions, and Doctrine in Low Intensity Conflict-Pre-Conflict Case Study 2: Colombia Carlisle Barracks, Pennsylvania: Carlisle Research Office for U.S. Army Combat Developments Command Institute for Advanced Studies, 15 December 1969), pp. 229-230.

7J. Mark Ruh1, Colombia: Armed Forces and Society (Syracuse, New York: Syracuse University, 1980), p. 20.

8 Ibid.

${ }^{9}$ Maullin, Soldiers, p. 57.

${ }^{10}$ Christine S. Galbraith, "Colombian Participation in the Korean War" (Master's thesis, University of Florida, Gainesville, 1973), pp. 13-14.

11 Harold A. Hovey, United States Military Assistance: A Study of Policies and Practices (New York: Frederick A. Praeger, Publishers, 1965), p. 52 .

12 James Frederick Lacy, "Origins of the U.S. Army Advisory System: Its Latin American Experience, 1922-1941" (Ph.D. dissertation, Auburn University, Auburn, 1977), p. 154.

13 Ibid.

14U.S., Statutes at Large, vol. 44, pt. 2 (December 1925-March 1927), "Latin-American Republics," 19 May 1926. 
15 Lacy, "Army Advisory System," pp. 156-158.

16 Ibid., pp. 159-161.

17 David Bushne 11, Eduardo Santos and the Good Neighbor, 1938-1942, Latin American Monographs, Second Series, no. 8 Gainesville, Florida: University of Florida Press, 1967), pp. 8-10.

18 Lacy, "Army Advisory System," pp. 163-167.

19 Bushne11, Good Neighbor, pp. 54-55.

20 U.S. State Department, Foreign Relations of the United States-The American Republics, vol. 5 (Washington, D.C.: U.S. Government Printing Office, 1961), p. 63.

${ }^{21}$ Raymond Estep, United States Military Aid to Latin America (Maxwell Air Force Base, Alabama: Air University Documentary Research Study, 1966), p. 157.

${ }^{22}$ U.S. State Department, Foreign Relations of the United States - The American Republics, vol. 7 (Washington, D.C.: U.S. Government Printing Office, 1967), p. 804.

23U.S. State Department, The Department of State Bulletin 21 (26 September 1949): 479-480.

24 James C. Pitts, "Language Spanish, Bond Is Uniform at USARSA," Army 33 (January 1983): 25.

${ }^{25}$ Will lard F. Barber and C. Neale Ronning, Internal Security and Military Power: Counterinsurgensy and Civic Action in Latin America (Columbus, Ohio: Ohio State University Press, 1966), p. 145.

26 Ibid., p. 158.

${ }^{27}$ Normal H. Garrison, "Have Skills, Will Travel," Army Information Digest 21 (February 1965): 26-27.

28 Barber and Ronning, Civic Action in Latin America, pp. 157-159.

29 "The Spanish-Speaking Man in the Green Beret," Army Information Digest 21 (March 1966): 60.

30Maingot, "Colombia," p. 174.

31 U.S. Army Special Warfare Center, Visit to Colombia, South America, by a Team from Special Warfare Center, Fort Bragg, North Carolina (Fort Bragg, North Carolina: Author, 26 February 1962), pp. 3-4. 


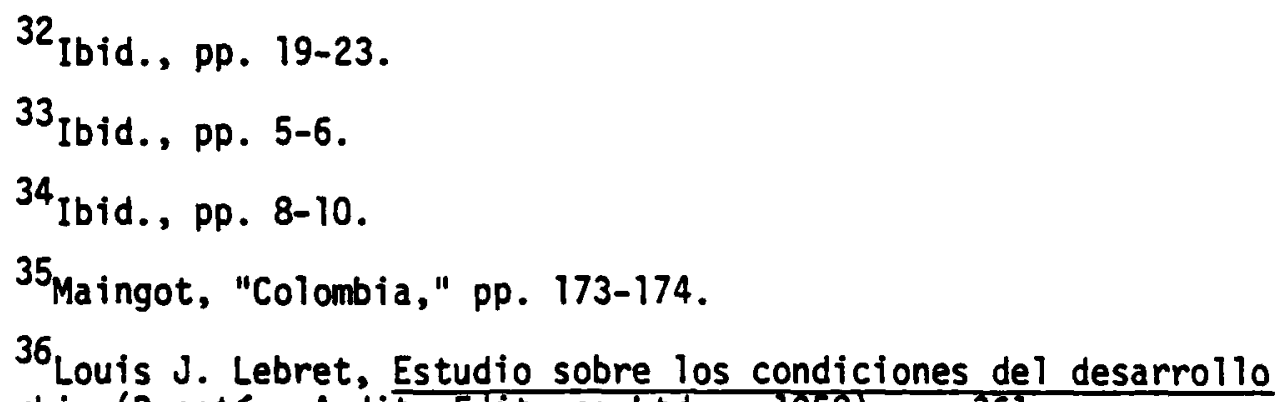
de Colombia (Bogotá: Aedita Editores Ltda., 1958), p. 361 .

37 Maingot, "Colombia," p. 174.

38 Barber and Ronning, Civic Action in Latin America, p. 192.

${ }^{39}$ John H. Doney, Jr., "A Study of United States Support of Civic Action in Colombia" (Master's thesis, University of Southern California, Los Angeles, 1966), p. 16.

${ }^{40}$ Norman D. Smith, Howerd K. Kaufman, and Charles D. Windle, Effects of Military Civic Action and Attitudes: An Empirical Study in Colombia (Washington, D.C.: Center for Research in Social Sys tems, American University, May 1969), p. 14.

${ }^{41}$ U.S. Southern Command, Civic Action Projects Report: 1 March 1964-1 January 1965 (Quarry Heights, Canal Zone: Author, 11 March 1965), p. 69 .

42 Ibid.

${ }^{43}$ U.S. Air Force Mission to Colombia, Briefing on U.S. Air Force Mission to Colombia and Colombian Air Force (Bogotá, Colombia: Author, 4 October 1962), p. 14.

${ }^{44}$ Russell W. Ramsey, "The Modern Violence in Colombia, 19461965" (Ph.D. dissertation, University of Florida, Gainesville, 1970), pp. 424-425.

45 U.S. Southern Command, Civic Action Projects Reports: I March 1964-1 January 1965, p. 69.

${ }^{46}$ Maullin, Soldiers, p. 73.

${ }^{47}$ Gonza lo Sánchez and Donny Meertens, Bandoleros, gamonales, y campesinos: El caso de la violencia en Colombia (Bogotá: ET Ancora Editores, 1983), p. 232.

48 Mauli in, Soldiers, p. 73.

${ }^{49}$ Octava Brigada, De la violencia a la paz (Manizales:

Imprenta Departamental de Caldas, 1965), p. 17. 
${ }^{50}$ Ramsey, "Violence," pp. 423-242.

${ }^{51}$ Colombia, Ministerio de Defensa Nacional, Memoria al Congreso-1968 (Bogota: Ministerio de Defensa, 1968), p. 54.

52 Doney, "United States Support of Civic Action," pp. 17-19.

${ }^{53}$ Smith, Kaufman, and Windle, Effects of Military Civic Action, pp. $18-35$.

54 Ibid., p. 18.

55 Barber and Ronning, Civic Action in Latin America, p. 194.

${ }^{56}$ Doney, "United States Support of Civic Action," p. 38.

57 U.S. Army School of the Americas, Academic Evaluation Report: Colombia (Fort Benning, Georgia: Author, 1946-1970.

58 U.S. Southern Command, Civic Action Projects Reports: 1 March 1964-1 January 1965, p. 349.

${ }^{59}$ U.S. Southern Command, Civic Action Projects Reports: July-December 1964 (Quarry Heights, Canal Zone: Author, n.d.), Enclosure 3, Section III, p. I.

60 U.S. Southern Command, Civic Action Projects Reports: 1 March 1964-1 January 1965, p. 349.

${ }^{61}$ Ibid., p. 68.

62 Doney, "United States Support of Civic Action," p. 38.

${ }^{63}$ Smith, Kaufman, and indle, Effects of Military Civic Action, p. 19.

64 Doney, "United States Support of Civic Action," p. 36.

${ }^{65}$ Smith, Kaufman, and Windle, Effects of Military Civic Action, p. 19.

66U.S. Army School of the Americas, Academic Evaluation Reports: Colombia.

${ }^{67}$ Hugh Hanning, The Peaceful Uses of Military Forces (New York: Frederick A. Praeger, Publishers, 1967), p. 78.

68 U.S. Southern Command, Civic Action Projects Reports: 1 March 1964-1 January 1965, pp. 65-66. 
69 Ibid.

70 Doney, "United States Support of Civic Action," p. 47.

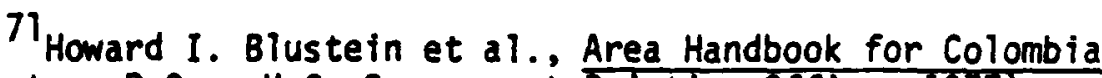

(Washington, D.C.: U.S. Government Printing Office, 1977), P. 179.

72 Hanning, Peaceful Uses, p. 77.

${ }^{73}$ Smith, Kaufman, and Windle, Effects of Military Civic Action, p. 24.

74 U.S. Southern Command, Civic Action Projects Reports: July-December 1964, p. 1.

${ }^{75}$ U.S. Army Forces Southern Command, The U.S. Army and Civic Action in Latin America (volume 3): 1 July 1963 to June 1967 (Quarry Heights, Canal Zone: Author, 1967), p. 36.

76 U.S., Congress, House, Committee on Government Operations, U.S. AID Operations in Latin America under the Alliance for Progress, Hearings before a Subcommittee of the House Cormittee on Government Operations. 90th Cong., $2 \mathrm{~d}$ Sess., 1968, pp. IIT-112.

${ }^{77}$ Smith, Kaufman, and Windle, Effects of Military Civic Action, p. 24 .

78 U.S., Congress, House, U.S. AID Operations, p. 111.

79 U.S., Congress, Senate, Committee on Foreign Relations, Survey of the Alliance for Progress: Colombia-A Case History of U.S. AID. 9lst Cong., 1st Sess., 1969, p. 91.

${ }^{80}$ Doney, "United States Support of Civic Action," p. 52.

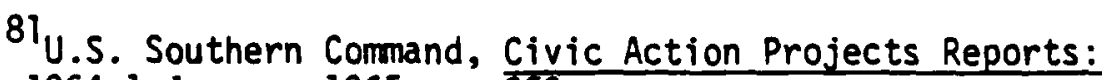
1 March 1964-1 January 1965, p. 350 .

82 Ibid.

${ }^{83}$ See Colombia, Ministerio de Defensa Nacional, Memoria al Congreso-1968 (Bogotá: Ministerio de Defensa, 1968), pp. 54, 135136, 160-161; Colombia, Ministerio de Defensa Nacional, Memoria a) Congreso-1969 (Bogotá: Ministerio de Defensa, 1969), pp. 66-67, 109,134 .

${ }^{84}$ U.S. Southern Command, Civic Action Projects Reports: 1 March 1964-1 January 1965, p. 350 . 
85 U.S. Army Forces Southern Command, The U.S. Army and Civic Action in Latin America (volume 3): 1 July 1963 to June 1967, 0. 35.

${ }^{86}$ Doney, "United States Support of Civic Action," p. 60.

87 U.S. Southern Command, Civic Action Projects Reports: 1 March 1964-1 January 1965, p. 211.

88. U.S. Army Forces Southern Command, The U.S. Army and Civic Action in Latin America (volume 3): 1 July 1963 to June 1967, p. 37.

${ }^{89}$ Hanning, Peaceful Uses, p. 82.

90 U.S. Southern Command, Civic Action Projects Reports: 1 March 1964-1 January 1965, p. 70.

91 Barber and Ronning, Civic Action in Latin America, p. 193.

${ }^{92}$ Smith, Kaufman, and Windle, Effects of Military Civic Action, p. 27.

93 Ibid.

94U.S. Southern Command, Civic Action Projects Reports: I March 1964-i January 1965, p. 109.

${ }^{95}$ Doney, "United States Support of Civic Action," p. 65.

${ }^{96}$ Smith, Kaufman, and Windle, Effects of Military Civic Action, p. 27.

97Doney, "United States Support of Civic Action," pp. 68-69.

${ }^{98}$ Smith, Kaufman, and Windle, Effects of Military Civic Action, p. 31 .

99 Doney, "United States Support of Civic Action," pp. 71-72.

${ }^{100}$ Smith, Kaufman, and Windle, Effects of Military Civic Action, p. 31 .

${ }^{101}$ U.S. Southern Command, Civic Action Projects Reports: 1 March 1964-1 January 1965, p. 66 .

102 Enrique Lequizamo Barrera, "Acción civica y social de las Fuerzas Armadas," Revista de las Fuerzas Armadas 5 (Agosto 1962): 621-626.

103 Hanning, Peaceful Uses, p. 80. 
${ }^{104}$ Smith, Kaufman, and Windle, Effects of Military Civic Action, p. 31 .

105 U.S. Southern Command, Civic Action Narrative Report-Colombia (Quarry Heights, Canal Zone: Author, 1969), p. 2. 


\section{THE CASE FOR \\ MILITARY CIVIC ACTION}

Despite.the considerable number of nations in Latin America and throughout the world that conducted civic action programs during the 1960s, no magical formula for the evaluation of the success or failure of a program was ever constructed. On the whole, subjective judgments were made, either by the proponents of the civic action concept or the actual executors of their respective programs. However, while no specific formula was ever arrived at, researchers have agreed on the need for detailed information before any conclusions as to effectiveness can be offered.

Prof. Lyle N. MCAlister has suggested a set of questions, with respect to Latin American militaries, that bear directly on the evaluation of civic action:

How many functional literates have the Latin American armed forces (or any one of them) actually produced? How many technicians have they in fact contributed to the national pool, and what have these men actually done with their skilis? How many manufactured goods have in fact been produced as a consequence of the military's interest in industrialization? Even more fundamental, how do the contributions of the military in these areas compare qualitatively with the work of civilian agencies? Or if the armed forces had not done these things would they have been done at all? . . . If proportionate amounts of military budgets had been transferred to Departments of Education, Industry, and Cormerce and Agriculture, would the accomplishments have been greater or less?

Questions such as these call for detailed information which is not always readily available. In the Colombian case, however, statistics 
of one sort or another, such as road mileage construction, number of persons receiving health care, number of schools built, and so on, are available for review. These statistics alone (as presented in the previous sections) cannot provide a definitive answer, but in reviewing the results of the specific civic action projects which the Colombian military sponsored or co-sponsored in the early 1960 s it appears that contributions were made to further national development as well as helping to cope with the violence.

Projects such as the National Territory Radio Network as well as the operation of SATENA aided in tying the isolated and remote portions of the nation into the national government. Additionaliy, the armed forces literacy program which was specifically designed to aid in the reduction of illiteracy among military recruits did in fact accomplish its goal. While the road construction and maintenance program was not an unqualified success on the national level, the roads constructed in the violence-affected areas in all likelihood might never have been constructed if the military had not done so. Also, the schools constructed by the military in violence-affected and remote areas, while few in number when compared to the total national education program, did make it possible for children in these remote areas to obtain an exposure to formal education that otherwise might not have been possible. The establishment of health centers as well as air and water mobile dispensaries improved the availability and quality of health care for the populace throughout the areas in which they operated. The youth camp program, while not producing as immediate resuits as the rural 
school construction projects, did attempt to influence a child's development and break the pattern of endemic violence which had evolved in some areas.

How successful were these as well as the other civic action projects in aiding to reduce the levels of violence in the nation? This is an even more complex question, but one of particular importance for Colombia in view of circumstances that led to the introduction of military civic action programs. There are statistical indicators of changing levels of violence, but obviously. the levels are affected by many different factors. The mere establishment of the National Front coalition government was followed by a significant reduction of deaths between 1958 and 1959 (Table 8).

Table 8. Deaths attributed to la violencia $(1958-1965)$

\begin{tabular}{lrrrrrrrrr}
\hline \hline & \multicolumn{10}{c}{ Years } \\
\cline { 2 - 9 } & 1958 & 1959 & 1960 & 1961 & 1962 & 1963 & 1964 & 1965 \\
\hline Soldiers & 69 & 18 & 88 & 32 & 102 & 66 & 46 & 63 \\
Civilians & 4,900 & 3,090 & 2,286 & 2,570 & 2,419 & 1,436 & 730 & 655 \\
Guerrillas & 373 & 132 & $\frac{247}{236}$ & $-\frac{388}{236}$ & -482 & 352 & 379 \\
TOTAL & 5,342 & 3,240 & 2,621 & 2,838 & 2,909 & 1,984 & 1,128 & 1,097
\end{tabular}

Source: Joan E. Garcés, "Structural Obstacles to the Development of Revolutionary Political Forces in Colombia," Government and Opposition 6 (Summer 1971): 318. 
On the military side, it is noteworthy that the establishment of a formal civic action program in 1963 coincided with another sizeable drop in the number of deaths due to the violence. Of course, it must first be remembered that in accordance with Plan Lazo, beginning in July 1962, a more concerted and sophisticated effort was launched to deal with the rural guerrilla bands. Nevertheless, the civic action program was an integral part of the military's overall effort to help end the violence, and though it is impossible to distinguish the exact contribution made by any one approach in achieving the end result, the downward trend in the number of deaths attributed to la violencia after 1962 is clear. The death rate continued to decline, as during 1966 the toll was approximately 900, and by the end of 1967 it had fallen to $480 .^{2}$ Another indicator is the decline in number of active cuadrillas. In 1962, there were seventy-five active cuadrillas with a total strength of about 1,500 men, while in 1964 the number of cuadrillas had fallen to thirty-three with some 800 men. ${ }^{3}$ An important factor in the success or failure of civic action in particular is the populace's attitudes toward and perceptions of the program. According to the Commander in Chief, U.S. Army Forces Southern Command, in a report to Congress in 1965

had been pronounced reduction of disturbances and hostilities.
action prople in Colombia who had benefited from the civic
benefactors and have cooperated with the armed forces by
providing them with information regarding bandit activities
and locations. The cooperation of the populace with the
military has increased in the last two years from an
estimated 15 to 85 percent in civic action project regions. 4


Although this view came from the U.S. Commander of the forces involved in supporting civic action programs throughout Latin America and may have reflected a degree of vested interest in showing the success of the concept, its essential conclusions were more than borne out by the results from another study conducted between July 1965 and March 1966 by the Center for Research in Social Systems (CRESS) of the American University, under contract with the U.S. Department of Defense.

This civic action study (codename: Simpatico) was launched after an agreement was reached between the U.S. and Colombian governments to obtain empirical information on how military civic action influences the attitudes of people toward their army and their government. 5 The findings of the study are based on the results of interviews with 1,229 persons from 105 villages in Colombia. The majority of sites chosen were located along the Cauca and Magdalena Rivers and adjoining highlands. Approximately half the locations had been exposed to some form of civic action programs while the rest had not been. The major findings of this study were

1. The great majority of villagers repeatedly expressed favorable attitudes toward military civic action. Few villagers ( 2 percent) expressed any negative feeling. The principal views expressed were that military civic action is beneficial, and that the program should be expanded.

2. Villagers associated both the army and the government with military civic action.

3. Where military civic action projects occurred, more favorable attitudes were expressed toward soldiers and the government than in areas where there were no military civic action projects.

4. Where military civic action projects occurred, there were relatively more villagers expressing attitudes of 
self-reliance and a preference for scientific-technical rather than humanistic occupations. In departments where great violence had occurred, villagers were found to have a more favorable view toward their village.

6. Different types of military civic action programs did not produce large and reliable differences in attitudes. 6

The Colombian experience with military civic action in the 1960 s has thus shown that if the military is employed in projects which can be adequately supported by the forces involved, there can be many benefits for all concerned. Quite apart from the reduction of political violence levels where such conditions exist, the local populace may have their conditions of life improved, while the military can be used to promote socioeconomic development and not simply for "dress parades." The national government through civic action programs, as well as the improvement of other services, can help tie the more remote, rural areas into the nation's mainstream. Clearly, the militaries of the world are not about to be done away with. Such being the case, there is much to be said for their being used in those capacities which, while not degrading their primary mission of national defense, can help further national development. 
Notes

'Edward Bernhard Glick, Peaceful Conflict: The Non-Military Use of the Military (Harrisburg, Pennsylvania: Stackpole Books, 1967), pp. 176-177.

${ }^{2}$ Richard L. Maullin, Soldiers, Guerrillas, and Politics in Colombia (Lexington, Massachusetts: Lexington Books, 1973), p. 77.

3 James M. Daniel, Rural Violence in Colombia since 1946

(Washington, D.C.: Special Operations Research Office, American University, May 1965), pp. 129-130.

${ }^{4}$ Norman D. Smith, Howard K. Kaufman, and Charles D. Windle, Effects of Military Civic Action on Attitudes: An Empirical Study (Washington, D.C.: Center for Research in Social Systems, American University, May 1969), p. 17.

5 Ibid., p. iii.

${ }^{6}$ Ibid., p. vii. 


\section{BIBLIOGRAPHY}

Anderson, Charles W.; von der Mehden, Fred R.; and Young, Crawford. Issues of Political Development. Englewood Cliffs, New Jersey: Prentice-Hail, Inc., 1967.

Arciniegas, German. The State of Latin America. New York: Alfred A. Knopf, 1952.

Auletta, Anthony J. "Ten-Nation Progress Report." Army 13 (July 1963): 53-59.

Ayerbe Chaux, Gerardo. "La rebelión en Colombia." Revista de las Fuerzas Armadas 10 (Noviembre-Diciembre 1964): 253-254.

Bailey, Jean. "Armies Can Be Builders." Army Information Digest 20 (February 1965): 16-19.

Bailey, Jean. "Mapping in Latin America." Army Information Digest 20 (February 1965): 20-25.

Bailey, Norman A. Latin America: Politics, Economics, and Hemispheric Security. New York: Frederick A. Praeger, Publisher, 1965.

Bailey, Norman A. "La Violencia in Colambia." Journal of InterAmerican Studies 9 (October 1967): 561-575.

Baines, John M. "U.S. Military Assistance to Latin America." Journal of Inter-American Studies and World Affairs 14 (November 1972): 469-487.

Barber, Williard F. "The Foreign Assistance Program." Military Review 45 (March 1965): 45-55.

Barber, Williard F., and Ronning, C. Neale. Internal Security and Military Power: Counterinsurgency and Civic Action in Latin America. Columbus, Ohio: Ohio State University Press, 1966.

Barrera Rueda, Oscar Leone1. "Acción sicologica en apoyo de operaciones contra guerrillas." Revista de las Fuerzas Armadas 10 (Enero y Febrero 1965): 475-482.

Bashore, Boyd T. "Dual Strategy for Limited War." Military Review 40 (May 1960): 46-62. 
Bauer, Charles J. "USARCARIB's Biggest Little School." Army Information Digest 17 (October 1962): 24-28.

Beltran, Hernando. "Las Fuerzas Armadas como elemento vital en el desarrollo de los pueblos." Revista de las Fuerzas Armadas 25 (1973): 275-285.

Bentz, Harold F., Jr. "Psychological Warfare and Civic Action." Army 13 (July 1963): 62-65.

Blaufarb, Douglas S. The Counterinsurgency Era: U.S. Doctrine and Performance. New York: The Free Press, A Division of Macmiltan Publishing Company, Inc., 1977.

Blustein, Howard I.; Edwards, J. David; Johnson, Kathryn Therese; McMorris, David S.; and Rudolph, James D. Area Handbook for Colombia. Washington, D.C.: U.S. Government Printing Office, 1977.

Bobrow, Davis B. "The Civic Role of the Military: Some Critical Hypotheses." In Components of Defense Policy, pp. 272-289. Edited by Davis B. Bobrow. Chicago: Rand McNally \& Company, 1965.

Booth, John A. "Rural Violence in Colombia: 1948-1963." The Western Political Quarterly 27 (December 1974): $65 \overline{7-679}$.

Brown, W. A., and Opie, R. American Foreign Assistance. Washington, D.C.: The Brookings Institution, 1953.

Burke, Robert L. "Military Civic Action." Military Review 44 (October 1964): 62-71.

Bushne11, David. "Andean South America to Mid-Century: Consolidation of a New Order." Gainesville, Florida, n.d. (Xeroxed.)

Bushnel1, David. "What Has Happened to Democracy in Colombia?" Current History 24 (January 1953): 38-43.

Bushne11, David. Eduardo Santos and the Good Neighbor, 1938-1942. Latin American Monographs, Second Series, no. 8. Gainesville, Florida: University of Florida Press, 1967.

Canal Ramírez, Gonzalo. "Misión civil de las Fuerzas Armadas." Revista de las Fuerzas Armadas 1 (Abril 1960): 139-143.

Canal Ramírez, Gonzalo. "Fuerzas militares y orden público." Revista de las Fuerzas Armadas 2 (Octubre 1960): 163-170. 
Child, John. "Latin America: Military-Strategic Concepts." Air University Review 27 (September-October 1976): 27-42.

Child, John. "From 'Color' to 'Rainbow': U.S. Strategic Planning for Latin America, 1919-1945." Journal of Inter-American Studies and World Affairs 21 (May 1979): 233-259.

Clark, Richard R. "U.S. Military Assistance in Latin America." Army Digest 21 (September 1966): 18=19.

Cloud, Leon B. "The Role of Military Forces in Civic Action in Developing Nations." Master's thes is, Air University, Maxwell Air Force Base, Alabama, 1971.

Coffin, Frank M. Witness for AID. Boston: Houghton Mifflin Company, 1964.

Colombia, Ministerio de Defensa Nacional. Memoria al Congreso-1968. Bogotá: Ministerio de Defensa, 1968.

Colombia, Ministerio de Defensa Nacional. Memoria al Congreso-1969. Bogotá: Ministerio de Defensa, $196 \overline{9}$

Coniglio, James V. "The Nationalization of the Colombian Army: La Reforma Militar." Master's thesis, University of Florida, Gainesville, 1970.

Corbett, Charles D. "Toward a U.S. Defense Policy: Latin America." Military Review 55 (June 1975): 11-18.

Danie1, James M. Rural Violence in Colombia since 1946. Washington, D.C.: Special Operations Research Office, American University, May 1965.

Davis, Harold Eugene; Finan, John J.; and Peck, F. Taylor. Latin American Diplomatic History. Baton Rouge, Louisiana: Louisiana State University Press, 1977.

Diaz Valderrama, Efrain. "iSe justifica la acción cfvica?" Revista de las Fuerzas Armadas 10 (Enero y Febrero 1965): $48 \overline{3-490}$.

Dix, Robert H. Colombia: The Political Dimensions of Change. New Haven, Connecticut: Yale University Press, 1967.

Doney, John H., Jr. "A Study of United States Support of Civic Action in Colombia." Master's thesis, University of Southern California, Los Angeles, 1966. 
Downen, R. E. "Communist Attempt to Convert Colombian Rural Violence into Insurgency during 1948-1966: Study of a Failure." Master's thesis, Command and General Staff College, Fort Leavenworth, Kansas, 1969.

Duggan, Lawrence. The Americas: The Search for Hemispheric Security. New York: Henry Hold and Company, 1949.

Echeverri U., Alvaro. El poder y los militares: Un anallis is de los ejércitos del continente y Colombia. Bogota: Editorial Suramerica, 1978.

Edel, Matthew David. "The Colombian Community Action Program: An Economic Evaluation." Ph.D. dissertation, Yale University, New Haven, 1968.

Estep, Raymond. United States Military Aid to Latin America. Maxwell Air Force Base, Alabama: Air University Documentary Research Study, 1966.

Fals Borda, Orlando. Subversion and Social Change in Colombia. New York: Columbia University Press, 1969.

Farer, Tom J., ed. The Future of the Inter-American System. New York: Praeger Publishers, 1979.

Fitch, John Samuel. "The Political Impact of U.S. Military Aid to Latin America: Institutional and Individual Effects." Armed Forces and Society 5 (Spring 1979): 360-386.

Fluharty, Vernon Lee. Dance of the Millions: Military Rule and the Social Revolution in Colombia, 1930-1956. Pittsburgh, Pennsylvania: University of Pittsburgh Press, 1957.

Francis, Michael J. "Military Aid to Latin America in the U.S. Congress." Journal of Inter-American Studies 6 (July 1964): $389-404$

Furniss, Edgar S. Counterinsrugency: Some Problems and Implications. New York: The Council on Religion and International Affairs, 1969.

Gailer, Frank L., Jr. "Air Force Missions in Latin America." Air University Quarterly Review 13 (Fall 1961): 45-58.

Galbraith, Christine S. "Colombian Participation in the Korean War." Master's thesis, University of Florida, Gainesville, 1973.

Galbraith, W. O. Colombia: A General Survey. 2d ed. New York: Oxford University Press, 1966. 
Garces, Joan E. "Structural Obstacles to the Development of Revolutionary Political Forces in Colombia." Government and Opposition 6 (Summer 1971): 303-332.

Garrison, Norma H. "Have Skills, Will Travel." Anmy Information Digest 21 (February 1965): 26-30.

Gibson, William Marion. The Constitutions of Colombia. Durham, North Carolina: Duke University Press, 1948.

Glick, Edward Bernhard. "The Nonmilitary Use of the Latin American Military." In Latin America: Politics, Economics, and Hemispheric Security, pp. 179-191. Edited by Norman A. Bailey. New York: Frederick A. Praeger, Inc., 1965.

Glick, Edward Bernhard. "Conflict, Civic Action, and Counterinsurgency." Orbis 10 (Fal1 1966): 899-910.

Glick, Edward Bernhard. "Military Civic Action: Thorny Art of the Peace Keepers." Army 17 (September 1967): 67-70.

Glick, Edward Bernhard. Peaceful Conflict: The Non-Military Use of the Military. Harrisburg, Pennsylvania: Stackpole Books, T967.

Gonzalez, Heliodoro. "The Alliance for Progress-The First Year: Political." Inter-American Economic Affairs 16 (Summer 1962): 23-47.

Gonzalez, Heliodoro. "The Failure of the Alliance for Progress in Colombia." Inter-American Economic Affairs 23 (Summer 1969): 87-96.

González, Heliodoro. "U.S. Arms Transfer Policy in Latin America: Failure of a Policy." Inter-American Economic Affairs 32

(Autumn 1978): 6, 7-85.

Gott, Richard. Guerrilla Movements in Latin America. New York: Doubleday \& Company, Inc., 1972.

Guntharp, Walter A., and Oliver, Covey T. "The Concept of Hemispheric Defense." Current History 56 (June 1969): 355-361, $366,367$.

Guzmán Campos, German; Fals Borda, Orlando; and Umaña Luna, Eduardo. La violencia en Colombia: Estudio de un proceso social.

Haahr, James C. "Military Assistance to Latin America." Military Review 49 (May 1969): 12-21. 
Hanning, Hugh. The Peaceful Uses of Military Forces. New York: Frederick A. Praeger, Publishers, 1967.

Hanson, Simon G. "Notes on the Alliance for Progress." InterAmerican Economic Affairs 17 (Surmer 1963): 85-96.

Hanson, Simon G. "The Alliance for Progress: The Second Year." Inter-American Economic Affairs 17 (Winter 1963): 3-104.

Hanson, Simon G. "The Alliance for Progress: Thie Third Year." Inter-American Economic Affairs 18 (Spring 1965): 3-102.

Harrison, Stanley L. "Congress and Foreign Military Sales." Military Review 51 (October 1971): 79-87.

Heare, Gertrude E. Trends in Latin American Military Expenditures, 1940-1970. Washington, D.C.: U.S. Government Printing Office, 1971.

Helguera, J. León. "The Changing Role of the Military in Colombia." Journal of Inter-American Studies 3 (July 1961): 351-358.

Henderson, James David. "Origins of the Violencia in Colombia." Ph.D. dissertation, Texas Christian University, Fort Worth, 1972.

Heymont, Irving. "U.S. Military Assistance Programs." Military Review 48 (January 1968): 89-95.

Hinson, Billy Glen. "Plans of the United States for Postwar Military Assistance to Latin America, 1945-1951." Ph.D. dissertation, University of Mississippi, Oxford, 1977.

Hobsbawm, E. J. "The Anatomy of Violence." New Society (11 Apri] 1983): $16-18$.

Hobsbawm, E. J. "The Revolutionary Situation in Colombia." The World Today 19 (June 1963): 248-258.

Hovey, Harold A. United States Military Assistance: A Study of Policies and Practices. New York: Frederick A. Praeger, Publishers, 1965.

Hughes, David R. "The Myth of Military Coups and Military Assistance." Military Review 47 (December 1967): 3-10.

Huntington, Samuel $P$. The Soldier and the State: The Theory and Politics of Civil-Military Relations. Cambridge, Massachusetts: The Belknap Press of Harvard University Press, 1959. 
Icenhour, James Otis. "The Military in Colombian Politics." Ph.D. dissertation, George Washington University, Washington, D.C., 1976.

Jiménez Mendoza, Cayo Eduardo. "Autodefensa." Revista de las Fuerzas Armadas 12 (Septiembre-0ctubre 1966): 177-184.

Johnson, John J. The Military and Society in Latin America. Stanford, California: Stanford University Press, 1964.

Johnson, John J., ed. The Role of the Military in Underdeveloped Countries. Princeton, New Jersey: Princeton University Press, 1962.

Kantor, Harry. Patterns of Politics and Political Systems in Latin America. Chicago: Rand McNally \& Company, 1969.

Kaplan, Stephen S. "U.S. Arms Transfer to Latin America, 1945-1974." International Studies Quarterly 19 (December 1975): 399-431.

Lacy, James Frederick. "Origins of the U.S. Army Advisory System: Its Latin American Experience, 1922-1941." Ph.D. dissertation, Auburn University, Auburn, 1977.

Langley, Lester D. "Military Commitments in Latin America: 19601968." Current History 56 (June 1969): 346-351, 368.

Lansdale, Edward G. "Civic Action Helps Counter the Guerrilla Threat." Army Information Digest 17 (June 1962): 50-53.

Leal Buitrago, Francisco. "Politica e intervención militar en Colombia." Revista Medicana de Sociologica 32 (Mayo-Junio 1970): $491-538$.

Lebret, Louis J. Estudio sobre las condiciones del desarollo de Colombia. Bogota: Aedita Editores Ltda., 1958.

Le Grand, Catherine C. "Perspectives for the Historical Study of Rural Politics and the Colombian Case: An Overview." Latin American Research Review 13 (1977): 7-36.

Leguizamo Barrera, Enrique. "Acción civica y social de fuerzas militares." Revista de las Fuerzas Armadas 5 (Agosto 1962): 621-626.

Lieuwen, Edwin. Arms and Politics in Latin America. New York: Frederick A. Praeger, 1961. 
Lieuwen, Edwin. "Neo-Militarism in Latin America: The Kennedy Administration's Inadequate Response." Inter-American Economic Affairs 16 (Spring 1963): 11-20.

Lieuwen, Edwin. U.S. Policy in Latin America: A Short History. New York: Frederick Praeger, Publishers, 1965.

Lieuwen, Edwin. The United States and the Challenge to Security in Latin America. Columbus, Ohio: Ohio State University Press, 1966.

Lindsey, Franklin A. "Unconventional Warfare." Military Review 42 (June 1962): 53-62.

Livingston, Hoyt R., and Watson, Francis M. "Civic Action Purpose and Pitfalls." Military Review 47 (December 1967): 21-25.

Maingot, Anthony P. "Colombia: Civil-Military Relations in a Political Culture of Conflict." Ph.D. dissertation, University of Florida, Gainesville, 1967.

Maingot, Anthony P. "Colombia." In The Military in Latin American Socio-Political Evolution: Four Case Studies, pp. 127-195. Edited by L. N. McAlister. Washington, D.C.: American Institute for Research, 1970.

Markarian, Ronald H. "Military Civic Action: Building Nations in Latin America." Master's thesis, Air University, Maxwell Air Force Base, Alabama, 1965.

Martinez Codo, Enrique. "The Military Problems in Latin America." Military Review 44 (August 1964): 11-19.

Martz, John D. Colombia: A Contemporary Political Survey. Chapel Hill, North Carolina: The University of North Carolina Press, 1962.

Martz, John D. "Political Parties in Colombia and Venezuela: Contrasts in Substance and Style." Western Political Quarterly 18 (June 1965): 318-333.

Massoglia, Martin M.; McMullan, Philip S.; and Dillard, Clarence M. Military Civic Action-Evaluation of Military Techniques. Research Park, North Carolina: U.S. Army, July T97.

Maullin, Richard L. "The Private War of a Guerrilla: Violence, Banditry and Politics on the Colombian Frontier." Trans-Action 7 (March 1970): 45-54. 
Maullin, Ricahrd L. Soldiers, Guerrillas, and Politics in Colombia. Lexington, Massachusetts: Lexington Books, 1973.

McAlister, Lyle N. "The Military." In Continuity and Change in Latin America, pp. 136-160. Edited by John J. Johnson. Stanford, California: Stanford University Press, 1964.

MCAlister, Lyle N. "Recent Research and Writings on the Role of the Military in Latin America." Latin American Research Review 2 (Fall 1966): 5-36.

Mecham, J. Lloyd. The United States and Inter-American Security, 1889-1960. Austin, Texas: University of Texas Press, 1961.

Mercado Jarrin, Edgardo. "Insurgency in Latin America: Its Impact on Political and Military Strategy." Military Review 49 (March 1969): $10-20$.

Meyer, Charles A. "United States Military Activities in Latin America." Inter-American Economic Affairs 23 (Autumn 1969): 89-94.

Milikan, M. F., and Rostow, W. W. "Foreign Aid: Next Phase." Foreign Affairs 36 (Apri1 1958): 418-436.

Morton, Glenn A. "The Inter-American Air Forces Academy." Air University Review 18 (November-December 1966): 13-20.

Needler, Martin C. Latin American Politics in Perspective. Princeton, New Jersey: D. Van Nostrand Company, Inc., 1983.

Needler, Martin C. "The Latin America Military: Predatory Reactionaries or Modernizing Patriots?" Journal of InterAmerican Studies 9 (April 1969): 237-244.

Nordlinger, Eric. A. "Soldiers in Mufti: The Impact of Military Rule upon Economic and Social Changes in the Non-Western States." The American Political Science Review 64 (December 1970): 1137-1148.

Nunn, Frederick M. Yesterday's Soldiers: European Military Professionalism in South America, 1890-1940. Lincoln, Nebraska: University of Nebraska Press, 1983.

Nusbaum, Keith C. "Bandidos." Military Review 43 (July 1963): 20-25.

Octava Brigada. De la violencia a la paz. Manizales: Imprenta Departamental de Caldas, 1965. 
O'Meara, Andrew P. "Opportunities to the South of Us." Army 13 (November 1962): 41-43.

O'Nei1, Robert. "Military Civic Action: A Unique Approach in Military Assistance." Maser's thesis, Air University, Maxwell Air Force Base, Alabama, 1976.

Oquist, Paul H. Violencia, conflicto, y polftica en Colombia. Bogota: Instituto de Estudios Colombianos, 1978.

Pach, Chester Joseph, Jr. "Arming the Free World: The Origins of the United States Military Assistance Program, 1945-1949." Ph.D. dissertation, Northwestern University, Evanston, Illinois, 1981.

Pancake, Frank R. "Why Military Assistance for Latin America." Air University Review 18 (November-December 1966): 2-12.

Pancake, Frank R. "Military Assistance as an Element of U.S. Foreign Policy in Latin America, 1950-1968." Ph.D. dissertation, University of Virginia, Charlottesville, 1969.

Payne, James L. "The Oligarchy Muddle." World Politics 20 (April 1968): $439-453$.

Payne, James L. Patterns of Conflict in Colombia. New Haven, Connecticut: Yale University Press, 1968.

Pitts, James C. "Language Spanish, Bond Is Uniform at USARSA," Army 33 (January 1983): 23-28.

Pollock, John C. "Violence, Politics, and Elite Performance: The Political Sociology of La Violencia in Colombia." Studies in Comparative International Development 10 (Summer 1975): 22-50.

Poppino, Rollie E. "The Early Cold War." Current History 56 (June 1969): 340-345, 369-370.

Powell, John Duncan. "Military Assistance and Militarism in Latin America." Western Political Quarterly 18 (June 1965): 382-392.

Puckett, Ralph, Jr., and Galvin, John R. "Lancero." Infantry (July-September 1959): 21-23.

Rabe, Stephen G. "Inter-American Military Cooperation, 1944-1951." World Affairs 137 (Fall 1974): 132-149.

Ramsey, Russell W. "Colombian Infantry Faces Insurgency!!" Infantry 54 (November-December 1964): 4-8. 
Ransey, Russell W. "The Modern Violence in Colombia, 1946-1965." Ph.D. dissertation, University of Florida, Gainesville, 1970.

Ramsey, Russell W. Survey and Bibliography of La Violencia in Colombia. Gainseville, Florida: University of Florida Libraries, 1974.

Ramsey, Russell W. Civil-Military Relations in Colombia, 1946-1965. N.p.: Regent Publishing Company, Inc., 1978.

Randa 11, Stephen J. The Diplomacy of Modernization: ColombianAmerican Relations, 1920-1940. Toronto: University of Toronto Press, 1977.

Rippy, J. Fred. "Latin America and U.S. Funds for Foreign Aid, Fiscal Year 1963." Inter-American Economic Affairs 16 (Spring 1963): 73-82.

Robertson, Frank H. "Military Assistance Training Program." Air University Review 19 (September-October 1969): 27-36.

Rodriguez Lievano, Guillermo. "La pacificacion." Revista de las Fuerzas Armadas 15 (Mayo-Junio 1967): 213-रा7.

Rosson, William B. "Accent on Cold War Capabilities." Army Information Digest 17 (May 1962): 2-9.

Rosson, William B. "The U.S. Army in Special Warfare." Army 13 (November 1962): 59-62.

Rosson, William B. "Understanding Civic Action." Army 13 (July 1963): $46-47$.

Roush, Maurice D. "Master Plans for Nationbuilding." Military Review 49 (February 1969): 77-85.

Rueda Vargas, Tomás. El Ejército Nacional. Bogotá: Imprenta y Litograffa de Las Fuerzas Militares, 1969.

Ruhl, J. Mark. Colombia: Armed Forces and Society. Syracuse, New York: Syracuse University, 1980.

Ruhl, J. Mark. "The Military." In Politics of Compromise: Coalition Government in Colombia, pp. 181-206. Edited by R. Albert Berry, Ronald G. Hellman, and Mauricio Solaun. New Brunswick, New Jersey: Transaction Books, 1980.

Ruh1, J. Mark. "Civil-Military Relations in Colombia: A Societal Explanation." Journal of Inter-American Studies and World Affairs 23 (May 1981): 123-146. 
Ruiz Novoa, Alberto. Enseñanzas militares de la campaña de Corea. Bogota: Antares, 1956.

Ruiz Novoa, Alberto. "Polftica y doctrina de guerra." Revista de las Fuerzas Armadas 1 (Junio 1960): 231-238.

Ruiz Novoa, Alberto. "La acción cívica en los movimientos insurreccionales." Revista de las Fuerzas Armadas 7 (JulioAgos to 1963): $491-495$.

Ruiz Novoa, Alberto. El gran desafio. Bogotá: Ediciones Tercer Mundo, 1965.

Russe11, Robert R. "Reduced Military Assistance to Latin America: The Impact on U.S.-Colombia Relations." Master's thesis, Air University, Maxwell Air Force Base, Alabama, 1970.

Sánchez, Gonzalo, and Meertens, Donny. Bandoleros, gamonales, y campesions: El caso de la violencia en Colombia. Bogotá: El Ancora Editores, 1983.

Sandos, James A. "U.S. Military Policy toward Latin America." World Affairs 135 (Spring 1973): 293-308.

Santacruz, Dario. "¿Estamos en guerra?" Revista de las Fuerzas Armadas 10 (Marzo-Abril 1965): 3-б.

Schmitter, Philippe C., ed. Military Rule in Latin America: Function, Conseguences, and Perspectives. London: Sage Publications, 1973.

Schober, John K. "Colombia: Violence and Electoral Participation, 1937-1968." Master's thesis, University of Florida, Gainesville, 1971 .

Schoultz, Lars. Human Rights and United States Policy toward Latin America. Princeton, New Jersey: Princeton University Press, 1981.

Slover, Robert H. "Action through Civic Action." Army Information Digest 17 (October 1962): 7-11.

Slover, Robert $H$. "This Is Military Civic Action." Army 13 (JuTy 1963): 48-52.

Smith, Margaret Chase, Sen. "On the Alliance, the Vitalizing of Forces for Evolutionary Change, and the Military." Inter-American Economic Affairs 16 (Summer 1962): 89-95. 
Smith, Norman D.; Kaufman, Howard K.; and Windle, Charles D. Effects of Military Civic Action on Attitudes: An Empirical Study in Colombia. Washington, D.C.: Center for Research in Social Systems, American University, May 1969.

"The Spanish-Speaking Man in the Green Beret." Army Information Digest 21 (March 1966): 60.

Steel, Charles Lowndes. "Colombian Experience in Korea and Perceived Impact on La Violencia, 1953-1965." "Master's thesis, University of Florida, Gainesville, 1978.

Studer, Robert William. "The Colombian Army: Political Aspects of Its Role." Ph.D. dissertation, University of Southern California, Los Angeles, 1975.

Taylor, Philip B., Jr. "Hemispheric Defense in World War. II." Current History 56 (June 1969): 333-339.

Tierno, Ralph T., Jr., ed. Army Roles, Missions, and Doctrine in Low Intensity Conflict-Pre-Conflict Case Study 2: Colombia. Carlisle Barracks, Pennsylvania: Carlisle Research Office for U.S. Army Combat Developments Command Institute of Advanced Studies, 15 December 1969.

Torres Restrepo, Camilo. "Social Change and Rural Violence in Colombia." In Masses and Mobilization, pp. 503-546. Edited by Irving Louis Horowitz. New York: Oxford Press, 1970.

U.S. Statutes at Large, vol. 44, pt. 2 (December 1925-March 1927). "Latin-American Republics," 19 May 1926.

U.S. Air Force Mission to Colombia. Briefing on U.S. Air Force Mission to Colombian Air Force. Bogotá, Colombia: Author, 4 October 1962 .

U.S. Army Forces Southern Command. The U.S. Army and Civic Action in Latin America (volume 3): 1 July 1963 to June 1967. Quarry Heights, Canal Zone: Author, 1967.

U.S. Army School of the Americas. Academic Evaluation Reports: Colombia. Fort Benning, Georgia: Author, 1946-1970.

U.S. Army Special Warfare Center. Visit to Colombia, South America, by a Team from Special Warfare Center, Fort Bragg, North Carolina. Fort Bragg, North Carolina: Author, 26 February 1962.

U.S. Congress. House. Committee on Government Operations. U.S. Aid Operations in Latin America under the Alliance for Progress, Hearings before a Subcommittee of the House Committee on Government Operations, 90th Cong., 2d Sess., 1968. 
U.S. Congress. House. Foreign Affairs Committee. Hearings on Foreign Operations Appropriations for 1965. Part II, 88th Cong., 2d Sess., 1963.

U.S. Congress. House. Report of the Committee on Foreign Affairs. Special Study Mission to Latin America: Peru, Ecuador, Colombia, Panama, Costa Rica. 88th Cong., 1st Sess., 1963.

U.S. Congress. Senate. Committee on Foreign Affairs. Survey of the Alliance for Progress, Hearings before the Subcommittee on American Republics of the Senate Committee on Foreign Affairs, goth Cong., 2d Sess., 1968.

U.S. Congress. Senate. Committee on Foreign Relations. Survey of the Alliance for Progress - The Latin American Military, by Edwin Lieuwen. Washington, D.C.: U.S. Government Printing office, 1967.

U.S. Congress. Senate. Committee on Foreign Relations. Survey of the Alliance for Progress - Insurgency in Latin America, by David D. Burks. Washington, D.C.: U.S. Government Printing Office, 1968.

U.S. Congress. Senate. Committee on Foreign Relations. Survey of the Alliance for Progress: Colombia-A Case History of U.S. AID. 9lst Cong., Tst Sess., 1969.

U.S. Congress. Senate. Committee on Foreign Relations. U.S. Military Policies and Programs in Latin America, Hearings before the Subcomittee on Western Hemisphere Affairs of the Committee on Foreign Relations. 91st Cong., Tst Sess., 1969.

U.S. Congress. Senate. Report of the Comittee on Foreign Relations and the Committee on Armed Services. The Mutual Security Act of 1951. 82d Cong., 1st Sess., 1951.

U.S. Department of Commerce. Office of Technical Service, Joint Publications Research Service. Civic Action in Colombia. Washington, D.C.: U.S. Government Printing Office, 1962.

U.S. Department of Defense. "Civic Action: The Military Role in Nation Building." For Commanders 3 (15 January 1964): 1-4.

U.S. Department of Defense Security Assistance Agency. Fiscal Year Series. Washington, D.C.: Data Management Division, Comptroller, DSAA, 30 September 1984.

U.S. Joint Chiefs of Staff. Dictionary of United States Military Terms of Joint Usage, JCS Pub. 1. Washington, D.C.: U.S. Government Printing Office, August 1968. 
U.S. President. Committee to Study the United States Military Assistance Programs. Conclusions Concerning the Mutual Security Program. Washington, D.C.: U.S. Government Printing Office, June 1959 .

U.S. President. Committee to Study the United States Military Assistance Programs. Supplement to the Composite Report, vol. 2. Washington, D.C.: U.S. Government Printing Office, June 1959.

U.S. Southern Command. Civic Action Projects Reports: July-December 1964. Quarry Heights, Canal Zone: Author, n.d.

U.S. Southern Cormand. Civic Action Projects Reports: 1 March 19641 January 1965. Quarry Heights, Canal Zone: Author, 11 March 1965.

U.S. Southern Command. Civic Action Narrative Report: Colombia. Quarry Heights, Canal Zone: Author, 1969.

U.S. State Department. The Department of State Bulletin 21 (26 September 1949): 479-482.

U.S. State Department. Foreign Relations of the United States-The Amreican Republics, vol. 5. Washington, D.C.: U.S. Government Printing Office, 1961 .

U.S. State Department. Foreign Relations of the United States - The American Republics, vol. 7. Washington, D.C.: U.S. Government Printing Office, 1967.

Urquidi, Victor L. "Two Years of the Alliance for Progress." InterAmerican Economic Affairs 17 (Spring 1964): 21-35.

Urrutia, Miguel. The Development of the Colombian Labor Movement. New Haven, Connecticut: Yale University Press, 1969.

Van Cleve, John Vickrey. "The Political Use of Military Aid: The United States and the Latin American Military, 1945-1965." Ph.D. dissertation, University of California, Los Angeles, 1976.

Vidal, Ernesto. El "Plan Simpatico" en Colombia. Bogota: Ediciones M.R.B., 1966 .

Walterhouse, Harry F. "Civic Action: A Counter and Cure for Insurgency." Military Review 42 (August 1962): 47-54.

Walterhouse, Harry F. A Time to Build: Military Civic Action-Medium for Economic Development and Social Reform. Columbia, South Carolina: University of South Carolina Press, 1964. 
Walterhouse, Harry F. "Good Neighbors in Uniform." Military Review 45 (February 1965): 10-18.

Walton, John. Reluctant Rebels: Comparative Studies of Revolution and Underdevelopment. New York: Columbia University Press, T984.

Weinert, Richard S. "Violence in Pre-Modern Societies: Rural Colombia." The American Political Science Review 60 (June 1966): 340-347.

Williams, Samuel T. "The Practical Demands of MAAG." Military Review 41 (JuTy 1961): 2-14.

Williamson, Robert $C$. "Toward a Theory of Political Violence: The Case of Rural Colombia." Western Political Quarterly 18 (March 1965): 35-44.

Windle, Charles, and Vallance, T. R. "Optimizing Military Assistance Training." World Politics 15 (October 1962): 91-107.

Wolf, Charles, Jr. "The Political Effects of Military Programs: Some Indications from Latin America." Orbis 8 (Winter 1965): 871-893.

Wolpin, Miles D. Military Aid and Counterrevolution in the Third . World. Lexington, Massachusetts: D.C. Heath and Company, 1972.

Yarborough, William P. "The Special Warfare Center." Army 13 (November 1962): 62-63.

Zook, David H., Jr. "United States Military Assistance to Latin America." Air University Review 14 (September-October 1963): 82-85. 


\section{[PIl Redacted] BIOGRAPHICAL SKETCH}

David Edison Malott was

After completing his work at Wahtonka High School, The Dalles, Oregon, in 1972, he entered Oregon State University. Here he received the degree of Bachelor of Science in history and military science in 1976 and was commissioned a Second Lieutenant in the United States Army. His military career experiences include a three-year tour with the lst Infantry Division (Forward) in Germany, as a field artillery forward observer, fire direction officer, and firing battery executive officer; and a three-year tour at Fort Bragg, North Carolina, with the 82d Airborne Division, as a battalion intelligence officer, firing battery commander, and brigade fire support officer. He is also a graduate of the Field Artillery Officer Advanced Course, the Foreign Area Officer Course, and the Psychological Operations Officer Course. From May 1984 to August 1985 he pursued his work toward the Master of Arts degree under the United States Army Foreign Area Officer training program.

[PII Redacted Captain Malott is married to the former

[Pll Redacted] 
I certify that I have read this study and that in my opinion it conforms to acceptable standards of scholarly presentation and is fully adequate, in scope and quality, as a thesis for the degree of Master of Arts.

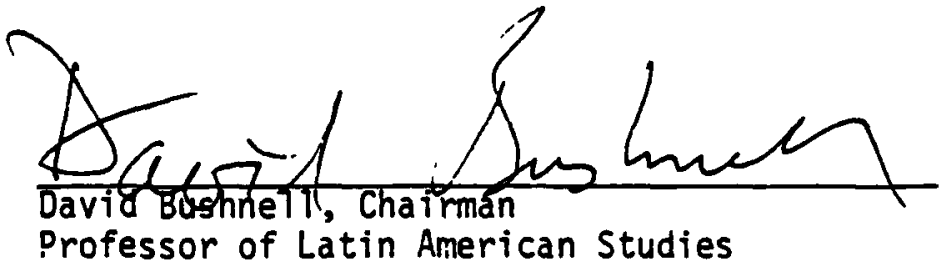

I certify that I have read this study and that in my opinion it conforms to acceptable standards of scholarly presentation and is fully adequate, in scope and quality, as a thesis for the degree of Master of Arts.

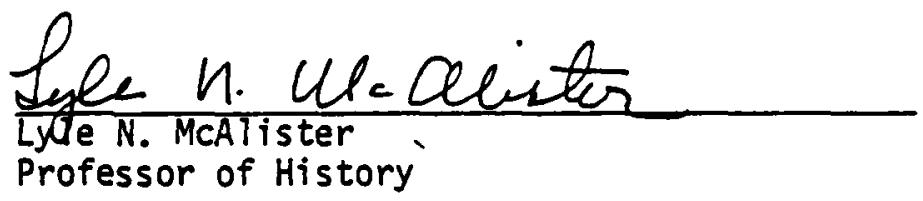

I certify that I have read this study and that in my opinion it conforms to acceptable standards of scholarly presentation and is fully adequate, in scope and quality, as a thesis for the degree of Master of Arts.

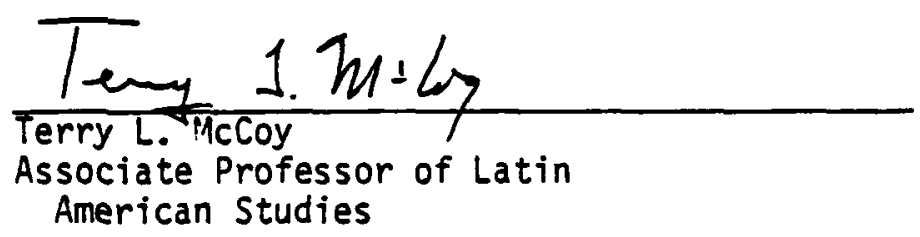

This thesis was submitted to the Graduate Faculty of the Center for Latin American Studies, to the College of Liberal Arts and Sciences, and to the Graduate School and was accepted as partial fulfillment of the requirements for the degree of Master of Arts.

August 1985

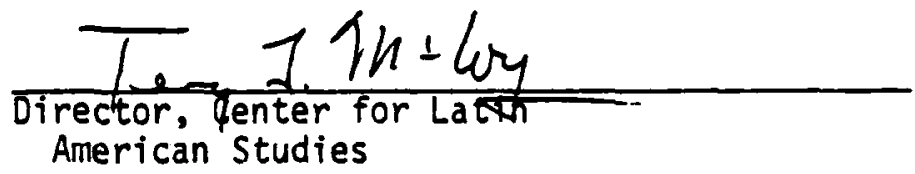

Dean, Graduate School 